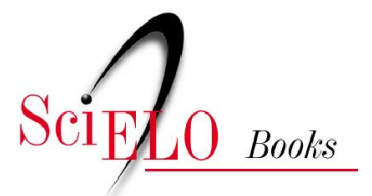

\title{
Judaísmo para todos
}

\author{
Bernardo Sorj
}

SORJ, B. Judaísmo para todos [online]. Rio de Janeiro: Centro Edelstein de Pesquisas Sociais, 2011, 116p. ISBN: 978-85-7982-056-4. Available from SciELO Books $<$ http://books.scielo.org $>$.

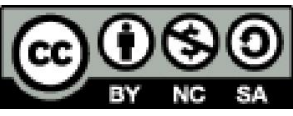

All the contents of this chapter, except where otherwise noted, is licensed under a Creative Commons Attribution-Non Commercial-ShareAlike 3.0 Unported.

Todo o conteúdo deste capítulo, exceto quando houver ressalva, é publicado sob a licença Creative Commons Atribuição Uso Não Comercial - Partilha nos Mesmos Termos 3.0 Não adaptada.

Todo el contenido de este capítulo, excepto donde se indique lo contrario, está bajo licencia de la licencia Creative Commons Reconocimento-NoComercial-CompartirIgual 3.0 Unported. 


\section{BIBLIOTECA VIRTUAL DE CIÊNCIAS HUMANAS}

JUDAÍSMO PARA TODOS

\section{Bernardo Sorj}

centro edelstein de pesquisas sociais
www.centroedelstein.org.br 


\author{
Bernardo Sorj
}

\title{
Judaísmo para todos
}

Esta publicación es parte de la Biblioteca Virtual de Ciencias Humanas del Centro Edelstein de investigaciones Sociales - www.bvce.org

Copyright (c) 2011 Bernardo Sorj

Copyright (c) 2011 de esta edición on-line: Centro Edelstein de Investigaciones Sociales

Ano da última edição: 2009, Siglo XXI Editora Iberoamericana, Buenos Aires, Argentina

Traducción del portugués por Jorge P. Aldrovani y Micheline Christophe:

Judaísmo para todos. Rio de Janeiro: Civilização Brasileira, 2010.

Ninguna parte de esta publicación puede ser reproducida o transmitida por cualquier medio de comunicación para uso comercial sin el permiso escrito de los propietarios de los derechos de autor. La publicación en su conjunto o en parte puede ser reproducida para fines no comerciales a condición de que el origen de la publicación y autor sea debidamente reconocida.

ISBN: $978-85-7982-056-4$

Rio de Janeiro

$$
2011
$$

centro edelstein de pesquisas sociais www.centroedelstein.org.br
Centro Edelstein de Investigaciones Sociales

www.centroedelstein.org.br/espanol/index.asp

Rua Visconde de Pirajá, 330/1205

Ipanema - Rio de Janeiro - RJ

CEP: 22410-000. Brasil

Contacto: bvce@centroedelstein.org.br 


\section{Índice}

Agradecimientos. ..$I I$

Introducción ..... ..$I I I$

Primera parte: Una cultura en mutación ..............................................1

Qué son los judíos .............................................................................2

El judaísmo bíblico......................................................................5

El período greco-romano y las variedades de judaísmo........................12

El judaísmo talmúdico.................................................................... 17

El mundo talmúdico en la Edad Media .................................................26

Judíos, cristianos y musulmanes ..........................................................34

La modernidad: el retorno de la filosofía, de la historia y de la política.38

Las corrientes del judaísmo moderno..................................................45

\section{Segunda parte: El judaísmo contemporáneo} .53

Holocausto, memoria y política........................................................54

El Estado de Israel.............................................................................58

Pos-modernidad, diáspora e individuación del judaísmo .........................68

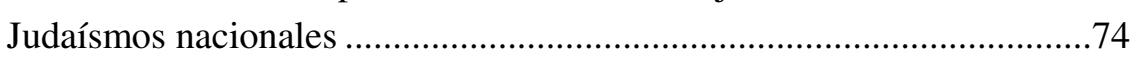

Judaísmo como resistencia, disonancia cognitiva y culpa colectiva .......77

Tercera parte: Desafíos y futuro del judaísmo .81

¿Quién habla en nombre de los judíos: ¿Rabinos? ¿Plutócratas? ¿Gobiernos de Israel? .82

¿Quién es judío?: casamientos y entierros ..........................................87

Antisemitismo y las relaciones Ydn y Goym.......................................91

El futuro del judaísmo ....................................................................97

El futuro del judaísmo secular....................................................100

ANEXOS: Textos sobre Pesaj y Yom Kippur..

110

\section{Agradecimientos}

El judaísmo como problema existencial y fuente de reflexión me acompañó durante toda mi vida. En este largo camino tuve la suerte de convivir con gran número de personas, sin las cuales este libro no existiría. No pudiendo nombrarlas a todas y seguramente mi memoria fallaría, solo puedo señalar algunos marcos sociales en los cuales me encontré con buena parte de ellos: el movimiento IMI, una invención latinoamericana de los años '60 que intentó la síntesis del sionismo y el espíritu revolucionario de la época; el grupo pacifista estudiantil IESH, que movilizó árabes y judíos israelíes, emigrantes latinoamericanos y europeos, y que en 1972 salió victorioso en las elecciones del gremio estudiantil de la Universidad de Haifa, un evento quizás único en la historia de Israel; los profesores del curso de Historia de Israel en la Universidad de Haifa, quienes renovaron mi visión acerca de la historia judía; y el mundo académico en el que encontré a tantos colegas de gran calidad humana.

Este libro fue escrito gracias al apoyo que me brindó el Centro Edelstein de Investigaciones Sociales, y particularmente su presidente y amigo, Joel Edelstein. El intercambio de ideas con Salomón Wald, con una visión del judaísmo y del mundo bastante diferente a la mía, fue siempre fructífero, y el diálogo y amistad de varias décadas con el rabino Nilton Bonder, fueron muy importantes para elaborar mi visión del judaísmo. Finalmente, los comentarios detallados a un primer manuscrito realizados por Bila Sorj, ciertamente ayudaron a mejorar mucho el texto. 


\section{Introducción}

Este texto es un esfuerzo de actualizar el judaísmo secular y humanista, que en los tiempos modernos orientó a los mayores pensadores, científicos, artistas y activistas judíos, de Spinoza a Hanna Arendt, de Freud a Einstein, de Gershwin a Chagall, de Kafka a Roth, de Theodor Hertzl a Emma Goldman, de Isaac Deutscher a Amos Oz, así como a la gran mayoría de sus premios Nobel. Judíos, que no invocaban libros sagrados o mandamientos divinos para afirmar una identidad judaica, que se nutrieron de la historia y de la cultura judía, de sus dramas psíquicos y existenciales, de lazos particulares de solidaridad cuando los judíos son perseguidos, como de revuelta cuando los judíos actúan sin sensibilidad frente al sufrimiento de los otros.

Esta actualización se hace necesaria porque el judaísmo moderno, que fue la gran fuerza creadora en el judaísmo del siglo pasado, se encuentra en crisis. Aunque represente la tendencia mayoritaria en la diáspora y en Israel, tanto su voz como su presencia institucional están enormemente debilitadas.

La crisis del judaísmo moderno es producto de las enormes transformaciones que las comunidades judías y las sociedades sufrieron en décadas recientes. Se trata de un mundo pos-socialista y pos-sionista, donde la globalización, la diseminación del discurso de los derechos humanos y la aceptación del multiculturalismo, disminuyeron la conflictividad de la condición judía. Como toda crisis, ella pone al descubierto los problemas y contradicciones de las visiones de mundo que eran consideradas obvias en el pasado.

El judaísmo moderno enfatizó las dimensiones universalistas de la tradición judaica. Haciéndolo así, encubrió las tensiones entre lealtades particularistas y universalistas presentes en la vida de cualquier persona, y que sólo desaparecerán el día - si es que ese día sucederá - en que la humanidad se viva como una sola. Hasta ese momento, los círculos de lealtad y solidaridad serán diversos y a veces conflictivos, y nuestra identificación con el sufrimiento y las alegrías de las personas tendrá pesos diferentes de acuerdo con nuestras varias identidades, familiares, religiosas, locales, nacionales, étnicas. En lugar de esconder estas tensiones, es importante explicitarlas, entender cómo ellas se expresan y así procurar avanzar en dirección a una mayor capacidad de comprensión de nuestras propias contradicciones internas y de nuestra compleja inserción en el mundo.

La visión de la historia orientada por la creencia en el progreso de la humanidad se reveló errada, o por lo menos excesivamente optimista. Por largo tiempo, por lo menos, viviremos en un mundo donde los conflictos políticos, étnicos y religiosos estarán presentes. Este reconocimiento es fundamental para no asumir una visión del mundo que desconoce los riesgos potenciales que los judíos pueden correr. En caso contrario, estaremos equivocándonos por ingenuos y dejando el terreno de la lucha contra el racismo a aquellos que se alimentan de una visión xenofóbica que se presenta como "realista", y que alimenta de toda expresión, real y aparente, de antisemitismo.

No sólo la racionalidad no orienta los procesos históricos, como ella no es, ni podría ser, el único fundamento de la subjetividad y de la acción de los individuos. Sentimientos, sensibilidades y la búsqueda de transcendencia están presentes en todo comportamiento humano, religioso o no. Es sobre ellos que se construyen los lazos sociales y las identidades colectivas. No se trata de hacer una apología de las dimensiones no racionales de la vida humana, sino de reconocerlas, única forma de limitar conductas irracionales y destructivas de nuestra humanidad y movilizarlas al servicio de valores humanistas.

El viejo judaísmo secular pecó por exceso de confianza en la capacidad del conocimiento racional de dar respuestas a todos los problemas existenciales, desvalorizando el papel de los ritos y de las dimensiones subjetivas sobre las cuales se construyen los lazos sociales. En lugar de negar los aspectos no racionales del accionar humano debemos reconocerlos y domesticarlos, única forma limitar el retorno de lo reprimido a través de conductas destructivas.

Al enfatizar las dimensiones universales del judaísmo, el antiguo humanismo secular judaico terminó eclosionando la capacidad de autocomprensión y de justificación de la propia existencia de los judíos. Pues si los valores judíos son los mismos que los valores universales, ¿para qué mantener entonces una identidad judía? El humanismo secular judaico debe recuperar la capacidad de valorizar las particularidades de la tradición y de la historia judaica, sin caer en visiones aislantes y deshumanizadoras, construidas en el miedo y en la desconfianza de lo no judío. 
El reconocimiento de las fuerzas de continuidad, de los sentimientos particularistas y de nuestros límites de modelar el mundo debe estar asociado a una visión más humilde del papel de cada generación en la historia y en la sociedad. El judaísmo humanista secular sufrió crónicamente de hybris, de un sentimiento de omnipotencia que colocó la humanidad en el lugar de Dios, soñando que podría transformar el mundo a su voluntad. No es el caso. Si Dios está muerto y todo está permitido, es limitada nuestra capacidad de cambiar y comprender el mundo, ya que somos humanos y no dioses. Si las respuestas de la religión sobre el sentido del universo no nos satisfacen, no se trata de encontrar sustitutos seculares, sino de aprender a convivir con una condición humana que presenta enigmas insolubles. Obviamente este reconocimiento no justifica la resignación y constituye la única fuente de actitudes verdaderamente éticas, ya que estas se sostienen en convicciones personales de lo que es cierto o errado, sin ninguna garantía de éxito o de compensación futura, en este o en otro mundo.

Esta hybris en relación al mundo se expresó también en relación al propio judaísmo. Toda la tradición cultural religiosa fue despreciada, y, en el caso del sionismo, fue negada la riqueza de la vida en la diáspora y su papel en la sobrevivencia del judaísmo. Así, discrepando y criticando otras tendencias del judaísmo, no podemos dejar de reconocer la actualidad de muchas de sus contribuciones, leídas bajo un nuevo signo, aunque muchos de sus aspectos sean inaceptables para nosotros. En suma, debemos ser pluralistas, no como expresión de tolerancia frente a lo diferente, sino de reconocimiento de la parcialidad de cada visión del mundo y de la importancia de la diversidad.

A diferencia del judaísmo secular del siglo XX que se fundaba en certezas sobre el sentido de la vida y de la historia, los judíos seculares del siglo XXI valoran la incertidumbre como fuente de libertad y de compasión. Las certezas dividen y separan, en tanto que asumir las incertidumbres, dudas y temores frente a lo desconocido, el sufrimiento y la muerte, nos dan la debida proporción de la condición humana. Las religiones institucionalizadas reconocen que las dudas invaden inclusive a los creyentes más devotos. Pero para ellas las dudas son momentos de fragilidad y deben ser combatidas. Las personas seculares, de las más diversas tradiciones culturales, viven las dudas y las incertidumbres sobre el sentido de la vida no como una debilidad, sino como fuente de compasión y sensibilidad frente a la condición humana, que alimenta nuestra curiosidad y que nos lleva a permanecer abiertos a nuevas respuestas y a la valoración de otras culturas.

El ateísmo o agnosticismo en la modernidad es tanto un cuestionamiento más general sobre la existencia de Dios, como una discusión particular con un cierto Dios, aquel dado por la tradición de cada individuo. Cuando un judío se define como agnóstico o ateo, expresa tanto la influencia general del pensamiento y de los valores modernos que colocan en cuestión la existencia de Dios o de su asociación con un cierto formato dado por las religiones, como refleja un cuestionamiento particular, al interior del judaísmo, sobre la capacidad de la religión judaica de dar respuestas convincentes a la búsqueda del sentido de la vida en general y del judaísmo en particular.

El judaísmo secular se construyó inicialmente en oposición a una tradición religiosa que era vivida como opresiva y paralizante. Sin duda, un diagnóstico correcto en la época y no fue casual que los que lucharon en el levantamiento del Gueto de Varsovia, los constructores del Estado de Israel y los que desarrollaron la cultura idish, hayan sido, en su gran mayoría, judíos seculares que se oponían a la ortodoxia religiosa. En el mundo contemporáneo, sin embargo, junto con el renacimiento fundamentalista, dogmático y autoritario, surgen nuevas corrientes donde la religión asume tendencias renovadoras, con orientaciones profundamente humanistas.

El divisor central que se coloca hoy para el judaísmo no es si Dios existe o no, un tema de foro íntimo, sino cómo vivir la religión y su relación con la política. Una división que se da entre aquellos que aceptan una visión pluralista y aquellos que quieren establecer un monopolio en la definición de lo que sea judaísmo; entre aquellos que consideran que hombres y mujeres poseen los mismos derechos y aquellos que justifican una visión subalterna para la mujer o condenan el homosexualismo; entre aquellos que utilizan la religión para imponer sus verdades como absolutas y aquellos que creen en la democracia y separan la política del mundo de las creencias transcendentales. Así, la cuestión no es la existencia o no de Dios, pues el siglo XX nos enseñó que el ateísmo, también él, puede ser una ideología inquisidora y totalitaria, pero si, en nombre de Dios, o del ateísmo, alguien se considera con derecho de imponer a los otros sus creencias.

Lo que distingue un judío humanista de alguien que no lo es, por lo tanto, no es Dios, comer kasher o usar kipa. Ellos representan un divisor de 
aguas solamente en la medida en que son usados para descalificar el judaísmo del otro y disminuir su legitimidad en el espacio público. Lo que caracteriza al judío humanista es la orientación práctica de respeto y valoración de la dignidad humana de todas las personas y pueblos, no permitiendo que las creencias o sentimientos de identidad colectiva deshumanicen aquellos que no participan de ellas. En este sentido, el judaísmo humanista es un esfuerzo constante de reinterpretar la tradición para que ella pueda ser parte, y no obstáculo, de la lucha por la dignidad de todo ser humano.

Por todas estas razones, el judaísmo humanista secular, en este siglo XXI, debe estar profundamente asociado a la defensa de la democracia. La libertad de conciencia, el respeto a la dignidad de todo ser humano, la justicia social, son valores fundamentales pero que pueden volverse retórica si no se encuentran anclados en instituciones que los aseguren y permitan la lucha constante por la preservación y ampliación del derecho a luchar por derechos. La democracia es fundamental para el Estado de Israel y es la única salvaguardia para que los judíos en la diáspora podamos desarrollarnos en paz y dignidad. Ella debe ser el modelo de la organización de las comunidades judías. Solamente el diálogo, el respeto y la capacidad de convivencia con las tensiones que naturalmente genera la diversidad de corrientes dentro del judaísmo pueden mantener la unidad dentro de la diversidad.

En la últimas décadas, los cambios dentro del judaísmo se han acelerado, produciendo inseguridad en muchas instituciones judías, llevándolas muchas veces al enclaustramiento y al alejamiento de las voces disonantes. Como planteó Albert Hirschman, cuando las organizaciones de las cuales somos parte nos dejan descontentos, nuestra primera reacción es expresar nuestra insatisfacción, usar nuestra voz. Pero la disposición a protestar depende del grado de lealtad, de nuestra voluntad de no abandonar el barco. En la medida en que nuestra voz no es oída, nuestra lealtad disminuye, y muchos optan por la salida. El autor de este libro, aunque respete esta opción, cree que ella puede ser tanto empobrecedora - pues implica el alejamiento de una tradición enriquecedora - como innecesaria.

Buena parte de los nuevos vientos en el judaísmo, a pesar de de la neblina generada por instituciones oficiales, sopla en el sentido de la renovación, y los judíos, en su gran mayoría, cada vez más se orientan hacia un judaísmo sin miedo de abrirse al mundo. En forma creciente están surgiendo nuevas formas de judaísmo que rompen con los modelos de la tradición, religiosa o secular, respondiendo a los desafíos de los tiempos actuales. El judaísmo hoy es extremadamente diverso y rico, aunque buena parte de esta diversidad sea desconocida inclusive por la mayoría de los judíos. En general, se trata de un judaísmo muy diferente de aquel de nuestros antepasados, abierto al mundo, no fundado en el miedo a la persecución, sino en el orgullo de ser parte de una cultura y una historia con enormes activos, que se enriquece en el intercambio entre $y d n$ (judíos) y goym (no judíos), en lugar de excluirse y aislarse.

Como toda identidad cultural, el judaísmo es una mezcla de destino y opción. Durante casi dos mil años, las circunstancias históricas llevaron a que ser judío fuese vivido como un destino. Cada vez más es una opción. Opción de ser judío y opción de cómo serlo. De nacer judío y querer continuar siéndolo. De ser judío y querer que los hijos también lo sean. De no nacer judío y disponerse a compartir la vida con judíos y tener hijos judíos.

Nuestra percepción de la realidad se da a través de conceptos que delimitan tanto el objeto como el valor que le otorgamos. Luchar por cambiar el mundo, tanto el personal como la sociedad, implica en un esfuerzo constante para percibir el mundo en forma diferente, esto es, dar nuevos significados a viejos sentimientos y conceptos y, si necesario, crear nuevos. El sentido último de la libertad como derecho inajenable es la posibilidad de cada individuo elaborar autónomamente su propia percepción de la realidad y colocarla en debate en el espacio público. Y esto incluye lo que es ser judío y el sentido del judaísmo.

El judaísmo sobrevivió por la capacidad constante de renovarse y adaptarse a las nuevas circunstancias. Espero que este libro contribuya a identificar estas nuevas tendencias y promover una visión pluralista del judaísmo. Toda respuesta a preguntas como “¿Quién soy/somos? ¿Qué camino debo/debemos seguir?" estará siempre repleta de tensiones y contradicciones. Nosotros, individuos y grupos sociales, somos vectores de deseos y valores contradictorios. El discurso intelectual tiende a crear la ilusión de que es posible ser coherente, cuando nuestra experiencia nos enseña que la realización absoluta de un valor puede significar abdicar o anular otros valores igualmente importantes. Individualismo y solidaridad muchas veces entran en choque, así como valores particularistas y universalistas. Vivir en libertad significa no sólo la posibilidad de elegir sino también de reconocer que toda elección implica conciliar valores 
diferentes en un esfuerzo permanente de dosificación y creatividad. Y, para aquellos que buscan respuestas en el judaísmo, recordar que el problema no es lo que es ser judío - ya que el judaísmo es múltiplo- pero elegir el judío que se quiere ser.

\section{PRIMERA PARTE:}

UNA CULTURA EN MUTACIÓN 


\section{QUÉ SON LOS JUDÍOS}

$\mathrm{P}$ ara definir algo o alguien usamos sistemas clasificatorios, esto es, conceptos que nos permiten identificar una entidad como parte de un conjunto de fenómenos similares y diferenciarla del resto. Por nuestra propia experiencia, sabemos que todos los sistemas de clasificación son limitados, a nadie le gusta ser "encuadrado", pues cada realidad individual es multifacética y está en constante mutación. También sabemos que conceptos generales esconden una enorme variedad de características y que, si bien son necesarios, son particularmente estrechos para pensar los grandes fenómenos culturales. Más aún, las nociones que movilizamos para entender la realidad son tomadas de la cultura en la cual vivimos, que transforma en "naturales" percepciones asociadas a nuestro contexto cultural, que dificultan nuestra capacidad de comprender otras formas de vivenciar e interpretar la vida social. Así, por ejemplo, el concepto de religión es asociado a la forma concreta que asume la religión dominante en la sociedad, y otras formas de religión son inimaginables y/o desdeñadas.

En el caso del judaísmo, lo caracterizamos generalmente como religión, pueblo, etnia o identidad colectiva. ¿Por qué esta variedad de definiciones? Porque son los conceptos que la cultura dominante nos ofrece, siendo que cada una de esas definiciones enfatiza una dimensión especifica de lo que sea la "esencia" del judaísmo. Pero el problema es que ninguna definición es suficiente para delimitar en la práctica la riqueza de la condición y de la cultura judía, cuya realidad efectiva se aproxima más a la imagen de una cebolla constituida por sus diversas capas, que a la de una fruta con un núcleo en el centro. Veamos si no: un judío religioso ultraortodoxo continúa considerando judío alguien que se define como ateo y anti-religioso, o aún mismo si él se convirtiese a otra religión, en caso que haya nacido de madre judía o se haya convertido al judaísmo. A su vez, gran parte de los judíos que no se consideran religiosos participan, en mayor o menor medida, de ritos y ceremonias con contenidos u orígenes religiosos. El Estado de Israel define como judío, con derecho a recibir la ciudadanía si vive en el país, una persona con un abuelo judío, en tanto que el establishment religioso local, que certifica quién es judío, sólo acepta como tal aquellos que nacieron de madre judía o los convertidos de acuerdo con sus reglas.
En suma, el judaísmo, en la práctica, es una identidad inherentemente plural $y$, siendo varias cosas al mismo tiempo, no se encuadra dentro de sistemas clasificatorios rígidos y unívocos. Para superar esta limitación, algunos autores procuraron conceptos más generales, como civilización judaica, cultura judaica o aún tribu o familia. Cualquier categoría, cuanto más amplia mejor, puede ser útil con la condición de no olvidar que cada vez que procuramos encontrar un concepto que defina lo que sea judaísmo, lo que estamos haciendo de hecho es enfatizar algún aspecto específico que valoramos más. A pesar de la definición dada por cada grupo o individuo, el judaísmo en la vida de las personas es una construcción en constante (re)definición, constituida por múltiples emociones y sensibilidades, donde, de alguna forma, estarán presentes los más variados componentes de la experiencia individual, de los padres, abuelos, el esposo o la esposa, y, por extensión, la cultura y psicología de una entidad que posee tres mil años de historia. Las formas en que ellas permean la vida de cada judío son variadas y personales y cambian en el devenir del contexto biográfico y las transformaciones de la sociedad.

El judaísmo por lo tanto es un sentimiento, una experiencia emocional de identificación con un universo psicológico y cultural que huye a las definiciones, pero dentro del cual se incluyen todos aquellos que de una forma u otra se sienten identificados con él. Esto es así porque el judaísmo moderno se fragmentó y todos los fragmentos forman parte del judaísmo.

Las identidades judías en la modernidad son múltiples. Así, la unidad del judaísmo no puede ser dada por una única corriente que se superpone a las otras, sino por el reconocimiento de la contribución de cada fragmento a la vida judaica, aunque muchas veces parte de lo que el otro cree o practique hiera nuestra sensibilidad. En lugar de preocuparnos con la fragmentación del judaísmo debemos celebrarla, pues es ella que genera la riqueza y vitalidad de un pequeño grupo formado por 13 millones de personas. Lo que no significa que debemos evadir las tensiones y la confrontación de ideas, pues ellas son fundamentales para el autoesclarecimiento y - ¿por qué no? - el proselitismo a favor de cada posición, pero sin procurar querer retirar del otro la legitimidad de su forma de expresar su judaísmo.

Como se construyó este mosaico de vivencias de ser judío pasa por los tres mil años de historia que desembocan en la diversidad contemporánea de 
expresiones individuales y colectivas de ser judío. Aunque cualquier ambición de síntesis de la historia judía huya de este ensayo, para entender dónde nos encontramos debemos referirnos, aunque de forma resumida, a los diversos períodos históricos en que se cristalizaron modelos variados de judaísmo. Estos modelos, en general de forma inconsciente, continúan actuando en el presente y se expresan en una miríada de sentimientos, prácticas y discursos que asocian los individuos al judaísmo.

Para cambiar el presente debemos entender el pasado, pues él muestra que lo que hoy aparece como formas naturales de ser judío son producto de decisiones tomadas en circunstancias históricas específicas. Y, por lo tanto, pueden ser cambiadas.

\section{EL JUDAÍSMO BÍBLICO}

I a Biblia es el texto de referencia de los judíos, independientemente de la importancia que a ella pueda ser dada, de la creencia en la veracidad o no de sus relatos o aún del hecho de que haya sido leída, pues en ella se encuentran los mitos fundadores que en el imaginario colectivo hacen de un individuo concreto, parte de una comunidad fundada en la historia. La Biblia define una filiación, relatos y arquetipos de un origen común presentes en el imaginario de judíos y no judíos, en particular la historia de Abraham abandonando su hogar y tierra natal para crear un nuevo pueblo, de la salida de la esclavitud de Egipto liderada por Moisés y del reino de Israel consolidado por David, a partir de las cuales se desenvolvieron tres mil años de historia.

Entendamos bien. Se trata de una forma posible de leer la Biblia. Ella fue resinificada por otras religiones y también puede ser analizada como obra literaria o histórica. Pero, en relación a los judíos, es un libro que cuenta el comienzo de la saga de un grupo que desemboca por los caminos más diversos en la vida de las personas que hoy se definen como judías. Inclusive, como veremos, el hecho de que las otras dos grandes religiones monoteístas, el cristianismo y el islamismo, hayan dado a este relato un significado diferente, es parte constitutiva del contexto cultural dentro del cual la cultura judía se constituyó y se constituye hasta los días de hoy.

En el transcurso del relato bíblico Dios se presenta con varios nombres - posiblemente expresión de las divinidades de las diversas tribus -, inclusive el de Elohim, dioses en plural. En la Torah, el Dios de los judíos entra en conflicto con otros dioses locales y hasta incluso es mencionado el culto por los israelitas a la diosa Ashera y sacrificios para Azazel.

Constituida por tres partes con un total de 24 libros, la Biblia o TaNaJ (Torah - Pentateuco; Nevihim - Profetas; y Ketuvim - Escrituras) entrelaza historias individuales y colectivas, creencias y legislación, y sobre todo, relata el curso de la alianza de un pueblo con Dios, en el cual va mudando la representación de Dios, del pueblo y de la alianza.

La versión canonizada de la Biblia fue consolidada durante el dominio persa, posiblemente en el siglo V o IV A. C., y en ella se superponen textos 
de varios períodos. El texto bíblico refleja autores diversos que expresan creencias e intereses diferentes, como de los sacerdotes, de la monarquía y de críticos de ambos. Como en una película que fue rodada en diferentes épocas y después editada sin considerar el momento de la filmación, la Biblia, por ejemplo, sitúa en la época de la salida de Egipto mandamientos que fueron elaborados mucho más tardíamente. Del examen filológico, que identifica la antigüedad relativa de las diferentes partes del texto bíblico, emerge un relato en el cual Israel fue evolucionando en las formas de representación de Dios - politeísmo, monoteísmo nacional que no excluía la existencia de otros dioses, monoteísmo exclusivo -, en los sentidos de su alianza con el pueblo de Israel y en la visión que los propios judíos tenían de su lugar en el mundo.

El primer conjunto de libros, la Torah (Pentateuco) relata en las primeras páginas la creación del mundo, de los seres vivos y del primer hombre y mujer (inclusive presentando dos versiones de este evento). Al principio es contada la historia de la "humanidad" en episodios cortos, relativos a los hijos de Adán, la construcción de la Torre de Babel y el diluvio. Después del diluvio, del cual sólo se salvan la familia de Noé y los animales que él llevó en el arca (y ciertamente los habitantes del mar), Dios realiza una alianza con la humanidad, por la cual él se compromete a no destruir a los seres vivos, exigiendo como contrapartida los llamados mandamientos Noahicos, que incluyen la prohibición de matar.

El resto de la Torah presenta el recorrido y los percances de la relación entre Dios y los judíos. Se inicia con la salida de Abraham de la casa de los padres hacia una tierra distante y su disposición a sacrificar el hijo Isaac por orden divina. En el último momento Dios manda sustituir el sacrificio por un cordero y la circuncisión pasa a ser la señal de la alianza con Abraham y sus descendientes, a quienes Dios promete la tierra de Canaán y una prole numerosa.

La historia de Abraham es seguida por la saga de sus hijo Isaac y el nieto Jacobo (que recibe el nombre de Israel), cuyos doce hijos darán origen a las doce tribus (pues los hijos de José darán lugar a dos tribus, Efraim y Menashe, y la hija Dina no producirá una tribu ya que la Biblia es patrilineal). La falta de alimentos en Israel lleva a Jacobo y sus hijos a Egipto, donde posteriormente serán esclavizados, dando comienzo a una nueva etapa de su historia.
En Egipto, Moisés lidera a los judíos hacia la libertad (que de acuerdo con la Biblia salen acompañados por otros pueblos) y promulga la legislación que será la nueva base de la alianza con Dios. El pueblo de Israel se compromete a cumplir los mandamientos divinos, y Dios, a protegerlo (y castigarlo en casos de no cumplimiento). Los mandamientos asociados a Moisés incluyen los sacrificios que deben ser ofrecidos a Dios y que aseguran el sustento de los sacerdotes, los asociados a la separación de lo puro y de lo impuro, en particular leyes dietéticas, pero también de vestimenta, la prohibición de contacto con ciertos tipos de enfermedades, mujeres menstruadas y muertos y leyes sobre el descanso de la tierra. Las leyes relativas a las relaciones sexuales, al incesto y al no desperdicio del semen (la prohibición de la masturbación, homosexualismo, zoofilia) posiblemente están ligadas a la preocupación con la expansión de la población y con la diferenciación en relación a prácticas aceptadas en otras culturas de la región.

Leyes que separan relaciones y actos sociales entre puros e impuros, ya sean dietéticas, indumentarias o de casamientos intrafamiliares, existen en todas las culturas, y ciertamente las de la Biblia se nutren - y a veces procuran diferenciarse - de tradiciones de la región. El esfuerzo central del texto bíblico es en el sentido de alejamiento de los ritos de fertilidad y culto a las fuerzas de la naturaleza de los pueblos vecinos, aunque él nunca sea completo. Las festividades bíblicas no dejan de mantener una fuerte relación con el ritmo de la vida de un pueblo agrícola.

La Torah instaura lo que quizá fue la principal contribución original de la cultura judía a la civilización humana, el Shabat, el día de descanso semanal. Otros mandamientos procuran asegurar un sistema de justicia imparcial, la liberación periódica de esclavos, el descanso de la tierra, el respeto por el extranjero, leyes sobre préstamos y formas de cosecha que aseguren que las sobras sean recogidas por los pobres.

En los libros de los profetas, el relato continúa con las vicisitudes de la ocupación de Canaán y las luchas contra los pueblos locales dirigidas por los jueces - líderes elegidos $a d$ hoc -, y el surgimiento de la monarquía. La monarquía en Israel está repleta de conflictos dinásticos que llevan a la división de las tribus de Israel en dos reinos, Judea - con Jerusalén como capital - e Israel - con capital en Samaria. Finalmente, relata la destrucción del reino de Samaria y su Templo por los asirios (722 A. C.), y del reino de 
Judea y su Templo por los babilonios (586 A. C.). El relato histórico finaliza con los eventos asociados a la reconstrucción del segundo Templo de Jerusalén, gracias al retorno a Jerusalén de miembros de la elite exiliada, con autorización del emperador persa Ciro, el Grande.

Junto con el relato histórico, aparecen las prédicas de los profetas. Tanto en los reinos de Judea y Samaria como en el exilio, los profetas ocupan un lugar central. Ellos amonestan a los reyes y al pueblo por desviarse de los mandamientos divinos, explican el pasado y prevén el futuro.

El gran desafío de los profetas fue explicar las derrotas, ocupación, exilio y destrucción de los reinos de Israel y Judea. Al final, la Biblia relata la historia de un pueblo pequeño que consigue enfrentar los enemigos más poderosos gracias a su alianza con Dios. ¿Qué habría sucedido con esta alianza? La respuesta de los profetas fue que el abandono de los mandamientos divinos por los reyes, y a veces también por el pueblo, habría llevado a Dios a retirar la protección a Israel. Los grandes imperios habrían sido instrumentos de Dios para castigar al pueblo judío. Pero el pacto de Israel con Dios seguiría vigente y finalmente, con la llegada del Mesías (el ungido), Israel volvería a recuperar su esplendor y ser or lagoim, luz para los pueblos.

El Mesías, en la tradición bíblica era alguien ungido con aceite como señal de elección divina, para cumplir una tarea especial, como fueron los sacerdotes, los jueces y los reyes. Los profetas dan a la llegada del Mesías un nuevo sentido, no sólo de líderes del pueblo sino de creadores de un nuevo tiempo de paz y prosperidad.

Así, los profetas inventaron la primera versión de la historia universal relatada desde el punto de vista de un pueblo pequeño y derrotado: la ascensión y caída de los imperios serían parte de la voluntad divina, la historia no sólo judía como la de los imperios estaría sometida a una lógica transcendental cuyo sentido final era dado por la llegada del Mesías.

Con los profetas, el judaísmo pasa de un monoteísmo nacional al monoteísmo universal. Con ellos se consolida la idea de pueblo elegido entre todos los pueblos. Pero la confirmación de esta elección, que se expresa en la protección divina, quedaría postergada para el día de la llegada del Mesías, introduciendo una nueva dimensión en el judaísmo, la esperanza mesiánica, que permite soportar el sufrimiento del presente en la expectativa de la redención colectiva futura.

La visión de los profetas transformó tanto la percepción de la historia como el papel de los grupos e individuos dentro de ella. En lugar de responsabilizar al destino, los dioses, o los enemigos por los acontecimientos sufridos, los profetas asociaron los traspiés de la historia a errores en la conducta moral. Crearon así la culpa individual y colectiva, que produjo tanto la interiorización de la responsabilidad moral como generó un sufrimiento enorme, producido por la omnipotencia de suponer que todo lo que acontece con los individuos y grupos es el resultado de sus actos.

El ethos de los profetas contiene fuertes componentes éticos y universalistas. Ellos no sólo denuncian el no cumplimiento de los mandamientos como critican la preocupación excesiva con los aspectos formales de la religión, como los sacrificios en el Templo, que pierden de vista el contenido. En algunos textos, la llegada del Mesías es presentada no solamente como la redención del pueblo judío, sino de toda la humanidad.

La Biblia nos ofrece una enorme variedad de dramas individuales y colectivos que permiten las interpretaciones más diversas, en la cuales es posible encontrar inspiración para diferentes ideales y valores. Ella contiene ejemplos de luchas por la liberación, como la salida de Egipto, leyes de justicia social y principios éticos, como "amarás al extranjero como a ti mismo", pero también orientaciones distantes de valores humanistas, en particular, las puniciones severas para los que se alejan de los mandamientos.

La fuerza de la Biblia, y también sus ambigüedades, se encuentra en el énfasis en los conflictos y debilidades de los seres humanos y las características humanas de Dios. Muchos lectores modernos tienen dificultad para aceptar como texto sagrado un libro en el cual Dios aparece como poseído no sólo por sentimientos de compasión y justicia, como de rabia y destrucción; donde se presentan historias poco edificantes, como las diez plagas sufridas por los egipcios, la total destrucción de la población de Jericó o de la familia de Koraj (que se opone a la decisión de Moisés de nombrar la familia de su hermano como la casta sacerdotal). La Torah posee principios morales y de justicia social que continúan actuales y otros que, si fuesen tomados al pie de la letra en una lectura fundamentalista, supondrían formas inaceptables de violencia, intolerancia y crueldad. 
En el texto bíblico se traslucen conflictos políticos y sociales, como entre aquellos que deseaban que las tribus fuesen unificadas por la unción de un rey y los opositores a la monarquía, incluyendo a Dios. Coloca en el origen del árbol genealógico del Rey David, a Ruth, que no sólo no es judía sino moabita, uno de los pueblos maldecidos en el Pentateuco. El Cántico de los Cánticos, un texto extremadamente sensual, o el Eclesiastés, un texto pesimista, y el libro de Job, una reflexión sobre el sufrimiento humano, dan a la Biblia una enorme versatilidad. Y muchas veces el discurso profético alcanza horizontes de universalidad que se extienden más allá de las tierras de Israel.

En el relato bíblico se presentan múltiples modelos de judaísmo y de ser judío: Abraham el negociador, pero también fanático a punto de disponerse a sacrificar su hijo; Moisés el estadista y legislador, pero que duda de sus habilidades para liderar su pueblo; Sansón, el héroe que defiende los israelitas con su vida, pero que se siente atraído por el mundo pagano, sus orgías y mujeres; David el pequeño guerrero que enfrenta el gigante Goliat y transforma Jerusalén en la capital, pero que también es atraído por la mujer de su general que él envía a la muerte en la guerra; Salomón el sabio cosmopolita, que expande su reino; en fin, los profetas con su radicalismo moral.

Yuxtaposición de varios relatos orales de épocas diferentes, elaborados durante un período de casi un milenio, la Biblia se presenta como un texto complejo, formado por varias capas e influencias diversas, versiones variadas y repetitivas de mandamientos y eventos. En lugar de un producto acabado y coherente, tenemos una trama que no constituye un tratado filosófico o una guía de principios éticos, si bien ellos pueden ser encontrados. Ella cuenta la historia de seres humanos y sus relaciones con Dios, con sus contradicciones, debilidades y grandezas, y de múltiples héroes y mandamientos que permitieron las más variadas lecturas y usos.

En esta complejidad se encuentra la fuerza y la fragilidad del relato bíblico. Como veremos, la diversidad de historias y de sentidos que pueden serle dados, las incongruencias, repeticiones, versiones no monoteístas de Dios, mandamientos poco específicos e historias de personajes centrales cuyas prácticas son distantes de los mandamientos divinos, constituyeron el sustrato a partir del cual las generaciones posteriores elaboraron diferentes interpretaciones para resolver las tensiones y contradicciones del texto original.
En buena medida, la historia del judaísmo es la de las relaciones complejas entre el texto original de la Biblia y sus interpretaciones. En la Biblia, aparecen los valores y los temas centrales dentro de los cuales el pueblo judío interpretará y dará sentido a su experiencia histórica: la tierra prometida, la alianza con Dios, Jerusalén, la diáspora, enemigos que buscan exterminar al pueblo de Israel, las divisiones internas, la dependencia de los cambios geopolíticos, el conflicto entre los intereses políticos y los religiosos, entre los mandamientos, como forma y como contenido, y la esperanza mesiánica. Pero, sobre todo, y esta será la marca más profunda de la Biblia sobre la psique colectiva de los judíos, presenta la historia de un pueblo minúsculo, localizado en el cruce entre Asia y África, en el corazón del mundo antiguo, destinado a ser destruido por el pasaje de los imperios, que se sobrepone a todos los percances y encuentra fuerzas para sobrevivir. Es esta obstinación en continuar existiendo a pesar de las señales contrarias dadas por la experiencia y por la historia que llevó a los profetas a transformar los imperios en instrumentos de Jehová y a creer que un día Israel volverá a ocupar su lugar de "luz para los pueblos". Esta capacidad de resistir, de resiliencia, permitió la propia existencia de la Biblia, quizás el documento más antiguo escrito por un pueblo que sobrevivió a múltiples derrotas y que consiguió contar su historia, cuando ésta siempre fue escrita e interpretada por los poderosos y victoriosos. 


\section{EL PERÍODO GRECO-ROMANO Y LAS VARIEDADES DE JUDAÍSMO}

1 pequeño espacio territorial y la aridez de la tierra de Israel hicieron con que parte de su población emigrase desde temprano, a lo que se agrega el exilio de las elites en Babilonia, después de la destrucción del primer Templo, ciudad que se transformará en un gran centro cultural judaico durante un milenio. De esta forma, antes de la destrucción del segundo Templo (70 D. C.) buena parte de los judíos ya vivía fuera de la tierra de Israel, cuya población fue radicalmente diezmada solamente después del levantamiento contra Adriano (132-135 D. C.). Señal de la importancia de la diáspora en la época de la destrucción del segundo Templo es el relato del historiador judío-romano Flavio Josefo sobre las expectativas de los grupos que se levantaron contra el imperio romano de que los judíos de la diáspora enviarían armas y apoyo.

Como indica Martin Buber en su libro Moisés, la característica central del judaísmo es la de ser un pueblo errante, absorbiendo constantemente elementos de la cultura exterior. Las influencias externas, al mismo tiempo que modifican la cultura judía, son transformadas, en el proceso de asimilación, dándoles nuevos significados. Buber muestra que prácticamente todos los elementos que están en la Biblia, comenzando por la lengua y escritura, se nutren de las culturas del Oriente Medio, de donde habrían sido tomados por los hebreos. Buber indica que la única contribución original del judaísmo bíblico habría sido la creación del sábado como día de descanso (que ya existía como día sagrado en Babilonia, pero celebrado con ritos de auto-punición y expiación).

La absorción de elementos de la cultura externa es un proceso lento que va permeando costumbres y actitudes cotidianas. Pero son las elites, responsables por la elaboración y codificación de la versión "oficial", quienes viven estas influencias externas como problemas que exigen respuestas intelectualizadas. Las diferentes interpretaciones generan guerras culturales en torno de cuál sea la "verdadera" tradición.

Las influencias externas son vividas de forma más dramática en contextos de apertura cultural, como son los tiempos modernos y como fue el período greco-romano. En los períodos en que la cultura externa se busca imponer por la fuerza o aislar la cultura dominada, es más simple cerrarse sobre sí mismo y mantener la tradición heredada. Pero cuando las influencias externas se dan a través de ejemplos y argumentos, la tradición entra en crisis y las elites se dividen sobre cómo integrar los nuevos aires del mundo.

Aunque toda comparación entre períodos históricos tenga sus obvias limitaciones, pues la historia nunca se repite, el período greco-romano tiene importantes similitudes con los tiempos modernos. Podríamos decir que fue la primera experiencia de "globalización" cultural, iniciada por Alejandro de Macedonia y consolidada por los siglos de Pax Romana. Hasta que el poder imperial romano transforma el cristianismo en religión de estado se constituyó un espacio que incluía todo el Mediterráneo y Oriente Medio, donde convivían, interactuaban e inter-influenciaban las más diversas tradiciones culturales, bajo la égida del helenismo. El resultado de esta experiencia fue el surgimiento de nuevas versiones sincréticas de viejas culturas y religiones, inclusive del judaísmo, y el surgimiento de nuevas religiones a partir de viejas culturas, como fue el cristianismo.

La cultura greco-romana se apoyaba en la filosofía griega y en el politeísmo abierto a las más diversas religiones y creencias, teniendo como epicentro la Polys. En ella se encontraban el lyceum, el teatro, el circo, el gymnasium y los baños, que irradiaban valores culturales y un estilo de vida. Estas influencias penetraron el judaísmo que se dividió en diferentes corrientes que se enfrentaban como partidos y movimientos sociales en el interior de la misma tradición.

Cada corriente dentro del judaísmo desarrolló su propia versión sincrética de la tradición bíblica, integrando las nuevas creencias y discursos de la época. Pero, no sólo el judaísmo se modificó, como también influenció la vida cultural del imperio romano. El judaísmo era, en la época, extremadamente exitoso en términos de proselitismo. Se calcula que en el imperio romano, en el período del segundo Templo, entre 5 y $10 \%$ de la población libre era judía o judaizante (personas identificadas con el judaísmo, pero que sólo circuncidaban sus hijos).

Con las conquistas de Alejandro Magno, la influencia helénica llegó a las elites de Jerusalén. El libro de los Macabeos menciona la apertura de un gymnsium por el sumo sacerdote. Pero, cuando en el año 167 A. C. el Rey Seleucida (una de las tres dinastías en que se dividió el imperio de Alejandro), 
Antíoco IV, comienza a perseguir la práctica del judaísmo e impone el culto de Zeus en el Templo de Jerusalén, explota una revuelta armada.

La revuelta, dirigida por el sacerdote Matatías y sus hijos de la familia de los Jashmonaím (conocidos como los Macabeos, por el nombre del principal líder, Judas Macabeo), derrota Antíoco y retoma Jerusalén y el Templo. El triunfo Macabeo fue posible por el declive interno del Imperio Seleucida y el vacío geopolítico de la región por los problemas que pasaban los otros reinos vecinos.

La victoria macabea dará lugar a la fiesta de Januka, donde se conmemora el milagro de una pequeña cantidad de óleo consagrado lograr iluminar durante ocho días la llama eterna del templo recién reconquistado. El símbolo de la fiesta es la Janukia (candelabro de ocho brazos), que junto con la Menorah de siete brazos, localizada en el templo, constituyen los principales símbolos judaicos, ya que la estrella de David sólo en época relativamente reciente fue asociada al judaísmo.

Los reyes macabeos (140 A. C. a 37 A. C.) conquistan nuevos territorios y convierten los pueblos sometidos, pero la expansión se detiene en las fronteras bíblicas correspondientes al reino de Israel en la época de Salomón. La dinastía Macabea rápidamente comienza a ser influida por la cultura helénica, y los últimos reyes asumen nombres griegos. Finalmente son derrotados por la nueva potencia del mundo mediterráneo, Roma, que pondrá fin, durante dos mil años, a la autonomía política de los judíos en la tierra de Israel.

En el reino Macabeo, y aún más en el período romano, las divisiones internas de Israel se multiplican. De acuerdo con Flavio Josefo, la intervención romana inclusive habría sido solicitada por judíos disidentes, insatisfechos con la helenización de los reyes macabeos. La principal división interna, en el período greco-romano, era entre Saduceos y Fariseos, que, en líneas generales, estaban asociados respectivamente a los sacerdotes y a las clases medias urbanas. Ambos compartían el desprecio por el pueblo campesino inculto (los am aharetz - literalmente pueblo de la tierra). Los Saduceos seguían la Biblia al pie de la letra, en tanto los Fariseos, fundadores del judaísmo rabínico que, como veremos, dará lugar al Talmud, apoyaban interpretaciones que iban mucho más allá de la versión literal del texto. Así, por ejemplo, los Saduceos apoyaban la aplicación de la Ley de Talión (ojo por ojo), en tanto los Fariseos proponían puniciones alternativas.
La lucha por la legitimidad de cada corriente se dio inicialmente en el interior del Sanhedrin (la suprema corte de justicia, dominada en el período Macabeo por los sacerdotes, pero de la cual también participaban sabios fariseos). Con el fin del segundo Templo, los Saduceos desaparecieron, y el Sanhedrin pasó a ser controlado por los Fariseos. A pesar de que los Saduceos (de los cuales sabemos poco y por fuentes que no les son favorables) tenían simpatía por el mundo helénico, se oponían a la creencia en la inmortalidad del alma individual y en la existencia de otro mundo, nociones que se habían popularizado por influencia externa, pero que no se sustentaban en el texto bíblico. Los Fariseos, por otro lado, aceptaron estas creencias y las integraron en el judaísmo, tornándose un componente central de la tradición talmúdica, que será discutida en el próximo capítulo.

Estas grandes corrientes coexistían con varias sectas, en general con características ascetas, como la de los Esenios, y con grupos nacionalistas militantes, en particular la de los Zelotes y los Sicarios, que lideraron el levantamiento contra Roma que culminó con la destrucción del segundo Templo.

Junto con estos grupos organizados, generalmente de origen urbano y cultos, la población pobre y no erudita (los am aharetz, "gente de la tierra"), sufriendo penurias y sofocada por los impuestos pagados a Roma, era constantemente movilizada por líderes carismáticos que se apoyaban en la esperanzas mesiánicas y en los vientos apocalípticos y místicos que asolaban la región. Uno de estos movimientos, parte del paisaje pluralista del judaísmo de la época, eran los cristianos, o Nazarenos, seguidores de Jesús de Nazaret.

La separación de los seguidores del Nazareno del judaísmo fue un proceso largo y complejo, en el cual Pablo tuvo un papel central. El alejamiento fue tanto práctico como teológico. Aún así el nuevo testamento mantiene la tradición farisea de legitimar su narrativa sustentándola en trechos del texto bíblico. Desde punto de vista práctico, el rompimiento se dio, de acuerdo con el Nuevo Testamento, en el Concilio de Jerusalén, cuando triunfa la posición de que los nuevos convertidos al cristianismo no deberían ser circuncidados. Desde el punto de vista teológico, en un proceso que se prolongará por siglos, el cristianismo integró componentes helénicos, gnósticos y zoroastras, enfatizando la lucha entre el bien y el mal, entre la 
carne y el espíritu, y sustituyendo la visión mesiánica judaica como redención colectiva por la salvación individual.

Durante el período greco-romano, el judaísmo desarrolló instituciones que representaban una alternativa al lyceum, como el Bet Kneset (literalmente casa de reunión, la sinagoga) y la Bet Midrash (literalmente casa de interpretación, el local de estudios). Aunque no exista información suficiente sobre sus formas iníciales, aparentemente el Bet Knestet surgió en el exilio babilónico, funcionando como sustituto del Templo. Era un local de oraciones, donde la Torah era leída los sábados, pero, como su nombre indica, era también un espacio de reunión. El Bet Midrash surgió en el período inmediatamente posterior a la destrucción del segundo Templo, como local de estudio e interpretación de la Biblia, y se transformó en el centro de producción de conocimiento y de formación de rabinos.

No sólo en Israel la influencia del mundo helénico modificó la visión de los judíos sobre sí mismos. En la diáspora, Filón de Alejandría, ciudad egipcia donde existía una gran comunidad judía, hizo una lectura de la Biblia a la luz de la filosofía griega, en particular del estoicismo. De la misma forma que los Fariseos, él valoró la interpretación frente al sentido literal del texto. Sólo que su interpretación de la Biblia siguió un camino distinto. Para Filón, Dios usó alegorías para comunicarse con los humanos y argumentó que estas alegorías pueden ser elaboradas dentro de las categorías de la filosofía griega.

El mundo greco-romano fue un mundo culturalmente abierto, que favoreció la diversidad, inclusive dentro del judaísmo, donde cada corriente combatía y/o interactuaba de forma abierta con las otras, influenciándose mutuamente. La tolerancia con la diversidad religiosa sólo acabó cuando el imperio romano abrazó el cristianismo. Pero a esa altura, el fariseísmo ya había avanzado mucho en la consolidación de la tradición que será dominante en el pueblo judío hasta la llegada de la modernidad, el judaísmo talmúdico.

\section{EL JUDAÍSMO TALMÚDICO}

Z 1 fariseísmo se transformó en la corriente dominante en el judaísmo, aunque las otras corrientes, como el saduceísmo, que resurgirá en la Edad Media en una versión nueva, la del caraísmo (grupo cuyos remanentes existen hasta hoy). que rechazan el Talmud como libro sagrado. Los seguidores de la filosofía griega (denominados por el Talmud como apikoires - literalmente seguidores del epicureísmo), estarán presentes implícita y explícitamente en el universo rabínico, como sus principales opositores junto con los caraítas. .

El triunfo del fariseísmo es muchas veces presentado como demostración de que el judaísmo rabínico era la única respuesta posible y auténtica del judaísmo. Se trata de una construcción a posteriori. El judaísmo fariseo triunfó gracias a una serie de circunstancias históricas ajenas al mismo. La destrucción del Templo eliminó la competencia de la casta sacerdotal, que poseía una legitimidad enorme que los propios fariseos nunca cuestionaron. La posterior transformación de los judíos en un pueblo diaspórico eliminó las masas de campesinos, los am haaretz, y urbanizó buena parte de los judíos. Pero, sobre todo, fue el triunfo del cristianismo, ya al final del período romano, el que aisló el judaísmo y creó las condiciones para la larga hegemonía de la interpretación farisea sobre el judaísmo. El aislamiento impuesto a partir del exterior vino al encuentro de la versión rabínica, que llevaba a los judíos a vivir en un mundo auto-referido. Cuando las barreras del mundo exterior comenzaron a desmoronarse, en los tiempos modernos, también comenzó a derrumbarse el judaísmo rabínico.

La principal obra de referencia del judaísmo rabínico es el Talmud, constituido por dos conjuntos de libros, la Mishna y la Guemara. En tanto la Mishna interpreta directamente el texto bíblico, la Guemara realiza esta interpretación apoyándose en la Mishna. La Mishna, escrita en hebraico, es formada por seis volúmenes recopilados en tormo del año 200 de la D. C., conteniendo la memoria de tradiciones trasmitidas oralmente por varios siglos. El segundo conjunto, la Guemara, tiene dos versiones, la de Jerusalén, concluida a fines del siglo IV de la D. C., y la Babilónica, completada a comienzos del siglo VI de la D. C., ambas escritas en versiones diferentes de arameo-hebraico. La versión babilónica de la Guemara es la prevaleciente. 
La legitimidad del texto talmúdico se construye en torno de la visión de que existen dos tipos de Torah, la Torah she ve ktav (la Torah escrita, el Pentateuco, en particular, y la Biblia, en general), y la Torah she ve al pe (la Torah oral), o sea, las interpretaciones posteriores al cerramiento del texto bíblico, particularmente los textos compilados por el Talmud.

La cuestión que se colocaba, y que hasta hoy continúa siendo el divisor central entre las diversas corrientes del judaísmo religioso, es cuál es la relación entre ambas versiones. $\mathrm{O}$, dicho de otra forma, ¿sobre qué bases se sustenta la legitimidad de la llamada versión oral, que en muchos aspectos expandió, modificó y añadió mandamientos a la legislación bíblica?

En el Talmud son presentadas tres versiones diferentes, siendo la premisa de todas ellas que la Torah (el Pentateuco) tiene origen divino y fue entregada por Dios a Moisés. Una versión es que no solamente la Torah fue entregada a Moisés, como también el conjunto de las interpretaciones posteriores, la Torah she ve al pe. Una segunda versión es que Dios entregó a Moisés las reglas de interpretación de la Torah escrita, a partir de las cuales los rabinos elaboraron la nueva Torah. Finalmente, una tercera versión, sobre la cual se construye de hecho buena parte de la argumentación talmúdica, es la búsqueda de relaciones entre el texto bíblico original y la nueva interpretación. A la pregunta: “¿cómo sabemos esto?”, o sea, la nueva interpretación, los rabinos responden apoyándose en un pasaje del texto bíblico, que sustentaría el argumento. Por un lado los rabinos expresan la confianza en la exactitud de sus interpretaciones del texto bíblico en narraciones donde Dios expresa su posición en controversias relacionadas a cuestiones de pureza/impureza y los rabinos deciden en oposición a la interpretación divina. Por otro lado el reconocimiento de la fragilidad de estas interpretaciones se expresa en la frase que todas las interpretaciones se sustentan en un cabello.

El Talmud, por lo tanto, se fundamenta en la interpretación (drash), en el arte de retirar del texto aquello que no aparece en una lectura literal (pshat). Para realizar esta interpretación del texto bíblico, los rabinos desarrollaron una serie de métodos de lectura. Estos métodos procuran inferir - por deducción, generalización y analogía - un sentido no aparente del texto bíblico. Como la suposición es de que la Torah representa la palabra divina, los rabinos usan las repeticiones, cierta verborragia del texto bíblico, letras intercaladas (en particular la letra vaf, que en general es usada como juntura equivalente a la letra y), y métodos de lectura que les permiten relacionar o fusionar palabras y frases, para presentar sus interpretaciones como deducidas del texto bíblico (por ejemplo, si un mandamiento aparece dos veces, se deduce que no es una simple repetición, pues Dios no habla en vano, indicando por lo tanto un nuevo sentido). En algunos casos, se reconoce que la interpretación se origina en la tradición y en la autoridad rabínica (mi-de-ravanam), sin fundamento en la Torah escrita. En este caso, el texto bíblico es considerado una simple asmajta, un apoyo para la regla, pero no su origen.

Muchas de las reglas del Talmud eran producto de tradiciones desarrolladas en la práctica ordinaria, pero en la elaboración rabínica ellas adquirían fuerza de ley como parte de un sistema prácticamente cerrado e inamovible. Sea legitimando tradiciones retiradas de las prácticas cotidianas, sea produciendo innovaciones imaginativas, los rabinos detallaron y expandieron mandamientos que en la Biblia aparecen como indicaciones poco específicas. Parte de la lógica de esta expansión era crear un "cerco al cerco". Esto es, asegurar que los mandamientos no fuesen transgredidos. Un ejemplo es el mandamiento que ordena no cocinar la cría en la leche de la madre. A partir de varios cercos a este mandamiento, se llega finalmente a la versión de que es prohibido comer cualquier comida láctea con carne, debiendo inclusive esperarse que finalice la digestión, para que no sean mezcladas en el estómago (la inclusión de las gallinas - animal que no produce leche - en la categoría "carnes", es una licencia rabínica). Desarrollos similares se dan en relación al Shabat, el día del descanso. La Torah prohíbe el trabajo físico, y los rabinos elaboraron el concepto de trabajo al punto de excluir cualquier esfuerzo físico, inclusive el de cargar cualquier peso fuera del hogar. Detalle y rigor similar fueron desarrollados en relación a los ritos y reglas de separación en relación a la mujer menstruada. En el caso de las bendiciones y oraciones a ser practicadas por cada individuo, prácticamente inexistentes en la Biblia, los rabinos transformaron casi todo acto cotidiano en razón para realizar una bendición, y orar tres veces al día pasó a ser obligatorio para los hombres.

A partir de algunas indicaciones muy generales de la Biblia, el Talmud elaboró buena parte del aparato simbólico y litúrgico que hoy identificamos con el judaísmo. Así, la forma de celebrar las fiestas judías, las oraciones, las bendiciones, los ritos de pasaje, el uso de filacterias o los criterios por los cuales se define quién es judío, remontan de hecho al Talmud. 
En lugar de principios jurídicos abstractos y generales, el Talmud, como buena parte de la legislación del Oriente Medio, se refiere a casos específicos, situaciones concretas a partir de las cuales la jurisprudencia más general es establecida. Los rabinos actualizaron y detallaron la legislación relativa a juicios, a derechos civiles y comerciales y reinterpretaron la Ley de Talión (ojo por ojo) permitiendo compensaciones materiales, en lugar de la punición física del agresor. Pero, si los rabinos actualizaron ciertas puniciones bíblicas, no abandonaron la idea de castigos rigurosos y una extrema intolerancia para los que no cumplen los mandamientos. Al contrario de la Biblia, las puniciones no sólo incluyen castigos en este mundo, sino la exclusión en el otro mundo y en el mundo por venir con la llegada del Mesías.

En suma, los rabinos ampliaron, radicalizaron e inventaron nuevos mandamientos que separan lo puro de lo impuro y las ceremonias religiosas. Muchas de las nuevas reglas sólo se aplicaban originalmente a los sacerdotes y otras fueron inspiradas en los servicios del Templo. Las oraciones diarias, que pasaron a ser obligatorias para todos los hombres, debían ser recitadas varias veces al día en los mismos horarios que en el Templo se realizaban las ceremonias de sacrificio. En el judaísmo rabínico, cada hogar fue transformado en un Templo, y cada judío un sacerdote, en términos de dedicación a las normas religiosas y de la preocupación constante de servir a Dios y mantener las reglas de pureza. La santificación de cada acto objetivaba crear lo que un autor denomina "misticismo cotidiano", transformando cada práctica cotidiana en una ceremonia de contacto con Dios.

El midrash halaja (interpretaciones relativas a los mandamientos) es sólo un componente del Talmud. Un segundo componente es el midrash hagada (interpretaciones narrativas) constituido por anécdotas, metáforas y cuentos que se refieren a pasajes del texto bíblico. En él se encuentra una diversidad de reflexiones: explicaciones sobre el sentido de trechos de la Biblia, justificaciones sobre el origen divino de la Torah escrita y oral, relatos sobre la historia de Israel y sobre la vida de los propios rabinos, interpretaciones de la intención divina, el mundo de los ángeles y a veces demonios, elucubraciones sobre la llegada de los tiempos mesiánicos y el destino de las tribus perdidas de Israel. Estas narrativas nutrieron durante siglos el imaginario judío, en particular de los menos cultos, que oían en la sinagogas las historias de cómo Dios castigaba a los emperadores que perseguían a los judíos, engrandecía los héroes bíblicos y los rabinos, hablaba de la llegada del Mesías y ofrecía lecciones de sabiduría práctica.

El mundo del midrash hagada es extremadamente rico e imaginativo, repleto de metáforas creativas y supersticiones anacrónicas, si tomadas al pie de la letra. En él conviven versiones de apertura para el mundo no judío, como una nueva versión de los mandamientos noahicos (que habrían sido dados por Dios a Noé), casi similar a los diez mandamientos y que serían válidos para toda la humanidad, y tendencias al auto-encerramiento y xenofobia. Esta riqueza de orientaciones, muchas de ellas contradictorias, hicieron del Midrash Hagada un importante recurso del imaginario popular.

Finalmente, se encuentra en el Talmud el Pirkei Avot (literalmente "capítulos de los padres", pero generalmente traducido como "ética de los padres") que recoge máximas de los rabinos. Se trata de un texto que se aproxima a una filosofía de vida, y, entre sus máximas, se encuentran las famosas frases de Hillel (siglo I A. C.): "Si yo no hago por mí mismo, ¿quién lo hará?, si yo no hago por los otros, ¿quién lo hará?; si no es ahora, ¿cuándo?", y "No hagas a los otros lo que no deseas que te hagan a ti" (En otra versión de la Mishna "lo que es odioso para ti no hagas a tu prójimo. Esta es la Torah. El resto es explicación. Va y estudia").

El universo del Talmud es distante de la cultura greco-romana y del cristianismo católico. El Talmud no posee una teología ni una serie de principios dogmáticos o un argumento filosófico sobre Dios. Para los rabinos, Dios está presente en el texto de la Torah, y la única forma de aproximación es a través de su estudio y de la comprensión del significado de cada palabra y frase y, sobre todo, practicando los mandamientos.

Igualmente, el Talmud no tiene ninguna preocupación filosófica con una visión antropomórfica de Dios, pues, finalmente, la Biblia declara que el hombre fue hecho a imagen de Él. En cierta medida, Atenas y Jerusalén son mundos aparte, lógica versus interpretación, coherencia del pensamiento individual versus profundización de la tradición colectiva, el mundo de la naturaleza a ser revelado versus el texto sagrado a ser profundizado, ética versus cumplimiento de los mandamientos.

No es que no se pueda deducir del texto talmúdico una ética o elementos de una teología, pero ellos no se presentan como tales. Aunque algunos mandamientos puedan hoy ser justificados como siendo 
"funcionales" o justificables científicamente, no son seguidos por su racionalidad. Así, por ejemplo, ciertas reglas dietéticas pueden ser justificadas como saludables, pero no por eso un judío ortodoxo considera que no comer alimentos con colesterol o hacer ejercicios diarios sean mandamientos divinos.

Al contrario de la filosofía aristotélica, donde la lógica impone que sólo una verdad o versión de la realidad sea finalmente la verdadera y excluyente de las otras, el universo talmúdico acepta que varias interpretaciones sean posibles. La Torah, siendo la palabra divina, nunca puede ser reducida a una única interpretación humana, por su propia naturaleza finita y parcial. El Talmud contiene siempre más de una interpretación para el mismo problema, generando debates y divisiones entre escuelas, sobre cuál interpretación debe ser seguida y un esfuerzo renovado en cada generación de lectura y comprensión.

Pero el Talmud también se aparta del universo bíblico, que se encuentra totalmente inmerso en la historia y en los eventos políticos, dentro de los cuales se inserta la alianza entre Dios y su pueblo. En el universo talmúdico la historia y la política son evacuadas. De acuerdo con el midrah hagada, con la destrucción del Templo, Dios se aparta de Israel y sólo retornará con la llegada del Mesías (en ciertas interpretaciones místicas habría permanecido la Shjina, una radicion de Dios que representa lado femenino). La ausencia divina implicó que no sería más posible que existieran profetas que pudiesen vocalizar la palabra de Dios, al cual sólo se puede tener acceso a través del estudio de la Torah. Pero ella también llevó a considerar la historia como insignificante, pues Dios deja de estar presente en ella.

Así, el mundo del Talmud pasó a ignorar los eventos históricos, y los escritos rabínicos prácticamente nunca relatan las situaciones vividas por los judíos en la diáspora, aún las más dramáticas. Los rabinos se relacionan a ellas solamente cuando movilizan problemas relevantes para la práctica religiosa (por ejemplo, en tiempos de persecución, el derecho a autoinmolarse en lugar de aceptar la conversión forzada). En el universo creado por el Talmud, el mundo terreno, la historia local, prácticamente desaparece. La "realidad" es la Torah, su estudio y el cumplimiento de los mandamientos. Se trata así de un mundo donde lo real es el texto y sus significados, donde la Torah, adquiere un sentido transcendental, la única realidad vital, la referencia a la cual los judíos se debían atener hasta la llegada del Mesías. La vivencia del tiempo construida por el Talmud es dada por las oraciones, el descanso sabático, las fiestas anuales y la eternidad de la Torah. Un tiempo cíclico que sólo será roto con la llegada del Mesías.

La política igualmente pierde su lugar en el mundo talmúdico. La experiencia de los conflictos de los fariseos con los reyes Macabeos y de los desastres producidos por los dos grandes levantamientos contra Roma (en el segundo Templo y contra el Emperador Adriano) llevó a los rabinos a ignorar la política como mecanismo para cambiar el destino del pueblo judío. Los rabinos declararon que Dina d'maljuta dina, o sea, la ley del reino es la ley. Se negaron a incluir el libro de los Macabeos dentro del canon bíblico, y, aunque hayan aceptado festejar la liberación de Jerusalén y la purificación del Templo obtenida gracias a la rebelión, la fiesta de Januká fue transformada en la celebración no de la victoria militar, sino del milagro divino que permitió que un poco de aceite se mantuviese encendido por ocho días. En el texto de la Hagada leída en la fiesta de Pesaj, que conmemora la salida de Egipto, Moisés, el gran político y estadista que lideró el pueblo, sólo es nombrado una única vez.

El Talmud, creó un universo auto-referido, que retira la temporalidad del relato bíblico, en una interpretación muy distante del original, en el cual el pueblo y su cultura se construyen a través de su historia. Pero, no sólo la temporalidad es retirada del texto bíblico, también la relevancia de la experiencia histórica. En el cuadro del pensamiento talmúdico las innovaciones son presentadas como fundadas en la tradición y no como adaptaciones a las mutaciones en la realidad social.

Aunque algunos vean el judaísmo rabínico, a partir de una mirada contemporánea, como algo osificado y dogmático, se trata de una visión anacrónica, una reacción frente a la forma en que el judaísmo talmúdico es practicado en la actualidad, olvidando su originalidad, creatividad y vitalidad durante un extenso período histórico. Más aún, el judaísmo rabínico produjo un universo psíquico, práctico y cognitivo que continúa influyendo el judaísmo hasta los días de hoy.

La cultura talmúdica tuvo importantes consecuencias no intencionales sobre las chances de vida e integración social de los judíos en la diáspora, en particular en los tiempos modernos. Ella valorizó el estudio 
de la Torah, que, junto con los largos libros de oraciones que exigían capacidad de lectura, llevó a que las comunidades judías alcanzasen un altísimo índice de alfabetización masculina antes de los tiempos modernos. Sobresalir en el estudio era un camino de movilidad social en una comunidad donde el erudito inspiraba un gran respeto. La complejidad del estudio rabínico de la Biblia y la valoración de la capacidad de los estudiantes de encontrar problemas y nuevas interpretaciones, más allá del sentido explícito en el texto, ciertamente influyeron profundamente en la psique colectiva. Ellas generaron una combinación de individualismo intelectual y creencias colectivas compartidas, valorizaron simultáneamente el sentido de comunidad y la competitividad para destacarse en los estudios. En suma, una cultura simultáneamente comunitaria e individualista, solidaria y competitiva, que reverbera hasta los días de hoy.

El estilo de vida definido por el judaísmo talmúdico unificaba todas las clases sociales, que, junto con las instituciones de caridad y el sentimiento compartido de minoría oprimida, disminuía la distancia social y producía una gran cohesión social. A pesar de las desigualdades de riqueza, el judaísmo talmúdico no poseía castas, al contrario de la sociedad cristiana y musulmana en la Edad Media. Así, diferencias entre ricos y pobres, cultos e incultos, podían ser enormes, pero nunca se cristalizaron en grupos sociales separados. Los sacerdotes (cohanim y leviim) perdieron sus prerrogativas, a no ser el privilegio de ser llamados en primer lugar al púlpito, durante los intervalos de lectura de la Torah, y de ser obligados a cumplir con mayor rigidez las reglas de pureza (por ejemplo, no siéndoles permitido casarse con mujeres divorciadas). Al final, los rabinos esperaban que, con la llegada del Mesías, el Templo sería reconstruido y los sacerdotes volverían a ocupar su lugar.

El disciplinamiento del cuerpo y de la mente exigido por el cumplimiento de los mandamientos creó un individuo con enorme autocontrol físico y emocional, que muchos autores asocian solamente a los tiempos modernos. Todos estos elementos se mostraron altamente favorables y facilitaron la ascensión social de los judíos cuando les fue permitido participar en todas las profesiones, en sociedades donde las poblaciones eran mayormente analfabetas en un mundo donde la cultura literaria se restringía a las elites.
El judaísmo talmúdico fue un manual de sobrevivencia de un pueblo políticamente vencido, que se veía condenado a vivir como minoría en el exilio hasta la llegada del Mesías. Esto no significa que los judíos no hayan "hecho política" en la diáspora, inclusive en la Edad Media. Sólo que esta política tenía un sentido pragmático, de alianzas con los poderes locales que asegurasen la protección y prerrogativas de las comunidades judías. Pero, se trataba de una política mundana, sin ningún significado transcendental. 


\section{El MUNDO TALMÚdico EN LA EDAd MEDIA}

$\mathrm{E}^{1}$ 1 Talmud fue un enorme esfuerzo de innovación, pero, al mismo tiempo, creó mecanismos que cerraron la posibilidad de cuestionamientos profundos. La tradición talmúdica considera que las interpretaciones de las generaciones más antiguas tienen precedencia sobre las generaciones posteriores, creando así un sistema de legitimación en el cual existe un espacio muy limitado para innovaciones, que deberían ser sustentadas con referencia al texto talmúdico. Si el Talmud transformó el pshat (simple) en drash (interpretación), el universo rabínico posterior transformó el nuevo drash si no en un pshat, por lo menos en una senda muy estrecha hasta la llegada de la modernidad.

Hasta los tiempos modernos, a pesar de la dispersión e inexistencia de una autoridad central, el judaísmo talmúdico fue extremamente exitoso en mantener su unidad. Esto no significa que no hayan surgido en su interior divisiones y tensiones. Pero los cambios en el judaísmo rabínico se dieron, fundamentalmente, en los márgenes.

En primer lugar, el problema de definir cuál interpretación entre las varias escuelas rabínicas debía ser seguida. En el Talmud, se presentan dos grandes escuelas, asociadas a los liderazgos de Hillel y de Shamai. Mientras la escuela de Shamai enfatiza el máximo rigor, la visión de Hillel es más tolerante. La Halaja (esto es, la interpretación que debe ser seguida según la tradición) acompaña las interpretaciones de la escuela de Hillel.

En segundo lugar, surgían nuevos problemas y situaciones a ser resueltas, para los cuales los rabinos, o sínodos de rabinos, elaboraban nueva legislación (por ejemplo, la prohibición de la poligamia, por influencia del Medioevo cristiano). En ciertos casos, en particular con la expansión de las actividades económicas y el surgimiento de nuevos instrumentos de crédito en el siglo XVI, fue necesario modificar las reglas relativas a préstamos y los tipos de comercio permitidos con los no judíos, llevando a cambios de la legislación con tenue sustentación en el texto talmúdico.

La acumulación de siglos de pequeñas modificaciones generó la necesidad constante de organizar y sistematizar el repertorio de leyes y ritos. En el Siglo XVI, el rabino Yosef Karo escribe el libro Shuljan Aruj, hasta hoy considerado la principal codificación de referencia en cuestiones de Halaja Pero los esfuerzos de compilación de las leyes continúan hasta los días de hoy.

Además de interpretaciones de fondo, se desarrollaron diferentes minhagim (costumbres) en relación a las formas de festejar ritos o la organización de los libros de oraciones. La principal diferencia se dio entre las tradiciones sefaraditas (la población vivía mayoritariamente en el mundo islámico - y que incluye buena parte de los descendientes de la población judía que vivió en España y Portugal hasta la expulsión de 1492) y la ashkenazi, que vivía en la Europa cristiana.

Los sefaraditas y ashkenazim crearon tradiciones diferentes de estudio del Talmud. En el mundo cristiano, envuelto en una Edad Media donde los judíos eran constantemente perseguidos y estaban rodeados de una cultura poblada de creencias mágicas y tendencias ascéticas y místicas, el judaísmo talmúdico se encerró sobre sí mismo, sin por eso dejar de asimilar creencias y conductas del medio católico. Entre los grandes rabinos de este período sobresale la figura de Rashi (Rabi Shlomo Itzjaki), nacido en la ciudad francesa de Troyes en el siglo XI, que escribió comentarios detallados al texto bíblico y al Talmud, que posteriormente pasaron a ser de referencia obligatoria, incluidos en buena parte de las reproducciones de estos textos.

Fue en el mundo sefaradita, en particular en los momentos de mayor apertura y tolerancia en España bajo dominio musulmán, que se mantuvo encendido un diálogo explícito con la cultura externa, y en el cual surgieron las figuras más innovadoras del judaísmo talmúdico. Todos estos autores escribieron generalmente en árabe o árabe-hebraico (árabe en letras hebraicas) y fueron influidos por la filosofía griega y las nuevas técnicas de lectura e interpretación de textos. Así, en el siglo XI D. C., Salomón Ibn Gavirol, de Zaragoza, profundizó en el neoplatonismo y Moisés Ibn Ezra, de Granada, hizo los primeros estudios lingüísticos de la Biblia y escribió poesías que renovaron el hebraico, algunas de las cuales son recitadas en Rosh Hashana y Iom Kipur.

La figura emblemática de la época es Maimónides, el RaMBaM (Rab Moishe Ben Maimon, en árabe Imran Mussa bin Maimun ibn Abdallah alQurtubi al-Israili), que vivió en el siglo XII. Nacido en Córdoba, su familia huyó al sur de España y después para Marruecos, cuando los Almohades conquistaron parte de España y dieron fin a la tolerancia religiosa. Además de filósofo, era considerado uno de los mayores médicos de su época y, en las 
últimas décadas de su vida, se estableció en Egipto. Allá fue médico personal del gran Vizir y del Sultán Saladino.

Los libros de Maimónides incluyen la Mishna Torah, un compendio de las leyes rabínicas que continúa siendo una referencia hasta los días de hoy. En su libro La Guía de los Perplejos, Maimónides busca sintetizar el judaísmo con la filosofía griega, pero defendiendo la versión bíblica cuando ella contradice la versión aristotélica. Argumentó a favor del estudio de la naturaleza y se opuso a la visión antropomórfica de Dios, que llevaría a la idolatría y - siguiendo filósofos neoplatónicos - argumenta que Él sólo puede ser definido por sus atributos negativos (lo que Dios no es). Rambam procuró disminuir la importancia del misticismo y presenta una versión de la llegada del Mesías como un evento fundamentalmente político, de reconstrucción del Reino de David y retorno de los judíos a la tierra de Israel.

La obra de Maimónides fue ampliamente reconocida por los filósofos de la época, inclusive por Tomás de Aquino, pero, en el mundo judío, pasaron siglos hasta que fuese valorada. En la Europa medieval varios rabinos inclusive censuraron la lectura de la Guía de los Perplejos. Con la llegada de la modernidad, el Rambam pasó a ser reconocido como una figura pionera, seguidor del Talmud, al mismo tiempo en que dialoga con la filosofía y reconoce la importancia de estudiar el mundo natural.

Además de la influencia islámica, el judaísmo en el mundo musulmán tuvo que enfrentar el Caraísmo, un movimiento iniciado en el siglo VIII D. C., en la Mesopotamia, y que sostenía que el único texto sagrado era la Biblia. El Talmud serían mandamientos producidos por personas cultas y tradiciones, pero no tendrían la fuerza de los mandamientos bíblicos. El Caraísmo representó un movimiento similar al protestantismo, de retorno al texto original que debía ser objeto de la interpretación directa de cada individuo.

La necesidad de responder a los Caraítas llevó a una serie de nuevos argumentos para legitimar el Talmud, que se alejaban de la respuesta tradicional. Así, Saadia Gaon (siglo IX/X D. C.), nacido en Fayum, Egipto, enfatizó la necesidad de llenar las lagunas en el texto bíblico y que el Talmud presentaría las respuestas aceptadas por la tradición. Posición similar fue elaborada por Iehuda Halevi y Abraham Ibn Ezra (siglo XI/XII), ambos nacidos en Tudela, España. Aceptando por un lado que los sabios talmúdicos expresaron una tradición auténtica y correcta de la Biblia, ellos disminuyen la importancia de exégesis rabínica. Serían asmajtas, apoyos para justificar tradiciones y no tendrían el valor teológico que el judaísmo talmúdico pretendía darles.

Maimónides también no se sentía cómodo con la versión de que el Talmud tenía el mismo status que la Biblia, en particular cuando él presenta interpretaciones conflictivas. Para Maimónides, Dios no podría haber producido varias interpretaciones y concluye que las leyes que son producto de exégesis son mi-de-rabbanam, o sea, producto de la tradición elaborada por los rabinos. Esto no significa para él que no deban ser obedecidas, pero no deben ser colocadas en el mismo nivel que las leyes explicitadas en la Biblia.

Así, en un contexto en que el judaísmo era influido por la cultura externa y debatía con otras tendencias del judaísmo, se vio obligado a formular nuevas justificativas para legitimar el texto talmúdico. Pero, era un mundo cultural donde la referencia a la tradición era un valor absoluto y tenía fuerza de ley.

El cierre del mundo musulmán y del cristianismo, en particular a partir de las cruzadas y de la Reconquista de la península Ibérica, se reflejó en el judaísmo, marginalizando los debates sobre el fundamento del Talmud por varios siglos, hasta que vuelven a la superficie, en la modernidad, en un contexto en que la tradición dejó de ser suficiente para justificar un argumento.

Junto con el desarrollo del universo talmúdico, el judaísmo siempre tuvo una corriente mística, la Kabalah, cuyo principal texto de inspiración son las profecías apocalípticas de Ezekiel, donde Dios aparece en un trono montado en una carroza movida por cuatro animales. La Kabalah busca profundizar el conocimiento de las cualidades de Dios, de la creación del mundo y de la llegada del Mesías. Siendo que Dios no puede ser conocido en su esencia, ya que es infinito, la Kabalah es una elaboración de sus emanaciones, que expresan atributos divinos (sefirot). Como en la tradición hebraica los números eran letras del alfabeto, los kabalistas, siguiendo una tradición que ya estaba presente en el Talmud, hicieron uso de la gematría, la interpretación del texto bíblico por el valor numérico de las letras.

En la tradición talmúdica existen cuatro niveles de interpretación de la Biblia, el Pshat (el texto simple), el Remez (lo que el texto da a entender), el Drash (la interpretación), y el Sod (secreto, la dimensión 
mística). Las cuatro letras forman la palabra PaRDes (pomar). En el Talmud, existe una gran reticencia a las incursiones en el Sod, la dimensión mística, pues ella podría llevar a la locura o a la apostasía. Los rabinos aconsejaban circunscribir el estudio de la Kabalah a personas más viejas, con sólida formación talmúdica.

En el siglo XVI, la Kabalah se renueva con las nuevas contribuciones de la escuela de Sfad, ciudad localizada en Galilea, en la época bajo el imperio otomano, que inspirará los grandes movimientos sociales surgidos en los siglos XVII y XVIII, el movimiento mesiánico de Shavetai Tzvi y el Hassidismo. Las principales figuras de este movimiento renovador de la Kabalah fueron Isaac Luria y Jaim Vital, que recopiló las enseñanzas de Luria. En el centro de la versión Luriática se encuentra la explicación de la creación del mundo por la retracción (tzimtzum) de Dios. La retracción de Dios habría sido un proceso por el cual Dios dejó de ocupar todo el espacio y, en el vacío creado, todavía poblado con chispas divinas, habría surgido el universo. El sentido exacto de la retracción de Dios fue y continúa siendo objeto de debates en el interior de la ortodoxia, particularmente por permitir una interpretación panteísta del mundo (el universo no sería exterior a Dios, sino parte de él). Para muchos autores, esta versión estaría asociada al trauma de la expulsión de España y a la búsqueda de una explicación transcendental para la diáspora. De la misma forma que el pueblo judío estaba exilado, Dios se exiló para crear el mundo.

El nuevo misticismo vino al encuentro de los sentimientos de frustración y de las esperanzas mesiánicas desencadenadas por la expulsión de España y después por las masacres de decenas de millares de judíos en Ucrania, por el líder cosaco Jmelnitzki.

En el siglo XVII, en Esmirna, en Turquía, un joven rabino influido por las enseñanzas kabalísticas, Shabetai Tzvi, se autoproclama el Mesías. Recorriendo varias ciudades del imperio Otomano recibió el apoyo de personas poderosas y de rabinos. Shabetai comenzó a realizar actos de transgresión de las leyes talmúdicas, con justificación basada en referencias talmúdicas, de que en el final de los tiempos varios mandamientos serían abolidos. Finalmente, junto con algunos de sus seguidores, se convierte al islamismo.

El impacto de Shabetai no se restringió al imperio otomano. En Europa, generó una enorme ola de apoyo. Las sinagogas incluyeron rezos en su alabanza, y muchos judíos vendieron sus pertenencias, preparándose para ir para Israel. Con la conversión de Shabetai al islamismo, el Shabetaísmo perdió su fuerza, aunque hasta recientemente se mantuvieron pequeños grupos de seguidores. Después de su muerte surgieron varias figuras proclamándose reencarnaciones de Shabetai, siendo la más influente Jacob Frank, en Ucrania en el siglo XVIII. Finalmente, él se convirtió al catolicismo. Para los seguidores de estas sectas, la conversión y la transgresión de los mandamientos era vista como forma de acelerar la llegada de los tiempos mesiánicos.

En el siglo XVII, también en Ucrania, surge el jasidismo, un movimiento que afectará profundamente el judaísmo. Su fundador fue Israel ben Eliezer, más conocido por el nombre del Baal Shem Tov (literalmente Poseedor de Buen Nombre, así llamadas las capaces de realizar curar e inclusive milagros). Sin cuestionar la necesidad de cumplir los mandamientos rabínicos, Baal Shem Tov, propuso una visión renovada del judaísmo. Influido por la Kabalah de Luria argumentó que Dios continúa presente en el mundo y en el interior de cada persona. Siendo así, debemos ser comprensivos con los pecadores, pues toda persona puede recuperar sus dimensiones divinas. Como la presencia divina continúa estando en el mundo, inclusive cuando los judíos se encuentran en el exilio, el universo continuaría evolucionando hasta la llegada de los tiempos mesiánicos.

El jasidismo se opone a la visión ascética de la Kabalah de Sefad, enfatizando la expectativa mesiánica, la alegría de vivir y de los placeres que la vida puede ofrecer. Sin abandonar los mandamientos, dio importancia particular a las oraciones, a la música y al canto para alcanzar el éxtasis y el contacto con Dios. De esta forma, colocó la intención y la emoción, más que el estudio, como camino para comunicarse con Dios. Baal Shem Tov y sus continuadores utilizaban cuentos y parábolas para transmitir sus mensajes, muchas veces tomados del folclore popular de la región, en lugar de la exégesis erudita. Muchas de esas anécdotas, atribuidas a él y sus continuadores, son de una enorme belleza y fuerza moral.

Los milagros que le eran atribuidos a Baal Shem Tov - y posteriormente a los herederos del movimiento - y la valoración del hombre simple y poco cultivado vinieron al encuentro de una población judía en la Europa Oriental que había sido estremecida por las persecuciones y las difíciles condiciones de vida. Para algunos autores, parte del éxito del 
jasidismo es atribuible al apoyo dado al movimiento por miembros ricos de las comunidades judías, como forma de limitar el poder de los rabinos.

Aunque apoyado por algunos talmudistas, el movimiento jasídico encontró fuertes resistencias, en particular en los grandes centros de estudio en Lituania. Para el principal rabino de la época, el Gaon (sabio) de Vilna, las interpretaciones de Baal Shem Tov podían llevar a la negación de la separación entre Dios y el mundo y a la desvalorización del estudio del Talmud. El jasidismo dividió el judaísmo religioso, y, hasta la Segunda Guerra Mundial, el judaísmo ortodoxo de Europa Oriental estaba polarizado entre los que apoyaban el jasidismo y sus opositores (mitnagdim). El conflicto entre ambos llegó al uso de denuncias mutuas a las autoridades locales.

Después de la muerte de Baal Shem Tov, el movimiento jasidico se dividió entre diferentes escuelas y líderes (llamados rebes), que transmitían sus posiciones para sus hijos o familiares, muchos de los cuales crearon verdaderas cortes que circulaban entre los poblados judíos, recibiendo presentes y donaciones de la población pobre que esperaba ser agraciada por milagros.

Una de las corrientes jasídicas, el JaBaD (de Jojma - sabiduría, Bina - comprensión, y Daat - conocimiento) o Luvabitch (por el nombre de la ciudad rusa donde surgió) procuró sintetizar la tradición jasídica, que valora la emoción, con el estudio. Transferido para Estados Unidos antes de la Segunda Guerra Mundial, el Jabad se transformó en el principal movimiento ultraortodoxo contemporáneo.

El movimiento jasídico representa una importante inflexión en el interior del judaísmo talmúdico. En primer lugar, porque creó la figura del Rebe, con poderes especiales y una capacidad particular, encima del resto, de comunicarse con Dios y, para muchos, de realizar milagros. En segundo lugar, porque colocó en el centro del judaísmo el estudio del misticismo y la esperanza mesiánica, que habían sido frenadas en la tradición rabínica. En tercer lugar, porque la creencia en la presencia divina en cada judío (que en la versión de los Luvabitch significa que cada judío posee una alma conteniendo una chispa divina) generó una tolerancia en relación a aquellos que no seguían los mandamientos, que no existía en el judaísmo talmúdico tradicional, promoviendo una disposición proselitista.
El éxito del Shabetaísmo y del Jasidismo expresaba un "cansancio" de las masas judías con la tradición talmúdica. La llegada de la modernidad creó una oportunidad para reorientar en forma dramática el judaísmo. 


\section{JUDÍOS, CRISTIANOS Y MUSULMANES}

ntes de entrar en los tiempos modernos, debemos hacer una pausa para referirnos a la percepción corriente que tenemos sobre las relaciones entre el judaísmo y el universo religioso en el cual él se desarrolló durante casi dos mil años. Un universo bajo la hegemonía del cristianismo, posición que posteriormente dividirá con el Islam. Rever nuestra percepción de esta relación es fundamental para comprender la trayectoria del judaísmo en la cultura occidental y, de esta forma, repensar el judaísmo.

La representación estándar que los judíos cristalizaron en relación al cristianismo (y con menor intensidad, pero no fundamentalmente diferente, en relación al islamismo) es una relación de víctima con su verdugo. Esta visión se sustenta en una historia de demonización, persecución, expulsión, conversión forzada, inquisición, masacres, confinamiento en guetos, quema de libros, prohibición de realizar proselitismo y de actuar en ciertas profesiones. Historia de sufrimiento promovida por un discurso elaborado por la Iglesia y por el Islam que destilaba odio contra los judíos.

Esta actitud se alimentaba de la propia teología cristiana, que reconoce la Biblia como un texto sagrado y Jesús como un judío que predicaba a su pueblo. El rechazo de los judíos a reconocer Jesús como el Mesías y posteriormente a Mahoma como Profeta, creaba un problema de legitimidad para el cristianismo, y posteriormente para el islamismo. Tanto Paulo de Tarso como Mahoma expresaron explícitamente la frustración de no conseguir convencer a los judíos a seguir la nueva versión del relato bíblico.

La renuencia de los judíos a reconocer Jesús como Mesías llevó al cristianismo a producir varias explicaciones teológicas. La principal era de que Dios transfirió su alianza con los judíos para su "nuevo pueblo". La diáspora del pueblo judío y la destrucción del Templo habrían sido un castigo divino. Pero la tradición más dañina fue la transformación de Judas en símbolo del judío y de la crucifixión de Jesús en responsabilidad colectiva y eterna del pueblo judío. De esta forma, buscó transformar al pueblo elegido de la Biblia en el pueblo maldecido por no haber aceptado Jesús como Cristo. Haciéndolo, transgredió el precepto bíblico de no culpar los hijos por los pecados de los padres (suponiendo que tal pecado haya existido), construyendo una cultura de odio y antisemitismo que impregnó profundamente el cristianismo hasta el siglo XX.

Pero, si esta teología permitió justificar los malos tratos y persecuciones, no eliminó la ambigüedad original del cristianismo en relación al judaísmo (al final los Evangelios presentan un Jesús judío, cuyo papel mesiánico es justificado por una genealogía que lo relaciona con el Rey David, y la propia iglesia mantuvo el festejo del año nuevo en el día de la circuncisión de Jesús y la Última Cena durante el Pesaj). En relación a otras religiones, la Iglesia y el Islam tuvieron una política única, la de la eliminación por la conversión forzada y fueron extremamente exitosos en esta tarea. En relación a los judíos, el cristianismo y el islamismo fueron más ambiguos, porque el judaísmo tenía un lugar en sus teologías que ninguna otra religión poseía. La sobrevivencia del judaísmo se explica en primer lugar por su voluntad de persistencia y resistencia en contextos extremamente hostiles, pero igualmente no podemos dejar de considerar que en general estos ambientes permitieron la sobrevivencia de los judíos

La aspiración del cristianismo y el Islam fue, y, y para mucho continúa siendo, la desaparición del judaísmo por el reconocimiento de la divinidad de Cristo o del papel profético de Mahoma. En ciertas teologías evangélicas, en boga en Estados Unidos, la conversión de los judíos inclusive preanunciará la llegada de los tiempos finales o es su precondición. Pero la conversión forzada sólo fue usada en circunstancias relativamente aisladas y no era la política oficial del Vaticano. La posición del Islam, en lo fundamental, fue similar.

No se trata, obviamente, de excusar a la Iglesia o el Islam por la violencia cometida y el odio que diseminaron, aún presente en nuestros días, sino de reconocer que esta violencia fue limitada por las relaciones complejas que ambos mantenían con el judaísmo. Relaciones que no se referían solamente al pasado bíblico común y al origen judío de Jesús y del cristianismo y de la reproducción, en versión propia, del relato bíblico por El Corán, sino de una herencia común que permitía un intercambio cultural que se mantuvo por largo tiempo. En la Edad Media, bulas papales eran bajadas para prohibir el contacto con los rabinos, cuyo conocimiento de la Biblia hebraica era reconocido por el clero católico y por los sabios musulmanes, cristianos y judíos que mantenían encuentros teológicos en la España mora. 
El judaísmo fue, y en cierta medida continúa siendo, para las religiones monoteístas universalistas (el cristianismo y el islamismo) un otro que no es totalmente diferente, pues tiene un lugar en el discurso dominante. Como tal, no puede ser totalmente negado como lo diferente con lo cual no nos identificamos, pero también irrita porque no acepta ser absorbido. Así, la relación con los judíos siempre tuvo la marca de la ambigüedad, pues él comparte elementos de las culturas hegemónicas, pero al mismo tiempo no acepta la versión de la mayoría.

Pero, existe también ambigüedad del judaísmo con las dos religiones monoteístas: la dificultad de reconocer la contribución del cristianismo (y del islamismo) al judaísmo. Me explico: los judíos nos enorgullecemos de nuestra contribución a la civilización, en particular del monoteísmo, los diez mandamientos, la idea de la redención mesiánica y el día de descanso semanal. Pero todas estas innovaciones habrían quedado restrictas a los judíos, si no fuese por el cristianismo y el islamismo. El judaísmo era fundamentalmente centrado en sí mismo. Si las innovaciones del judaísmo fueron diseminadas por el mundo - y no cabe aquí una discusión de si esto fue bueno o realizado de forma respetuosa a las personas y pueblos convertidos por el islamismo y el cristianismo - fue gracias al hecho de que estas ideas fueron asumidas por religiones con vocación universalista.

Por lo tanto, la contribución judaica a la cultura universal tuvo como vehículo el cristianismo y el islamismo. Sin ellos, no habría existido tal contribución a la civilización universal, pues no era ésta la intención de la cultura bíblica o talmúdica. Esto no retira el mérito de que los "derechos de autor" originales de algunas de las ideas centrales diseminadas por el islamismo y por el cristianismo (en versiones propias) hayan sido de origen judaica, pero obliga a un acto de reconocimiento del papel desempeñado por las otras grandes religiones monoteístas. Este reconocimiento es importante, pues permite una visión más compleja, rica y menos narcisista del papel que cada religión desempeñó en la formación de la civilización contemporánea. Pues, si los judíos se enorgullecen del lugar original en la creación del monoteísmo y se resienten de la tendencia de cristianos y musulmanes a ocultar o disminuir este papel, ellos no dejan de tener una visión igualmente parcial de su lugar en la historia.

Las religiones institucionalizadas, en sus versiones integristas o fundamentalistas, comparten todavía fuertes componentes autoritarios, no respetan a las otras religiones y no están dispuestos a aceptar sociedades fundadas en el principio de la libertad individual, en la libre expresión de ideas y de organización y en el derecho de cada persona de conducirse de acuerdo con su conciencia. Todas las versiones religiosas ortodoxas, judía, cristiana e islámica, caso asumiesen el poder, destruirían la democracia.

En la medida en que reconocemos que las grandes religiones monoteístas están profundamente relacionadas entre sí, podemos avanzar en una visión menos dogmática y fundamentalista de cada una. Igualmente debemos reconocer que la Iglesia Católica, cuya integración en el mundo moderno fue un proceso complejo y aún inacabado, realizó avances fundamentales en el sentido de eliminar de su teología los componentes antisemitas, a partir del Concilio Vaticano Segundo (1962-1965) bajo el liderazgo admirable de Juan XXIII. Esta transformación - que incluye el reconocimiento de la permanencia de la alianza de Dios con el pueblo judío y reniega la idea de responsabilidad colectiva por la muerte de Jesús-, sin duda influida por el Holocausto y por la responsabilidad indirecta de la Iglesia por haber alimentado sentimientos antisemitas en el mundo cristiano, abrió las posibilidades de respeto mutuo y diálogo inter-religioso.

Este diálogo es fundamental para un conocimiento mutuo y para encontrar un espacio de valores comunes, sin que esto signifique que cada una abdique de sus especificidades. Un diálogo no solamente a ser realizado por líderes religiosos, sino también por intelectuales seculares judíos, cristianos e islámicos, pues, no sólo en el judaísmo como también en el cristianismo y en menor medida en el islamismo, cada uno con sus especificidades, la tradición religiosa se transformó hoy en una tradición cultural. Buena parte de los judíos, cristianos y, en menor medida, musulmanes, se relaciona hoy con las religiones como tradiciones culturales sin atenerse a las instituciones y reglas que ellas procuran imponer. 


\section{LA MODERNIDAD:}

\section{EL RETORNO DE LA FILOSOFÍA, DE LA HISTORIA Y DE LA POLÍTICA}

1 judaísmo talmúdico fue exitoso en circunstancias históricas precisas, en que las sociedades eran organizadas en torno de sistemas políticos y culturales dominados por religiones monoteístas que lo aislaron. Así, el cierre del judaísmo sobre sí mismo estuvo asociado al cierre de las sociedades en relación al judaísmo. El mundo talmúdico fue fruto de la derrota política y militar y sirvió como estrategia de sobrevivencia de un pueblo exilado, viviendo como minoría en el seno de sociedades con religiones oficiales sustentadas por el poder político. La modernidad trajo nuevas exigencias y posibilidades e implosionó el universo rabínico. Los tres elementos reprimidos por el judaísmo talmúdico, la historia, la política y la filosofía, pasaron a ocupar central el judaísmo moderno.

El judaísmo moderno corresponde al período histórico que se extiende desde el Iluminismo y la Revolución Francesa hasta el Holocausto y la creación del Estado de Israel. Un período que duró aproximadamente dos siglos y que se nutrió de los valores universalistas del Iluminismo y de los derechos humanas y la ciudadanía nacional de la Revolución Francesa. Como fenómeno sociocultural, el judaísmo moderno fue, fundamentalmente, una creación de los judíos radicados en Europa, particularmente en las grandes ciudades, como Berlín y Viena y posteriormente Varsovia y Kiev, y, en el siglo XX, Nueva York. Para buena parte de las comunidades judías que habitaban en el mundo musulmán, un contacto fuerte con sociedades modernizadas solo se dio en la década del 50 del siglo pasado con la inmigración masiva a Israel y Europa.

Los tiempos modernos crearon condiciones inéditas de convivencia del judaísmo con un estado laico, transformando radicalmente las posibilidades de participación social, modificando la visión de los judíos de lo que sea el judaísmo. Lo que no significa que las relaciones entre judaísmo y modernidad, de ambos lados, no hayan sido extremamente conturbadas. Inicialmente, con el fin de la Edad Media y la ascensión del absolutismo en Europa Occidental, la centralización del poder político y la tendencia a homogeneizar culturalmente las sociedades llevaron a la expulsión de los judíos de muchos países de Europa Occidental, resultando en el desplazamiento de gran parte de ellos para Europa Central y Oriental.

La expulsión en 1492 de España y Portugal, que, en la práctica, llevó a la conversión forzosa de la mayoría de los judíos ibéricos, ya que sólo una minoría emigró, seguida de la Inquisición, significó un trauma enorme para el judaísmo e impactó en la memoria colectiva durante siglos. En España y Portugal el Estatuto de Pureza de Sangre, estableció la primera forma de racismo moderno, con leyes que excluían los cristianos-nuevos (recién convertidos) y sus descendientes de órdenes religiosas o de la carrera militar.

Con el avance del mercantilismo, los judíos pudieron retornar, en pequeño número, a Francia e Inglaterra. En Europa Occidental, solamente Italia, dividida en pequeños reinos y Holanda, una precoz potencia mercantil con un sistema político más abierto, recibieron parte de los judíos expulsados de la Península Ibérica. Serán los judíos holandeses que construyeron las primeras sinagogas en el Nuevo Mundo, en Recife, acompañando la invasión de Brasil por la Compañía Holandesa de las Indias Occidentales, en el siglo XVII, y, cuando fueron expulsados de allá, en Nueva Ámsterdam (Nueva York)

El Iluminismo y la Revolución Francesa encuentran el pueblo judío extremamente debilitado. Se calcula que su número era 1.000 .000 en 1700 , uno de los menores de su historia. La mayoría de estos judíos vivía en Europa Oriental, la mayoría en condiciones de pobreza, sin derecho a transitar de un lugar para otro y sufriendo constantes masacres.

Aunque la modernidad haya generado enormes conflictos en el interior de la comunidad judaica, entre defensores de la tradición y del cambio, entre padres e hijos, la rapidez y la disposición con que buena parte de los judíos se dispuso a aceptar los nuevos valores se explica por los siglos de opresión y humillación que precedieron al Iluminismo. La modernidad irrumpe en la vida judaica como una promesa de liberación, y muchos judíos interpretaron la Revolución Francesa como una anticipación de la llegada del Mesías.

El universo medieval era un mundo sometido a las creencias instituciones religiosas. El rey reinaba por la gracia de Dios y el conocimiento era producido, filtrado y censurado por el clero (o, en el caso del judaísmo, por los rabinos). El proceso que hoy denominamos secularización separó la 
política de la religión y transfirió a la voluntad popular la fuente de legitimidad del poder. La producción de conocimiento, a partir de la revolución científica, pasó a fundarse en la experimentación y en hipótesis refutables, en lugar de dogmas eternos sobre la naturaleza y la sociedad. La filosofía desarrolló una imagen nueva del ser humano, centrada en el individuo libre, orientado por la razón. En lugar de personas resignadas frente a un estado de cosas que sería producto de la voluntad divina, la creencia en la capacidad del ser humano de transformar el mundo a su voluntad llevó a la irrupción de ideologías políticas con proyectos de reforma social.

Así, las sociedades modernas, en un largo proceso histórico, nunca completo y hasta hoy cuestionado por grupos religiosos ortodoxos e ideologías políticas autoritarias, pasaron a valorar la libertad y el derecho de cada individuo a actuar de acuerdo con su conciencia. Este proceso culminó con la creación de las instituciones democráticas, que suponen que cada individuo, independientemente de sus creencias personales, usufructúa ante la ley y en el espacio público, de los mismos derechos y deberes.

Los valores de la modernidad no exigían que el judío se convirtiese a otra religión para absorber las nuevas ideas y valores, - aunque, como veremos, en Alemania y en el Imperio Austro-Húngaro éste no haya sido exactamente el caso. Para los judíos que entraron en contacto con los valores de la modernidad, eso significó la posibilidad de salir del gueto, de dejar de ser excluidos de profesiones, de vivir estigmatizados y, sobretodo, de participar activamente de la construcción de un mundo en que todos los seres humanos son libres e iguales. Todo esto, sin dejar de ser judíos.

Esta travesía fue, y continúa siendo penosa, no sólo porque exigió transformaciones profundas en el judaísmo, como porque el avance de los valores iluministas fue tortuoso, presentando retrocesos periódicos a veces dramáticos, como fue el nazismo. Estos retrocesos producen constantemente entre los judíos una dicotomía interna. entre la voluntad de creer en las promesas de la modernidad y el miedo de que la pesadilla del antisemitismo pueda siempre resucitar.

A pesar de la oposición de los rabinos a los valores modernos, ellos penetraron en la vida cotidiana y, sobretodo, en las mentes y corazones de la mayoría de judíos, diluyendo el mundo comunitario auto-centrado, con fuerte control social, donde el rabino legislaba en asuntos civiles y comerciales. En cada país, de acuerdo con las condiciones locales, los judíos iban absorbiendo los valores de la modernidad y distanciándose del mundo talmúdico. Esta transformación fue elaborada a partir del siglo XVIII por nuevos liderazgos intelectuales seculares y religiosos, culminando en el siglo XX con el desplazamiento de los rabinos ortodoxos como principal elite cultural del judaísmo.

En un largo proceso histórico, del cual aún somos parte, intelectuales seculares y religiosos elaboraron nuevas visiones e ideologías que insertaban el judaísmo en los valores e ideales de la modernidad. La filosofía iluminista, la argumentación científica y la visión de la historia como producto de la acción humana y no de un diseño divino, penetraron en el judaísmo, llevándolo a su fragmentación en diversas corrientes.

El autor paradigmático de la transición a esta nueva fase fue Baruj Spinoza, que vivió en el siglo XVII en Ámsterdam. Como todo esfuerzo pionero, fue solitario y reactivo frente a una comunidad todavía sólidamente controlada por la ortodoxia. En él predomina la salida en lugar de un esfuerzo de elaborar una alternativa al judaísmo talmúdico. Como ocurrió con muchos judíos después de Spinoza, el cierre institucional y cognitivo de la ortodoxia lo llevó a considerar el judaísmo como una religión superada.

No es casual que él, así como otro autor herético de la época, que insistió en las limitaciones del Talmud y en el carácter humano de la Biblia y que también vivía en Ámsterdam, Uriel Acosta, fuesen de origen marrano. Hijos de familias de judíos portugueses convertidos por la fuerza al cristianismo, ambos tenían una sensibilidad del mundo en el cual las visiones, sea del judaísmo o del cristianismo, aparecían como estrechas e irracionales, pues no permitían construir una filosofía que elaborase principios universales fundados en la racionalidad.

En su obra principal, el Tratado Teológico-Político, Spinoza concluye que la Biblia era una obra humana, escrita por múltiples autores, y muchos de sus contenidos son inaceptables y ofensivos a la moral. Moisés no sería un portavoz de Dios, sino un estadista que dio una constitución al pueblo judío. Si la Biblia fue escrita por seres humanos, debería ser leída en el sentido literal del texto y no como expresión de la palabra divina que contendría múltiples sentidos ocultos. El clero y los rabinos habrían creado un régimen de verdad al servicio del propio poder y ambición. Spinoza quería retirar de los rabinos y del clero el monopolio de interpretar correctamente el texto bíblico y dedicó los últimos años de su corta vida a 
elaborar una gramática de la lengua hebraica que permitiría a cada uno comprender el significado del texto bíblico.

El precio pagado por Spinoza por su osadía fue el Jerem (como en el judaísmo no existe excomunión, el Jerem prohíbe cualquier contacto de los miembros de la comunidad con la persona expulsada). Uriel Acosta sufrió suerte similar, pero intentó volver al seno de la comunidad. Esto le significó sufrir humillaciones, y, después de escribir sus memorias que denuncian la intolerancia, se suicidó.

Spinoza y Acosta fueron los pioneros de un movimiento que será característico de la modernidad: el de intelectuales, artistas, científicos y políticos judíos cuya obra se dirige a un público exterior, formado por una opinión pública culta, independiente de creencias religiosas. Se produce así el divorcio entre judíos y judaísmo, esto es, el origen judaico no implica que los autores desarrollen sus reflexiones en la tradición judaica, aunque ella pueda estar presente en mayor o menor medida.

El vector efectivo de los valores iluministas fue el estado nacional, que, a través de la noción de ciudadanía, creó una nueva categoría de personas iguales ante la ley, independientemente de las creencias individuales. Sucede que el estado nacional en Europa no surgió de la nada. Se construyó a partir de tradiciones de la cultura preexistente, el cristianismo. Así la integración de los judíos en el estado moderno y su aceptación efectiva como iguales, no fue automática ni completa. La posibilidad de ser excluido como un "extraño", como alguien que no pertenece a la cultura mayoritaria, aunque haya sido vivida con más intensidad en el pasado, cuando estaba asociada a la condición de migrante, continúa presente en la psique judía.

El problema del estado moderno era cómo “emancipar" los judíos, pues ellos hasta entonces vivían bajo tutela especial del rey. En la visión de los defensores de la causa judaica en la Revolución Francesa, la emancipación política de los judíos pasaba por la emancipación de éstos del judaísmo. Los "vicios" judaicos - que se referían a "hábitos alimentares repulsivos y misantropía - eran explicados como efecto del aislamiento al cual los judíos fueron condenados. Los filosemitas argumentaban que la integración en la sociedad permitiría una rápida "regeneración" del pueblo judío.
El proceso de adaptación del judaísmo a la modernidad implicó transformaciones internas pero también la exigencia de justificar su existencia ante el mundo exterior. Los filósofos de la historia, de Hegel a Spengler, orientados por una visión evolucionista que culminaba en la civilización cristiana occidental, consideraban una aberración la sobrevivencia del judaísmo. Para ellos, después de haber cumplido su papel histórico en el período bíblico, el judaísmo habría perdido su razón de existir. Una versión diferente fue elaborada por Stalin, que argumentó que faltaba a los judíos una de las características fundamentales para que pudiesen ser considerados una nación: un territorio común. Inclusive, en la sociología, que tuvo la sociedad nacional como objeto privilegiado de análisis hasta los años 1980, cuando irrumpe el tema de la globalización, el judaísmo era un fenómeno al cual casi no se podía aplicar sus teorías y conceptos que tenían como modelo sociedades nacionales territoriales.

Los judíos y en particular sus intelectuales se vieron obligados a responder a una doble exigencia, la de absorber valores modernos y al mismo tiempo justificar la continuidad del judaísmo. ¿Cómo y por qué seguir siendo judíos y mantener la lealtad con el estado nacional y los valores humanistas universales? Todas las versiones del judaísmo moderno tuvieron que elaborar respuestas a esta pregunta.

El problema fue planteado de forma explícita por Napoleón Bonaparte, el gran arquitecto del estado moderno francés. Él convocó un Sinedrio de representantes de la comunidad judía para responder a una serie de preguntas que permitirían confirmar si los judíos se disponían a aceptar las leyes del estado y ser leales a la patria. Napoleón aceptó las respuestas y a partir de él los judíos pasaron a ser "ciudadanos franceses de fe mosaica", identidad que se mantuvo sólida hasta la Segunda Guerra Mundial, a pesar de la sacudida sufrida por el "affaire Dreyfus". En él un capitán del ejército francés, Alfred Dreyfus, fue condenado en 1894 a prisión perpetua bajo acusación de espiar a favor de los alemanes gracias a un dossier falso. La lucha contra la condena, que llevó a Émile Zola a escribir el famoso J'accuse, llevó a la liberación del capitán (pero no a su rehabilitación en el cargo), pero indicó claramente que la política francesa no había eliminado a las fuerzas reaccionarias y anti-republicanas del catolicismo integrista.

El pasaje del judaísmo rabínico fue penoso para los judíos, pues, a pesar de las tendencias secularizantes, el estado nacional mantenía 
eslabones de continuidad con el mundo cristiano: el día de descanso continuó siendo el domingo, así como la mayoría de los feriados y el propio calendario (no es casual que el esfuerzo de la Revolución Francesa de romper con el pasado culminó con un calendario propio, ni que la fiesta popularmente más recordada por los judíos sea el Rosh Hashana, año nuevo, que señaliza la voluntad de auto-preservación por la afirmación de una temporalidad propia).

El caso francés, de un corte radical con el pasado por la fundación de la república, no tuvo paralelos en la historia europea. En la mayoría de los países, hasta la Primera Guerra Mundial, las monarquías mantuvieron en la cultura oficial del estado una simbología cristiana y grados variados de exclusión de los judíos de cargos públicos. No sólo en Rusia, donde el poder monárquico absoluto y una sociedad con trazos feudales usaron activamente el antisemitismo para canalizar el resentimiento popular, sino, inclusive, en el imperio Austro-Húngaro y en los varios principados alemanes y en el estado alemán arquitectado por Bismark, los judíos no podían, de hecho o de jure, ocupar posiciones en el servicio público. Como indica Max Weber en su conferencia sobre la vocación del sociólogo, a comienzos del siglo XX una posición en la academia era una aspiración fuera del alcance de un judío. Esto llevó a la conversión de muchos judíos, entre ellos los padres de Karl Marx, el poeta Heine y el compositor Mahler, para poder ascender socialmente.

Como veremos a continuación, la fragmentación del judaísmo fue múltiple, social, religiosa y política. Para las generaciones que vivieron este proceso, fue extremamente doloroso, confrontó padres e hijos, dividió comunidades y llevó a denuncias mutuas de estar destruyendo el judaísmo. Pero los temores se mostraron infundados, pues las divisiones revitalizaron el judaísmo.

\section{LAS CORRIENTES DEL JUDAÍSMO MODERNO}

as diversas corrientes del judaísmo moderno reflejan la variedad de realidades nacionales, políticas y socio-culturales de los diferentes países europeos y se expresaron a través de dos grandes vectores, el religioso y el político. En la arena religiosa, el cuestionamiento del judaísmo talmúdico tuvo como epicentro Alemania (que poseía la mayor concentración de judíos en Europa Occidental). Al contrario de Francia, donde la república otorgó la ciudadanía a toda la población, en Alemania, primero en los diversos principados y después en el país unificado bajo la égida de Prusia, se continuó discriminando a los judíos. Además, el flujo constante de judíos de Europa Oriental, pobres y vistos como culturalmente rudimentarios, provocaba en los judíos integrados en la cultura alemana sentimientos de incomodidad y eran vistos como una amenaza a su integración. La voluntad de distanciarse del judaísmo tradicional, de absorber los valores del iluminismo y de ser aceptados por la sociedad alemana llevó a los judíos alemanes, desde temprano, pero también a los de Dinamarca, Inglaterra y Austria, a reformar el judaísmo religioso.

En Europa Oriental y Rusia, el proceso de secularización tomó rumbos diferentes. Al contrario de Europa Central y Occidental, donde los judíos comenzaban a integrarse socialmente, en el Imperio Ruso (que incluía Polonia) no estaba en el orden del día la posibilidad de participar como ciudadanos en sociedades que eran autócratas y excluyentes. La estructura social de las comunidades judías también era diferente. En Europa Oriental, la mayoría de los judíos vivían en la pobreza y el conflicto social irrumpía entre judíos pobres y ricos. En este contexto, en lugar de reforma religiosa o cultural, prevaleció la reforma política y social. La cuestión judía sólo sería resuelta cambiando el conjunto de la sociedad o la situación social de los judíos, por la creación de un estado propio. En lugar de rabinos liderando el cambio, como ocurrió en Alemania, en Europa Oriental fueron intelectuales seculares, críticos de la religión, los que estaban al frente de los nuevos movimientos sociales.

Estos dos movimientos, uno en el sentido del cambio religioso, otro en el sentido de construcción de ideologías seculares con fuerte contenido político, fueron hasta cierto punto dinámicas paralelas, pero, con el 
transcurrir del tiempo, pasaron a yuxtaponerse. Esto porque, en el judaísmo, movimientos culturales locales rápidamente se irradian para otras comunidades y se inter-influencian mutuamente. Pero, a pesar de que las nuevas tendencias religiosas y políticas convergen, en el sentido de obligar a los religiosos a posicionarse frente a los movimientos políticos y viceversa, las relaciones entre ambas nunca fueron simples. Inclusive, como veremos, los judíos ultraortodoxos y los judíos reformistas durante varias décadas, por razones diferentes (los primeros para no colocar en cuestión la lealtad nacional, y los segundos porque continuaban apegados a la salvación divina), se opusieron inicialmente al sionismo.

Como indicamos, Alemania fue el principal palco de discusión sobre el aggiornamento por el cual el judaísmo debería pasar a integrar los valores modernos en sociedades mayoritariamente cristianas. El cuestionamiento del judaísmo tradicional, como no podría dejar de ser, tuvo como centro la legitimidad de la interpretación talmúdica.

El siglo XIX, un siglo donde irrumpe en Europa la creencia en el progreso humano, donde los cambios constantes indican que el pasado es diferente del presente y que el futuro es abierto, posicionó la historia como principal instrumento de explicación de los fenómenos sociales. Las sociedades pasaron a ser comprendidas como producto de quehacer humano y la historia como disciplina académica fue colocada al servicio de las grandes ideologías modernas: el nacionalismo, el liberalismo y el socialismo.

Surge así una serie de intelectuales que comienzan a contar la "historia del pueblo judío" a partir de relevamientos de fuentes históricas y análisis hermenéutica, y, de esta forma, inventan el judaísmo moderno, que pasa a verse a sí mismo como producto de la historia y de la acción humana y no de la voluntad divina. Se retoma de esta forma, sobre otros fundamentos teóricos, una visión similar al relato bíblico: el judaísmo es producto y se desarrolla en función de acontecimientos históricos.

Los intelectuales judíos pasaron a tratar la Biblia y el Talmud como textos históricos a los cuales se podían aplicar las modernas técnicas lingüísticas. En lugar de un todo coherente, identificaron en el Talmud múltiples escritores, períodos históricos y escuelas de pensamiento diferentes y conflictivas. Son enfatizadas las tensiones en el texto talmúdico entre los seguidores de Ravi Akiva, que habrían producido interpretaciones forzando excesivamente el sentido del texto bíblico y los seguidores de Rav
Ishmail que habrían buscado mantenerse más próximos al sentido original. Pero, sobre todo, de esta lectura surge una interpretación del Talmud como siendo un esfuerzo para legitimar innovaciones producidas en un contexto histórico especifico.

En suma, el Talmud, en lugar de ser un texto incuestionable, sería una adaptación creativa de nuevas prácticas al que los rabinos dieron un sentido sagrado relacionándolas al texto bíblico. Lo que inicialmente fue una crítica a la legitimidad de las interpretaciones talmúdicas terminó llevando a una nueva visión del lugar de los talmudistas en el judaísmo. Los rabinos que produjeron el Talmud podían ser vistos como intelectuales altamente creativos en su época, pero que canonizaron tradiciones datadas históricamente. Mantener el ejemplo de los rabinos talmúdicos implicaría una nueva interpretación de la Biblia, adecuada a los tiempos actuales.

El primer gran movimiento en esta dirección fue el Reformista (llamado Liberal en Inglaterra). Este movimiento procuró transformar el judaísmo en una religión de la cual se intentó eliminar los contenidos nacionales y buena parte de las reglas construidas en torno del principio de lo puro/impuro, oraciones diarias y bendiciones constantes y descanso sabático. La esencia del judaísmo estaría en los valores éticos expresados en la Biblia y su papel debería ser el de contribuir a la mejora de la humanidad.

Junto con las transformaciones discursivas también fueron transformadas las prácticas religiosas. Seguir los mandamientos tradicionales asociados a las reglas de lo puro/impuro dejó de ser obligatorio. Hombres y mujeres pasaron a sentarse y rezar juntos en la sinagoga, que pasaron a usar órganos (inspiradas en templos protestantes) y las oraciones dejaron de ser hechas en hebreo para usar la lengua local. El esfuerzo por integrarse al discurso liberal y a la ciudadanía nacional llevó a los reformistas a disociarse de los componentes místico-nacionales del judaísmo, dando a la llegada del Mesías un sentido ético-universal.

En el transcurso del tiempo, el judaísmo reformista fue cambiando. En la segunda mitad del siglo XX, asumió más las dimensiones étnicas, apoyó al sionismo y pasó a valorar el uso de la lengua hebraica. A su vez, integró nuevas tendencias culturales, formando mujeres rabinas y aceptando el homosexualismo. El judaísmo reformista es hoy la principal corriente religiosa en Estados Unidos y presenta una enorme variedad de versiones. 
Cada rabino y sinagoga tienen sus propias peculiaridades, de acuerdo con las características de la comunidad local.

La segunda línea de renovación religiosa fue el judaísmo Conservador (el nombre no tiene nada que ver con una ideología política, sino con el deseo de conservar las tradiciones y distinguirse de los reformistas), cuyas bases intelectuales fueron desarrolladas en Alemania, pero, como movimiento religioso, es fundamentalmente un fenómeno estadounidense. Buscó combinar el tradicionalismo de los inmigrantes judíos de Europa Oriental con los valores modernos. Cree en el carácter divino de la Torah, mantiene el uso del hebreo en las oraciones, pero reconoce la naturaleza histórica de las innovaciones talmúdicas, aunque el Talmud continúe siendo una referencia central. Practica los mandamientos sobre kashrut y descanso en el día sábado, pero con grados de tolerancia bastante amplios. En ciertas áreas ha introducido cambios profundos, en particular en la aceptación de la igualdad de la participación de la mujer en los rituales religiosos, inclusive consagrándolas como rabinas y en la búsqueda de integrar valores de justicia social universal. El movimiento conservador siempre apoyó al sionismo.

Por largo tiempo, el conservadorismo fue la principal corriente religiosa en Estados Unidos, pues funcionó como un puente adaptativo entre la religiosidad tradicional de los inmigrantes de Europa Oriental y el Nuevo Mundo. Pero, en las últimas décadas, fue perdiendo espacio para el judaísmo reformista y para otras tendencias renovadoras. Hoy, vive dilacerado entre un liderazgo más conservador que busca limitar los cambios y el apego a la tradición talmúdica por un lado y a la presión de las bases por una mayor apertura por otro. Algunas innovaciones, como el EcoKosher, inicialmente introducida por el Rabino Arthur Waskow, del movimiento Renewal, que busca asociar la comida Kasher con las condiciones sociales y ecológicas de la producción, han generado conflictos con los judíos ortodoxos.

A estas corrientes se debe agregar el judaísmo Reconstruccionista, inspirado por el rabino Mordechai Kaplan, una de las grandes figuras del judaísmo del siglo XX, y que oscila entre la corriente conservadora y la reformista. En las últimas décadas, parte de la creatividad del judaísmo religioso migró de los grandes centros institucionales a movimientos relativamente marginales, como el liderado por el rabino Zalman $\mathrm{M}$.
Schachter-Shalomi, del movimiento Renewal, la revista Tikun, y centenas de sinagogas donde se experimentan nuevas formas de religiosidad judaica.

La fragmentación del judaísmo religioso se dio también en el interior del campo de la ortodoxia, que se separó de la llamada ultraortodoxia o Jaredim (temerosos de Dios). Desde el siglo XIX, en Alemania, una parte de los judíos ortodoxos concluyó que debía realizar un esfuerzo de adaptación a la vida moderna, integrando en la enseñanza las disciplinas científicas, participando de la vida universitaria y aceptando algunos valores y estilos de vida modernos. Una parte de ellos apoyó y pasó a participar activamente del movimiento sionista. Hoy el judaísmo ortodoxo constituye un universo internamente fragmentado, donde conviven tradiciones diferentes (por ejemplo, la originada en occidente y la oriunda del mundo musulmán) y en Israel se encuentra políticamente dividido, desde críticos de la ocupación que defienden los derechos humanos y, la gran mayoría, que se posiciona en la derecha nacionalista.

Diversidad similar puede ser encontrada en el mundo ultraortodoxo, que se recusa a integrar los valores de la modernidad. Pero, aún así, en el siglo XX, las mujeres pasaron a tener acceso a la educación formal, aunque no a los centros de estudios avanzados de la Torah (aunque continúen teniendo un status disminuido, no pudiendo ser testigos en procesos, ni cumplir una parte de los mandamientos, siendo todavía consideradas las únicas responsables por la infertilidad de la pareja).

El campo ultraortodoxo es enormemente variado. En Israel, los mizrajim (judíos provenientes del mundo árabe), se alejaron de la hegemonía de las yeshivot - centros de estudio y formación rabínica -, de origen ashkenazi y montaron sus propios centros. Existen grupos jasídicos y opositores a ellos. Las varias sectas jasídicas mal se hablan entre sí. En general, los grupos ultraortodoxos se mantienen distantes del sionismo y existen los que no reconocen la existencia del Estado de Israel y lo consideran una aberración que aleja la venida del Mesías y otros que participan de la vida política del país y procuran avanzar en sus intereses e imponer su visión religiosa al Estado.

En el interior de la ultraortodoxia, ocupa un lugar particular la corriente jasídica Luvabitch, que mencionamos anteriormente. A partir del liderazgo del último rabino, radicado en Nueva York, Menajem Mendel Schneerson, los Luvabitch pasaron a tener una actividad misionera, también 
nueva en la tradición judaica, procurando atraer los judíos a la práctica religiosa, como forma de acelerar la llegada del Mesías (que para muchos miembros del movimiento era el propio Reve Schneerson). Los Luvabitch envían sus misioneros a todos los rincones del mundo donde viven judíos, debiendo quedarse en esos lugares en forma permanente o hasta la llegada del Mesías. El proselitismo Luvabitch es extremamente creativo, pues junta la ultraortodoxia con una gran apertura en relación a judíos distantes de la religión (pues, como mencionamos, ellos creen que todo judío carga una chispa divina), usando medios electrónicos y la celebración del judaísmo en lugares públicos. La enorme capacidad de movilizar recursos y redes sociales para apoyo de judíos necesitados y la disposición misionera tiene como contracara su tendencia anti-pluralista, en particular en países con comunidades judías menores. Aunque no asuman una posición directa en relación al sionismo, se oponen a cualquier concesión territorial alineándose de hecho con la derecha nacionalista.

En su conjunto, los grupos religiosos ortodoxos y ultraortodoxos constituyen una minoría dentro del judaísmo, 10\% en Estados Unidos y $20 \%$ en Israel, donde han crecido en particular por las altas tasas de fertilidad.

Los judíos seculares, entendidos como una amplia corriente que se identifica con el judaísmo como una cultura y/o historia común, sin referencia a la creencia en textos sagrados, es la corriente mayoritaria en el judaísmo. Los intelectuales y movimientos sociales seculares procuraron una respuesta a la integración del judío o judaísmo en la sociedad moderna fuera de la religión. Algunos, inclusive, fuera del propio judaísmo, en el movimiento comunista, que prometía la redención de la humanidad. Las otras dos grandes tendencias, el Bund y el sionismo, elaboraron versiones nacionalistas.

El Bund congregó a los trabajadores judíos de Europa Oriental y, gracias a las tradiciones judías de solidaridad y fuerte cohesión social, se transformó, a comienzos del siglo $\mathrm{XX}$, en el principal partido socialdemócrata del imperio zarista (Polonia, Lituania y Rusia). El Bund consideraba que la lengua y la cultura Idish (una lengua derivada del germánico, con gran número de expresiones de otros países de Europa oriental y del hebreo, usando en la escritura las letras hebraicas) sustentaban una identidad nacional judía y exigían la autonomía cultural al interior de los países en que vivían. Debemos recordar que en Europa oriental el Idish era la lengua franca de la casi totalidad de los judíos y en torno de él gravitaban centenas de teatros y periódicos, producción de películas, una vasta producción literaria y casas editoriales que tradujeron un impresionante número de obras científicas y literarias. Después de la Revolución Rusa, que implantó la dictadura del partido comunista y proscribió todos los partidos políticos, una parte de los miembros del Bund adhirió al comunismo.

El Holocausto destruyó la base social del Bund en Polonia, donde continuó siendo una fuerza social importante hasta la Segunda Guerra Mundial. Muchos inmigrantes bundistas recrearon el movimiento en el Nuevo Mundo, donde, en la primera mitad del siglo XX, en particular en América Latina, en Estados Unidos, Canadá, Australia y Europa Occidental, mantuvo centros culturales, escuelas y un fuerte activismo en la política local. El ocaso del uso del Idish en el Nuevo Mundo, la ascensión social de los judíos, el antisemitismo de la última fase de Stalin, el surgimiento del Estado de Israel y la política pro-árabe de la Unión Soviética lo debilitaron enormemente. Pero, en varios lugares, muchas de sus escuelas y centros culturales se fueron adaptando a los nuevos tiempos y son actores importantes en la promoción del judaísmo secular.

El sionismo, la otra gran corriente del judaísmo secular, se inspiró en el nacionalismo europeo del siglo XIX como solución al problema del antisemitismo, que, para los sionistas, era inmanente a la vida en la diáspora. Mayoritariamente secular, rechazó la espera de los tiempos mesiánicos y puso en el centro de su visión del mundo al judaísmo como fenómeno histórico y la política como medio para transformar el destino del pueblo. Su objetivo fundamental era "normalizar" el pueblo judío, transformándolo en una nación igual a las otras, por la construcción de un estado en la tierra de Israel. Se organizó en torno a partidos políticos que incluían grupos marxistas-leninistas, laboristas (el grupo hegemónico), liberales y de derecha nacionalista. Las consecuencias históricas del movimiento sionista serán discutidas en un próximo capítulo.

¿Cuáles son las características comunes del judaísmo secular? El judaísmo secular puede ser caracterizado, de forma sintética, por los siguientes elementos:

1. Separó la identidad judaica de la religión. Esta separación, sin embargo, como veremos, nunca fue completa, manteniendo una ambigüedad en relación a las tradiciones de origen religioso. 
2. Procuró legitimar el judaísmo por los valores modernos, mostrando que el mismo es capaz de convivir y expresarse en términos "universales".

3. Estuvo encuadrado por los grandes movimientos ideológicos de su época - liberalismo, socialismo y nacionalismo -, que creían que podrían ser construidas sociedades sustentadas en proyectos orientados por la racionalidad. Esto creó un estilo doctrinario, discursivo, lógico, celoso de una coherencia fundada en la capacidad de sintetizar judaísmo con modernidad, que reprimió o por lo menos ocultó, las dificultades de integrar las dimensiones no racionales, ritualísticas, trascendentales, asociadas a la identidad y cultura judía heredada de la época talmúdica.

4. A nivel personal, fue vivido como una crisis de identidad, dividido entre tradición y modernidad, entre lealtad a los lazos primarios y al conjunto de la sociedad nacional y a la humanidad, entre lo privado y lo público, entre sentimiento y razón.

\section{SEGUNDA PARTE:}

\section{EL JUDAÍSMO CONTEMPORÁNEO}




\section{HOLOCAUSTO, MEMORIA Y POLÍTICA}

$\mathrm{E}$

1 Holocausto no sólo quitó la vida de seis millones de personas, como destruyó los mayores centros de cultura judía, tanto religiosa como secular. Erosionó la creencia de los judaísmos modernos en la posibilidad de un mundo guiado por la razón y llevó a un apoyo masivo al sionismo, hasta entonces una de varias corrientes del judaísmo. Mudó la distribución geográfica de los judíos en el mundo, transformando a Estados Unidos en el principal centro demográfico en la diáspora y fue un factor importante en la creación del Estado de Israel. Pero, el efecto más perturbador en los tiempos actuales es que hasta hoy el judaísmo, de forma explícita o implícita, vive a la sombra del Holocausto.

El Holocausto ciertamente continuará afectando por largo tiempo al judaísmo y los judíos y como todo trauma histórico, su superación llevará generaciones para que pueda ser asimilado. Sin embargo, la dimensión que él adquirió como referencia central y muchas veces casi exclusiva de la identidad judaica contemporánea, sofoca y empobrece la memoria colectiva.

La elaboración del Holocausto exige un esfuerzo enorme para recuperar la memoria del mundo cultural que fue destruido. El mayor monumento que se puede hacer por la memoria de los muertos es recordar la vida que ellos llevaban, la riqueza del universo que ellos expresaban. Precisamos de más museos que junto con los testimonios terribles de la máquina de muerte nazista nos muestren la riqueza cultural del mundo que fue destruido, sobreponiendo la vida a la muerte, indicando junto con el nombre y el número de muertos de cada comunidad la vitalidad de las instituciones y centros de estudio y de vida artística destruidos. Se trata de una tarea difícil, pues en Israel el Holocausto fue transformado en un símbolo de las dimensiones negativas de la diáspora y en las comunidades judías diaspóricas el Holocausto es utilizado para transmitir a las nuevas generaciones la identificación con el judaísmo por el miedo de su repetición. En ambos casos existe poco interés en el mundo que el Holocausto destruyó y de que forma puede ser continuado y renovado.

El efecto más profundo del Holocausto en la psique judaica fue la “lección' de que el destino de los judíos depende de sus acciones y no de la ayuda divina. En este sentido específico, transformó la gran mayoría de los judíos en "ateos": independientemente de creer o no en Dios, pocos judíos, aún ortodoxos, después del Holocausto, creen que pueden depender de Dios en momentos de peligro. El Holocausto creó una nueva alianza, en la cual Dios fue excluido o, al menos, está ausente, entre los más diversos tipos de judaísmo y judíos, una alianza en torno a la memoria y a la solidaridad.

Esta visión saludable de la historia a veces se expresa en un discurso de que los judíos están solos y sólo pueden confiar, en momentos de peligro, en otros judíos. Ella es una versión secular de la narrativa construida por la religión, que valoriza los momentos de persecución y sufrimiento colectivo. Esta visión está presente en varias festividades, no solamente en los eventos que recuerdan hechos tristes, como la destrucción del primer y segundo Templo, pero también en la fiesta más alegre, Purim (el "carnaval" judío) que festeja la intervención de la reina Esther junto al rey persa Assuero, para cancelar el edicto del primer ministro Haman que pretendía eliminar todos los judíos del reino. En suma, la gran alegría es que los judíos no hayan sufrido un genocidio.

Se trata de una perspectiva errónea tanto desde punto de vista moral, político e histórico. Moralmente falso, porque olvida la cantidad de nojudíos que pusieron sus vidas en riesgo para salvar judíos. Históricamente errónea, porque el pueblo judío siempre dependió de alianzas para sobrevivir o realizar sus proyectos, sea en el retorno del exilio de Babilonia y la reconstrucción del segundo Templo, posibilitados por decretos de los reyes persas, sea en la creación del Estado de Israel, que contó con el voto mayoritario de la comunidad internacional o en las guerras que el país enfrentó, cuando recibió armas del bloque soviético, después, de Francia y, finalmente, de Estados Unidos. La visión de aislamiento, de estar solos en el mundo, es políticamente peligrosa, porque, sea como minoría en la diáspora, sea como Estado de Israel, la capacidad de autodefensa siempre dependerá de alianzas y apoyos los más amplios posibles. La capacidad de movilizar estos apoyos fue y continúa siendo una de las principales condiciones de sobrevivencia de los judíos.

La memoria es nuestra condición de humanidad, pero también la principal fuente de sufrimiento. Somos nuestros recuerdos. Memorizar es recortar el pasado, olvidar casi todo para poder recordar ciertos eventos y darles un significado determinado. Si la memoria nos enraíza, dando un sentido de continuidad a nuestras vidas como individuos y como miembros 
de una comunidad, ella también oprime. Nos quita libertad, nos obsesiona, transforma situaciones de aprendizaje en experiencias traumáticas y resentimientos, aprisionándonos en el pasado. Pero, si no existe presente sin pasado, el pasado siempre es vivido e interpretado a la luz de las realidades del presente. Si la memoria no es aleatoria ni totalmente maleable, ella es constantemente rehecha y palco de conflictos (dentro de cada individuo y entre grupos sociales). La preservación de la memoria es siempre un ejercicio de poder, de la capacidad de imponer una interpretación del sentido del pasado.

El Holocausto es un caso ejemplar de usos y abusos de la construcción de una memoria colectiva. El pasaje del sufrimiento absoluto, vivido por todos aquellos que sufrieron directa o indirectamente el Holocausto, a una narrativa sobre su significado no es una línea recta y exige un esfuerzo constante de vigilancia y reflexión. Discutir y cuestionar los usos políticos dados al Holocausto es un ejercicio difícil y delicado, más aún de frente a quienes lo niegan y particularmente de una estrategia de propaganda iniciada por Irán y hoy difundida por muchos grupos propalestinos. Esta estrategia busca deslegitimar el derecho de existencia del Estado de Israel asimilando las prácticas del ejército israelí con las de los nazistas. Las palabras no son ingenuas, y deshumanizar al adversario es el primer paso para justificar su destrucción.

Esta situación produce reacciones defensivas que dificultan una discusión ponderada sobre el sentido actual del Holocausto. Pero sin esta discusión se queda a merced de que sea usado por los líderes en la diáspora y en Israel, que utilizan la tragedia para justificar agendas políticas y culturales específicas. En ambos casos, en Israel y en la diáspora, fue construido en torno del Holocausto un discurso sobre su excepcionalidad histórica. El tema que se plantea no es si él fue o no un fenómeno único (cuestión sobre la cual los historiadores y científicos sociales tendrán posiciones diferentes), sino del significado moral y político que se busca dar a esta excepcionalidad. Desde el punto de vista moral, enfatizar la excepcionalidad del Holocausto es insostenible, porque el sufrimiento humano producido por genocidios es inconmensurable. Políticamente, porque si el Holocausto fue una excepción, entonces podemos lamentarnos sobre lo sucedido, pero él es irrelevante para las nuevas generaciones. El Holocausto, por el contrario, tiene mucho a enseñar, porque él no fue una excepción, sino el producto del odio, de la intolerancia, de la negación de la humanidad y demonización de quien es diferente. Estas tendencias destructivas están siempre presentes en toda sociedad y el Holocausto es un símbolo de las consecuencias terribles del potencial destructivo de ideologías y regímenes políticos que se sustentan en el fanatismo y en la negación de la humanidad del otro.

Paradojalmente, al mismo tiempo en que enfatizan su excepcionalidad histórica y los líderes comunitarios se irritan cuando se banaliza el uso de la palabra Holocausto, muchas veces esto es hecho por algunos grupos judíos, como en las manifestaciones de la derecha israelíes con imágenes de Itzhak Rabin vistiendo el uniforme de un oficial de la SS o para denominar como Holocausto cultural procesos de integración voluntaria de los judíos en sus sociedades.

No permitir que el Holocausto sea vinculado a agendas políticas no significa que no se deba luchar para preservar su memoria y luchar contra revisionismos históricos que cuestionan el genocidio nazista o lo utilizan para propaganda política anti-israelí. Por el contrario, condenar todos los usos políticos del Holocausto es una pre-condición para que él pueda ser comunicado como una tragedia humana de proporciones catastróficas y que su memoria esté al servicio de valores humanistas.

Mantener la memoria y divulgar el Holocausto en el mundo, para que él no se repita con los judíos y ningún otro pueblo, exige un esfuerzo constante de lucha contra las viejas y nuevas formas de intolerancia y persecución. En la época en que vivimos, donde el discurso de la victimización es dominante, el énfasis en la excepcionalidad del Holocausto lo coloca en competencia con otras víctimas. Esta competencia lleva a cada uno a mirar su propio ombligo, en lugar de promover una visión que unifique todas las víctimas en torno de un ideal humanista. Es fundamental un diálogo que muestre que el Holocausto no es un fenómeno que se refiere a los judíos sino a todos los grupos estigmatizados, que solamente instituciones democráticas y el respeto por todas las culturas pueden asegurar la sobrevivencia y dignidad de las diferentes minorías. 


\section{EL ESTADO DE ISRAEL}

D ara una generación que todavía tenía viva la memoria de los progroms de la Europa Oriental y del Holocausto, la creación del Estado significó una experiencia y una emoción irreproducible. Cuando pregunté a mi padre - hijo de rabino y que perdió toda su familia en el Holocausto - si todavía creía en la llegada del Mesías, me respondió que para él ya había llegado, en la forma del Estado de Israel.

El Estado de Israel devolvió la dignidad a una generación abatida, pero también a un pueblo que vivió dos mil años de vida insegura en la diáspora, sin posibilidades de autodefensa frente a la violencia exterior. El grito del levantamiento del gueto de Varsovia, "no iremos como corderos al matadero", se personificó en la figura del soldado israelí.

El enfrentamiento de los ejércitos árabes en la lucha por la independencia en 1948-1949 resucitó la imagen de David enfrentando a Goliat y la de los Macabeos. La valoración del trabajo de la tierra recuperó el auto-respeto de un pueblo al cual la diáspora había retirado del contacto con la naturaleza. El Kibutz - uno de los pocos experimentos exitosos de comunismo con libertad -; un país democrático e igualitario que tenía un movimiento laborista que controlaba una parte importante de la economía; una agricultura sustentada en formas cooperativas o colectivas de trabajo; una vibrante vida científica; todo eso era fuente profunda de orgullo. La nueva cultura judía secular promovida en particular por los kibutzim, revalorizó en las fiestas judías su relación con las fases del trabajo agrícola y los símbolos religiosos dieron lugar a símbolos nacionales y seculares.

En estos sesenta años de existencia del Estado de Israel esta realidad cambió y muchas de estas imágenes perdieron fuerza. Con el desarrollo económico, la sociedad israelí fue adquiriendo un carácter más urbano y capitalista, corroyendo así el sentido agro-pastoril y trabajador que la cultura colonizadora procuró dar a las festividades y valores judaicos. Los kibutzim pasaron por una profunda crisis y si bien consiguieron sobrevivir adaptándose a las nuevas circunstancias, perdieron su peso simbólico y la sociedad israelí, a partir de los años setenta, pasó a ser cada vez más desigual. La democracia todavía se sustenta y en varios aspectos es ejemplar, pero, sesenta años de guerra y más de cuarenta años de ocupación, envenenaron el alma y las instituciones, en particular en lo que se refiere al respeto de los derechos de la minoría árabe-israelí y, más aún, a la población de los territorios ocupados en la guerra de los seis días (1967).

¿Qué sucedió? Israel sufre una doble crisis, ambas convergentes y que se refuerzan mutuamente. Una crisis moral, producto de la ocupación de los territorios palestinos después de la guerra de 1967 y una crisis de identidad en relación al significado del judaísmo.

La relación de Israel con el mundo islámico, en particular con la población palestina y sus vecinos, nunca fue simple, desde el inicio de la colonización sionista. La llegada de los judíos era vista como una incursión europea en el mundo árabe. Para los judíos, se trataba de retornar a la tierra con la cual mantuvieron un vínculo durante dos mil años y donde siempre tuvieron una presencia, a no ser en los períodos en que fueron expulsados de ella. La sensibilidad de la mayoría de los líderes sionistas en relación a los sentimientos de la población árabe dejó siempre que desear, y, a su vez, los liderazgos palestinos y árabes siempre anunciaron la voluntad de expulsar la población judía y posteriormente destruir el Estado de Israel.

En tanto defendían el derecho a su existencia dentro de las fronteras generadas por la guerra de independencia, las acciones del ejército de Israel eran legítimas y apoyadas por buena parte de la opinión pública occidental. Pero, la conquista de Cisjordania, Gaza y el Golán en la Guerra de los Seis Días creó la ilusión, inicialmente de los gobiernos laboristas y posteriormente de derecha, de que sería posible mantener indefinidamente el control de esos territorios y colonizarlos gracias a la polarización del mundo en la época de la Guerra Fría.

La conquista y colonización llevaron a una situación de deterioro moral, de debilitamiento de la democracia, actos ilegales, desperdicio de enormes recursos económicos, distorsión de la capacidad estratégico-militar, pérdida de vidas, desvío del objetivo de construcción de un Estado mayoritariamente judío y abandono del apoyo de la opinión pública internacional.

Obsérvese que esta lista no incluye los enormes costos que la ocupación tuvo para el pueblo palestino. No es que ellos no deban ser contabilizados. Pero mi argumento es auto-centrado a propósito: la ocupación 
y la colonización fueron nefastas para el Estado de Israel y produjo enormes dilemas morales para aquellos que se sienten comprometidos con su destino.

La ocupación es inmoral, deshumaniza y embrutece, pues ella sólo se sustenta en el esfuerzo permanente de opresión del ocupado. La ocupación atenta contra la democracia, transformando parte de la población en nociudadanos, sobre los cuales todo arbitrio es posible y fortalece grupos judíos-israelíes radicales que se consideran encima de la ley. La ocupación es ilegal, pues desconoce todas las decisiones de la comunidad internacional e hiere el principio de la autodeterminación de los pueblos, sobre el cual se construyó el orden internacional después la Segunda Guerra Mundial. La ocupación representa un desperdicio enorme de recursos económicos en la construcción de infraestructuras, vivienda y seguridad para los colonos, en tanto, en el Estado de Israel, parte de la población vive en la pobreza.

La ocupación transformó el ejército de Israel en policía represiva, desviándolo de su papel de defensa contra ataques de ejércitos enemigos, afectando su capacidad estratégico-militar y la moral de los combatientes. La ocupación coloca en jaque la construcción de un Estado con mayoría judía, pues, caso ella sea permanente, transformará la población judía en una minoría. La ocupación significó la pérdida inútil de innumerables vidas humanas, ya que ellas no fueron sacrificadas en defensa de la patria. La ocupación llevó a una enorme caída del apoyo de la opinión pública internacional ya que sus objetivos son indefendibles.

La ocupación y la colonización crearon un enorme dilema moral y político para los judíos humanistas, que apoyan el Estado de Israel y se identifican con su destino. Críticos de la política de ocupación, al mismo tiempo, no quieren hacerle el juego al enemigo, de aquellos que tienen posiciones claramente antisemitas y/o no aceptan el derecho a la existencia de un Estado de mayoría judía conviviendo lado a lado con un Estado palestino. Tachados por algunos líderes comunitarios como judíos movidos por auto-odio, en verdad todos los que luchan - en Israel y en la diáspora contra la ocupación, sin ilusiones románticas sobre las dificultades a recorrer en el camino de la paz o sobre las intenciones de muchos líderes árabes, en lugar de sufrir del síndrome de auto-odio, contribuyen para la consolidación del Estado de Israel.

La crisis moral producida en Israel por la ocupación converge con y amplificó otra crisis, relacionada con el sentido de la identidad judía de
Israel. Sentido que estaba lleno de ambigüedad en los pioneros e ideólogos del sionismo. En sus orígenes, el sionismo fue un esfuerzo explícito, por parte de judíos seculares, de "normalizar" el pueblo judío, creando un hogar nacional que sería el único refugio seguro contra el antisemitismo. La diáspora era considerada una anomalía, fuente de sufrimientos que debería desaparecer por la concentración de los judíos en un estado nacional, en un proceso similar al de los otros pueblos europeos de la época. No sólo la diáspora era considerada un período oscuro de la historia judía, como su memoria debía ser borrada para que pudiese surgir un nuevo pueblo, sin los traumas del pasado. No es exagerado definir la visión sionista de los dos mil años de permanencia de la diáspora como siendo una "generación del desierto" (la generación que salió de Egipto y que necesitó perecer durante la peregrinación de cuarenta años por el desierto, para dar lugar a una generación que no cargaba la marca de la esclavitud).

El sionismo y los colonos de Israel procuraron crear una nueva cultura judaica sobre nuevas bases, seculares, que desconocían prácticamente los dos mil años de exilio - presentado como un período puramente negativo de persecuciones y humillaciones. El esfuerzo para crear un "nuevo hombre" fue colosal. El sionismo conscientemente combatió las lenguas diaspóricas y resucitó el hebreo como lengua cotidiana (enfrentando aquellos que preferían el Idish o el alemán). Desarrolló una versión de la historia judía, centrada en la tierra de Israel y en el período bíblico hasta el Segundo Templo. Valoró el trabajo físico, el "retorno a la naturaleza" y creó una cultura secular que enfatizaba las dimensiones del ciclo natural y agro-pastoril de las festividades religiosas.

La gran mayoría de los sionistas estaba alejada de la religión, que era vista como llevando a la resignación y a la pasividad en espera de la llegada de los tiempos mesiánicos. No es casual que haya sido elegido como letra del himno nacional (el Hatikva) un texto en que Dios no es mencionado, en competencia con otras propuestas de letras retiradas de los Salmos.

Como todo sueño realizado, el sionismo se mostró acertado en ciertas cosas y errado en otras. Como en toda ideología política, focalizó unilateralmente ciertos temas y reprimió otros. Esto, sin considerar que las condiciones históricas en que el sionismo surgió son muy diferentes de las actuales y debemos resguardarnos de lecturas anacrónicas. 
El sionismo se equivocó profundamente en relación a la evaluación de la importancia de la diáspora para la sobrevivencia del judaísmo. La ideología que se instaló en el Estado de Israel, contrapone la capacidad de autodefensa de los israelíes a la situación indefensa en que los judíos se encuentran en la diáspora. Es una falsa oposición. Sin duda, la existencia del Estado de Israel fue y podrá ser fundamental para muchos judíos perseguidos y ayudó a fortalecer el sentimiento de dignidad y la disposición de autodefensa de los judíos en la diáspora. Pero, sea un estado pequeño, como el Estado de Israel o las comunidades en la diáspora, siempre deberán contar con apoyos externos. El propio Estado de Israel tiene en la diáspora un apoyo fundamental.

La propia condición diaspórica de los inmigrantes limitó el proyecto de "normalización" del judaísmo en Israel. La idea de crear una cultura israelí como una obra de ingeniería social que desconocía los orígenes culturales de cada ola de inmigrantes era irrealista. La sociedad israelí refleja el mosaico de culturas nacionales del judaísmo diaspórico. En realidad la cultura israelí estuvo marcada siempre por los orígenes locales de los migrantes. La primera ola de inmigrantes de Europa Oriental trajo de allá tanto el socialismo como la música. Posteriormente, cada grupo vino con sus tradiciones de origen, que hacen de Israel un archipiélago cultural. Inmediatamente después de la creación del Estado de Israel, vino la migración masiva de los países musulmanes, trayendo una religiosidad y valores religiosos tradicionalistas y hoy parte de ellos apoya un partido político, el Shas, que defiende los intereses corporativos de esta población dentro de una visión política religiosa conservadora. La reciente migración de más de un millón de judíos de la ex-Unión Soviética creó una comunidad que continua ligada a abandonar la cultura rusa, donde sus integrantes se organizan en partidos políticos propios, en general seculares de derecha. Y, de forma más difusa, cada grupo de inmigrantes mantiene organizaciones y sociabilidad propias, incluyendo los latinoamericanos. A su vez, centenas de millares de israelíes que dejaron el país recrearon una diáspora con características propias.

El conflicto con el mundo árabe y la necesidad de apoyo del judaísmo de la diáspora inviabilizaron la posibilidad del desarrollo de una cultura israelí "separatista", diferenciada del judaísmo "galútico" (del exilio), a pesar de algunas iniciativas en este sentido. Seguramente, con la llegada de la paz, las tensiones y distancia entre la diáspora e Israel tenderán a aumentar. La sensibilidad y orientaciones psico-culturales desarrolladas en la diáspora no son las mismas que en Israel y a veces los intereses pueden ser divergentes.

Sin duda, se trata de un estado joven, que todavía deberá pasar por muchas generaciones para destilar una nueva cultura nacional. Pero, los tiempos actuales, de globalización, difícilmente permitirán repetir los procesos que en los siglos XIX y XX llevaron a la constitución de culturas nacionales auto-centradas. El multiculturalismo será una característica de la cultura israelí. Esto sin mencionar el lugar importante que la cultura árabeisraelí deberá tener después del fin del conflicto.

El futuro del judaísmo en Israel depende de su capacidad de redefinir las relaciones entre religión y estado. El Estado de Israel entregó a los judíos ultraortodoxos el control de parte de la justicia civil (casamientos, divorcios y administración de los cementerios públicos) y el derecho de decidir quién es judío en los documentos de identidad (aunque no para emigrar a Israel, que fue definido por la Corte Suprema de Justicia, como incluyendo cualquier persona que posea abuelo de origen judío). De esta forma, los hijos de Theodor Hertzl, considerado el "padre de la patria", podrían migrar a Israel como judíos, pero allá no serían definidos como tales, pues la esposa de Hertzl tenía una madre no judía.

El origen de esta situación se encuentra en decisiones de los primeros gobiernos de favorecer el judaísmo ultra-ortodoxo para mantener viva la tradición religiosa destruida por el Holocausto y en la dinámica política de un país gobernado por coaliciones partidarias de las cuales los partidos religiosos forman parte a cambio de privilegios. Pero la fuente original del problema posiblemente se encuentra en la cultura de los pioneros que crearon el Estado de Israel, oriundos mayoritariamente de Europa Oriental. Ellos reaccionaron contra la cultura talmúdica, rompiendo radicalmente con ella, al contrario del judaísmo alemán y de Estados Unidos, que reelaboraron y modernizaron la práctica de la religión judaica. Así, el sionismo no vehiculizó una visión moderna de la religión judía, simplemente pensó que ella pertenecía al pasado. Al mismo tiempo, la religión judaica era identificada con la ortodoxia, pues los movimientos reformista y conservador sólo recientemente comenzaron a tener una presencia relevante, aunque pequeña, en Israel.

Si bien existan en Israel importantes núcleos de judíos ortodoxos liberales, la mayoría de los ortodoxos busca imponer su visión sobre el 
conjunto de la población y, en su mayoría, son parte del campo nacionalista, opuestos a la devolución de los territorios palestinos. En las últimas décadas, ellos han aumentado su peso relativo en la población israelí, y buena parte de ellos pasaron a girar en la órbita de un mutante, el judaísmo ortodoxo nacionalista-extremista.

Un grupo de judíos religiosos, ya en Europa de la primera mitad del siglo XX, se identificó con el sionismo, creando posteriormente un partido, Mizrahi, inicialmente aliado al partido laborista, pero que, en las últimas décadas, se orientó cada vez más hacia posiciones ultranacionalistas. La mayoría de los grupos ultraortodoxos se opuso al sionismo y a la creación del Estado de Israel. Después de la independencia, organizaron el partido Agudat Israel que pasó a hacer parte de coaliciones gubernamentales, a partir de las cuales presionan por privilegios para sus representados (entre ellos, no hacer servicio militar) y por la imposición de leyes religiosas al conjunto de la población.

Inicialmente justificada en nombre de la seguridad nacional, la ocupación cada vez más pasó a ser mezclada con "derechos bíblicos". La propia ocupación hizo renacer en grupos ortodoxos una tendencia, adormecida por dos mil años, a la militancia política. Buena parte de los colonos y sus líderes están asociados a visiones religiosas ortodoxas y ultraortodoxas, que reivindican el derecho al territorio bíblico, transformando un conflicto de nacionalismos en un conflicto religioso. Nada más peligroso: intereses son negociables, creencias no.

Cuando la ortodoxia se asocia y manipula el poder político, las consecuencias son lamentables y dramáticas. Los colonos ortodoxos usan la violencia física contra la población palestina, organizan bandas que agreden a las personas que desobedecen en el espacio urbano israelí la visión que ellos tienen de descanso del sábado, cuestionan las decisiones de las autoridades legítimas del estado (con rabinos dictando órdenes autorizando soldados a desobedecer a sus superiores y haciendo ceremonias para maldecir - Pulsa di Nura -políticos a favor de la retirada de los territorios y que son verdaderos incentivos para que sean asesinados) colocando muchos judíos ultraortodoxos y ortodoxos en confrontación directa con la democracia y los valores humanistas.

El fundamentalismo religioso judaico adquirió dimensiones de proyecto político, representando un esfuerzo sistemático de sectores del rabinato ortodoxo para recuperar la hegemonía en el judaísmo, perdida con la llegada de la modernidad. El Talmud, si fuera tomado el pie de la letra, es extremadamente autoritario y las puniciones son violentas. Si ellas nunca se concretaron es porque el judaísmo talmúdico nunca tuvo un estado atrás de él.

El fracaso del judaísmo secular de los pioneros y el crecimiento del poder religioso exponen hoy ante la sociedad israelí la necesidad de crear una nueva cultura judía secular. La noción de que era suficiente reunir los judíos en un lugar del cual naturalmente se destilaría una cultura judaica era una ilusión. Esta ilusión sustenta la pasividad de los israelíes seculares que pretenden que vivir en Israel asegura una vida judaica.

La cultura es un producto intencional que moviliza recursos, políticas públicas y exige del ciudadano que haga opciones. Aunque estén surgiendo importantes esfuerzos y experiencias innovadoras, todavía buena parte de los judíos seculares en Israel acepta, muchas veces de forma pasiva, las imposiciones de los ortodoxos y ultraortodoxos por una mezcla de comodidad, ignorancia e irresponsabilidad. En lugar de tener que responder preguntas como: ¿qué es una cultura judaica israelí?, ¿cuál es el papel de la religión?, ¿quién es judío y ¿qué es una educación judaica?, dejan que la ortodoxia defina los parámetros contra los cuales ellos se sublevan. Pero esta sublevación es muchas veces un juego de hacer de cuenta, donde la energía se gasta en ser contra aquello que no se desea y no en construir una respuesta propia.

El Museo de la Diáspora, localizado en Tel Aviv, temprano o tarde, deberá ser reorganizado y, en lugar de mostrar un trayecto que lleva a todas las diásporas a desembocar en Israel, deberá mostrar un camino más diversificado y abierto, por el cual la diáspora (constituida hasta por muchos israelíes que deciden dejar el país) continúa siendo una constante en la historia judaica. Al final, no es difícil demostrar que un pueblo pequeño sólo puede sobrevivir a lo largo del tiempo disociando su destino de un espacio físico único.

Aunque identificada con el destino de Israel, buena parte de los judíos del mundo permaneció en la diáspora, en un contexto de ascensión social y participación en la cultura global. El sionismo todavía lucha para reconocer este hecho. La imagen de la diáspora continúa siendo 
representada como negatividad, como el camino que lleva al abandono del judaísmo por la "asimilación".

El Estado de Israel modificó drásticamente la textura del pueblo judío, pero no lo "normalizó". Felizmente. Ni por esto es menos relevante. Dejó marcas profundas en la vida judaica contemporánea. Además de cambiar radicalmente la autoimagen de los judíos, creó una rica cultura artística y los centros académicos en Israel generaron una fructífera producción intelectual. El renacimiento del hebreo también representa una contribución importante. Aunque haya habido, durante décadas, una política sionista de suplantar el Idish por el hebreo, el Idish se esfumó en el Nuevo Mundo por causas naturales, y, en Europa Oriental, fue destruido por el Holocausto y por el stalinismo. El hebreo, sin llegar a tener en la diáspora un uso comparado al del idish o al ladino, se transformó en una fuente de identidad para los judíos de todo el mundo.

Pero, ciertamente las relaciones entre diáspora y el Estado de Israel se juegan en un nivel más profundo. Los idealizadores del Estado de Israel procuraron romper con los valores negativos que ellos asociaban a la diáspora: resignación, miedo, debilidad, sumisión. En el camino, olvidaron la principal lección de la historia judía, que las instituciones que se sustentan solamente en el poder militar son fugaces, que la fuerza de una cultura son sus valores. Si fuera solamente la contracara de la diáspora, la cultura israelí está predestinada a reproducir su lado traumático, sin los valores y el savoir-faire que aseguraron la sobrevivencia por dos mil años. Ella no será capaz de hacer la paz con los palestinos y colocará en peligro su existencia, amenazando las comunidades diaspóricas.

El futuro del judaísmo pasa por la síntesis entre valores israelíes y valores diaspóricos, entre el coraje de usar la fuerza cuando necesario y la sabiduría de que la fuerza nunca es la solución para los conflictos. El Estado de Israel ciertamente permanecerá como una referencia central del judaísmo. Pero no es la única, ni puede serla. La construcción de identidades judías en la diáspora exige un esfuerzo de afirmación de las formas locales de vivir el judaísmo. La tendencia de los gobiernos israelíes de instrumentalizar la diáspora y de los líderes comunitarios de autovalorizarse fundamentalmente por sus relaciones con el Estado de Israel perjudica al judaísmo y en nada ayudan a su renovación.
Una lección central que puede ser extraída de la experiencia del Estado de Israel es que muchas de las virtudes que eran consideradas inherentes a la sensibilidad judía (por ejemplo, la identificación con el oprimido) son producto de condiciones específicas, de la vida diaspórica. El poder político, aunque necesario, corrompe y, cuando asociado al fanatismo religioso o nacionalista, representa un enorme peligro. El judaísmo ortodoxo, en la medida en que se asocia a los proyectos políticos, ha mostrado las mismas deficiencias que cualquier integrismo religioso: es intolerante y no duda en usar la violencia para imponer su voluntad sobre el conjunto de la población. 


\section{POS-MODERNIDAD, DIÁSPORA E INDIVIDUACIÓN DEL JUDAÍSMO}

T os judíos en la modernidad siempre tuvieron dos desafíos: adaptarse a los nuevos contextos culturales en un mundo en permanente transformación y dialogar/confrontar el judaísmo de la generación anterior. Así, los judaísmos en la modernidad siempre fueron judaísmos generacionales. Esto, por un lado, lo renovó permanentemente, pero, por otro lado, dificultó la capacidad de acumulación de experiencias y de diálogo entre generaciones.

Debemos, por lo tanto, esforzarnos en comprender el contexto en que viven las nuevas generaciones, profundamente diferente de aquel en que se desarrolló el judaísmo en el siglo XX. Vivimos en una fase donde la historia, las ideologías políticas y el racionalismo, aunque no hayan sido totalmente desplazados de la vida cultural, perdieron su impulso como fuente de inspiración de valores y acción colectiva. Son tiempos de "colapso del futuro", de descreimiento de que la historia traerá una vida mejor, que la racionalidad científica posee respuestas para todas las preguntas y que la política puede satisfacer la subjetividad de los individuos. Tiempos que corroen las viejas respuestas del judaísmo del siglo XX

La globalización y la homogeneización cultural, el vaciamiento de la vida pública, el cuestionamiento de valores universales y de la razón, la individualización y la búsqueda de la felicidad personal en el lugar de utopías colectivas, son el nuevo sustrato sociocultural en el cual germina el judaísmo contemporáneo.

El mundo pos-moderno, cada vez más global y unificado por los medios de comunicación y por el consumo de masas, presenta simultáneamente un carácter de interdependencia y fragmentación en el cual todos se sienten desenraizados. Los individuos participan de múltiples subculturas "tribales" en constante mutación. Para aquellos que no consiguen convivir con la incertidumbre, con la pérdida de sentido colectivo y con la descomposición de los valores tradicionales, característicos del mundo contemporáneo, la religión aparece como un puerto seguro, en el cual se canjea la libertad por seguridad.
La condición judía en los últimos dos mil años convivió con muchos trazos de la pos-modernidad. El judío, desenraizado, tenía el mundo como referencia y la incertidumbre como parámetro. Cosmopolita, le era natural navegar entre culturas. En este sentido, judaísmo y pos-modernidad presentan elementos convergentes.

De cierta forma, la pos-modernidad "naturalizó" la condición judaica. En la modernidad los judíos eran forzados a una doble subjetividad. En público, debían hacer demostraciones extremas de integración en la cultura nacional, en tanto mantenían en la vida privada sus sentimientos de lealtad judaica. En la pos-modernidad esta bi-polaridad dejó de ser actual. Hoy, tener múltiples identidades es la norma. Las identidades crecientemente tienen referencias sub y supranacionales. Lo que antes aparecía como una anomalía, la diáspora, hoy es un fenómeno universal. Ideologías como el discurso de los derechos humanos o el ecologismo e identidades étnicas o de género, desplazaron la centralidad de la identidad nacional en las democracias contemporáneas. La exigencia de abandonar particularismos étnicos en nombre del internacionalismo no está más en el orden del día.

Si la cultura pos-moderna trajo el fin de las grandes narrativas ideológicas y cuestionó los sueños de un mundo guiado por la razón, ella también permitió una lectura menos rígida y liberadora de las relaciones entre el texto y su sentido. Al postular que toda lectura es siempre una interpretación, el sueño de Spinoza de alcanzar el significado original del texto bíblico perdió sentido, pues todas las interpretaciones son válidas, así como la contraposición entre pshat y drash, entre el sentido literal y la interpretación. Todos estamos condenados a interpretar pues nadie posee la llave del sentido original.

El joven judío del siglo XXI se distanció del judío del siglo XX, torturado por las preguntas: ¿qué es ser judío?, ¿qué es la identidad judía? que tenían como telón de fondo la exigencia de tener que elegir entre particularismo y universalismo, entre solidaridad nacional y con el propio grupo, entre tradición y utopía. No es más necesario elegir.

El judaísmo tendría así condiciones de florecer en un mundo que dejó de tratarlo como una aberración y al judío como un inadaptado. Al contrario, el cosmopolitismo, la capacidad de convivir con diversas culturas, se volvió una virtud y es objeto de cursos de especialización. El fin 
de las ideologías totalitarias, que excluían todo lo que no se ajustaba a su discurso, es sin duda saludable.

Pero la dinámica histórica es paradojal. En cuanto el mundo se diasporiza, el judaísmo se desdiasporizó. Ochenta por ciento de los judíos están localizados en dos países, Israel y Estados Unidos y ninguno de los dos es vivido como exilio.

En hebreo moderno existen dos palabras para referirse a la diáspora, Galut (exilio) y Tfutzot (diáspora). La primera posee una fuerte connotación negativa, la de una imposición externa, el destino de vivir como minoría oprimida en tierras extrañas. La segunda es neutra, se refiere al hecho de que un grupo se encuentra disperso. La experiencia de los judíos en el mundo hoy es de diáspora y no de exilio, lo que impone la construcción de nuevas narrativas de la historia judía radicalmente diferentes de aquellas que sustentaron la tradición religiosa ortodoxa, valorando la diáspora como fuente de riqueza y condición de sobrevivencia del pueblo judío.

Las nuevas narrativas deben construir una identidad judaica que no tenga como único fundamento historias de persecución y de victimización. La identidad judaica es cada vez más la expresión de una elección positiva, una identidad étnica, en lugar de una identidad estigmatizada. Ella es cada vez más libertad y menos destino.

La revalorización de identidades trasnacionales, la globalización, el éxito social de las diáspora judaicas en el mundo, actualmente al abrigo de persecuciones colectivas, re-sitúan el Estado de Israel y la diáspora en una perspectiva renovada. El sueño que orientó al sionismo, de normalización del pueblo judío, parece realizarse en el mundo pos-moderno por la vía inversa, con la condición diaspórica pasando a ser la norma y el nacionalismo un problema, pues, aunque vigente, es un marco ideológico en crisis. Sin embargo, el relativo fracaso, a la luz del siglo XXI, no fue solamente del sionismo, pero sí de todas las ideologías que renovaron el judaísmo en la modernidad, pues el mundo se judaíza y el judaísmo se normaliza por caminos que nadie previó. El mundo se judaíza porque el cosmopolitismo, la circulación internacional y la inserción intercultural son valorados, y el judaísmo se "normaliza" porque la forma diaspórica es cada vez más diseminada.
La valoración de la diáspora y de la condición diaspórica no implica contraponerla al Estado de Israel, que sería un fenómeno del pasado, como algunos intelectuales han argumentado. El estado nacional se debilitó como unidad cultural pero continúa siendo relevante. Lo que debe cambiar son las relaciones entre la diáspora y el Estado de Israel, en un sentido más igualitario y de diálogo, así como se debe reconocer que cada diáspora es diferente de la otra.

El judaísmo es una síntesis exitosa de local/global, de particular/universal. De una identidad estigmatizada, imagen que, en alguna medida, todavía está presente en Europa, se transformó en el Nuevo Mundo, ciertamente en Estados Unidos y en muchos países de América Latina, en una identidad étnica valorada y los casamientos mixtos son crecientemente percibidos por los no judíos como un paso de integración en una comunidad que es vista en forma positiva.

Las nuevas condiciones culturales son diferentes de las de los siglos pasados, orientadas por proyectos colectivos influenciados por la filosofía y el sentido de la historia. El judaísmo contemporáneo es cada vez más una construcción individual, que enfatiza lo particular y no lo universal, que se alimenta de los más variados discursos y corrientes disponibles en el mercado cultural, pero no se subordina a ninguno de ellos. Así, el judío pos-moderno recuerda las prácticas e instituciones judías de forma esporádica o en contextos particulares - nacimientos y muertes, casamientos y Bar/BatMitzvot, enfermedades, pérdida de los padres y abuelos o crisis existenciales.

En el interior del judaísmo surgen movimientos que procuran integrar las ideologías en boga - feminismo, ecología -, no tanto como una traducción del judaísmo en el lenguaje de las ideologías universales, sino como esfuerzos de actualización de la tradición. A su vez, tradiciones esotéricas y místicas, como la kabalah, fueron reembaladas como discurso de auto-ayuda y se transformó en un producto de "exportación" extremamente exitoso.

En el mundo pos-moderno, los judaísmos modernos tienden a redefinirse, particularmente aquellos que más enfatizaron la identificación de los valores judíos con los valores universales. Al final, lo que más ofrece la cultura moderna es la homogeneidad, de forma que la atracción del judaísmo hoy es su valor de particularizar y generar identidades diferenciadas "light". 
En los tiempos actuales, más aún que en la modernidad, las prácticas e instituciones asociadas al judaísmo dejaron de ser una presencia constante en la vida cotidiana de la mayoría de los judíos, que perdieron la voluntad racionalista, doctrinaria y universalista de las corrientes dominantes en el siglo XX. Así, el judaísmo pos-moderno es un judaísmo individualizado, del cual las personas se utilizan de acuerdo con estados de ánimo y circunstancias. Deja de ser el resultado de la imposición normativa de instituciones que definen estilos de vida, donde lo social prevalece sobre lo individual, para transformarse en una identidad más light, donde las instituciones proponen servicios para los individuos, que los utilizan de forma personalizada, modular, à la carte.

Este proceso no debe ser visto como algo negativo. La identidad vivida como algo monolítico es una camisa de fuerza, un bunker donde la persona se refugia por no soportar la diversidad de las experiencias culturales que el mundo contemporáneo ofrece.

Si en la modernidad el judaísmo interpelaba al individuo para que dejase de lado sus intereses personales y ayudase a mudar el mundo, en el judaísmo pos-moderno es el individuo quien interpela al judaísmo para encontrar respuestas a sus problemas subjetivos. Inclusive, las más variadas corrientes del judaísmo religioso, de los reformistas a los Luvabitch, pasaron a elaborar sus mensajes como fórmulas de auto-ayuda. El peligro obviamente es transformar el judaísmo en un soporte más de la cultura narcisista de nuestra época.

En la medida en que la identidad judaica es vivida de forma más abierta, ella permite una relación flexible con la diversidad de ofertas culturales que el judaísmo puede ofrecer. Esto lleva a expandir el mercado de consumo de bienes y servicios judaicos, en la medida en que los judíos dejan de vivir su judaísmo en grupos estancos.

Durante las últimas décadas del siglo XX- para cuya cristalización convergieron la Segunda Guerra Mundial, el Holocausto, las guerras de Israel contra los países árabes, el declive del comunismo y una fuerte tendencia a la concentración sociales medios de la población -, las comunidades judías vivieron una tendencia homogeneizadora con la marginalización de corrientes divergentes. Esa situación está llegando al fin. Pero la nueva diversidad interna en el judaísmo contemporáneo no es una repetición de lo que sucedió en el período moderno: lo que era antes una anomalía, la diáspora, pasó a ser la condición contemporánea del hombre moderno y en lugar de identificación con corrientes ideológicas, el judaísmo pasa a ser una construcción personal, individual, un bricolage en constante mutación, en el cual cada uno se apropia de productos de las diversas corrientes. 


\section{JUDAÍSMOS NACIONALES}

$\mathrm{E}$

lénfasis en la visión galútica, negativa, de la diáspora llevó a construir una narrativa del judaísmo en la cual los lugares donde floreció eran simples lugares de pasaje, espacios inhóspitos donde el judaísmo a pesar de todo conseguía sobrevivir. Una visión profundamente distorsionada de la historia judía. El judaísmo fue lo que fue, se desarrolló y se enriqueció gracias a la capacidad de convivir, interactuar, usufructuar, absorber, contribuir y elaborar las culturas locales, generando nuevas síntesis culturales. Sea en la comida, en la música, en las artes, en el conocimiento, en las formas de religiosidad y de creencias y, expresión de todo esto, en la lengua, el judaísmo siempre estuvo enraizado localmente.

¿Dónde puede ser encontrada una historia similar de amor por la tierra natal, España, como fue la continuación del uso del ladino (una versión del español antiguo) por los judíos-españoles durante cinco siglos después de la expulsión de la Península Ibérica?! O, ¿qué mejor expresión de sincretismo que el uso hasta los días de hoy por los judíos sefaradíes de un amuleto, el Hamza, en el formato de una mano con inscripciones en hebreo, cuyo origen es una leyenda ligada a la mano de Fátima, hija del profeta Mahoma?! A pesar de los judíos considerar el hebreo como la lengua sagrada, el arameo, la lengua franca de Oriente Medio por muchos siglos antes y después de la era cristiana, penetró profundamente inclusive en los ritos religiosos. Así, por ejemplo, el Kadish Iatom (la oración por la memoria de los muertos) y el Kol Nidrei (oración con la cual se inicia el día más sagrado del año - el Iom Kippur) son recitados en arameo.

Diferentes contextos locales generaron una enorme diversidad y a veces conflictividad, entre diferentes comunidades. Por ejemplo, durante la Revolución Francesa, los judíos sefaradíes procuraron distinguirse de los judíos ashkenazim, exigiendo derechos ciudadanos argumentando que ellos no compartirían el "atraso" de las comunidades de Alsacia y Lorena. Elías Canetti recuerda en sus memorias de infancia en Bulgaria que el casamiento de un sefaradí con un judío ashkenazi era un tabú. Yo mismo, en mi infancia, me acuerdo de la dificultad de comprender cómo alguien podría ser considerado judío y no hablar Ídish. La competición y el prejuicio en el interior del propio mundo sefaradí y ashkenazi era intenso $\mathrm{y}$, cuando llegaron al Nuevo Mundo, las comunidades se organizaban en función de país o región de origen (alemán, húngaro, lituano, etc.). Pero, para quien quiere descubrir la diversidad, tensiones y diferencias entre diversos judaísmos enraizados en historias locales, es suficiente visitar Israel!

La dificultad de muchos líderes comunitarios de reconocer la profunda integración entre cultura judaica y cultura local de cierta forma constituye la versión opuesta, pero igualmente maniqueísta de la versión antisemita del judío. Para este último, el judío está condenado a permanecer como un cuerpo extraño a la "esencia" de la cultura nacional. Para ciertos líderes comunitarios, el contacto con la cultura nacional puede llevar a la "asimilación".

El judaísmo sobrevivió, desde los tiempos bíblicos hasta hoy, por su capacidad de asimilar las más diversas culturas. Fue gracias a su asimilación en la cultura europea que Theodor Hetzl, un judío secular, elaboró el sionismo político y Beeer Borojov el sionismo-socialista.

¿Quién puede definir quién es un judío asimilado? Diversas corrientes del judaísmo usaron y abusaron del concepto de asimilación, básicamente como una estrategia para descalificar y demonizar otras tendencias de las cuales discordaban. Así, eran definidos como asimilados los judíos no religiosos por los religiosos, los conservadores y reformistas por los ortodoxos o los no sionistas por los sionistas, para dar algunos ejemplos. La historia nos enseña que todos estaban errados, en el sentido de que ninguna forma de judaísmo agota todas sus posibilidades y que cada innovación - como, por ejemplo, fueron en su época el jasidismo o el sionismo - representa una contribución que lo renueva y fortalece.

En la demonología construida en torno de la asimilación, ocupa un lugar de honra el judaísmo alemán. Nunca en la historia judía y quizás universal un grupo relativamente tan pequeño hizo una contribución tan importante a las artes, a las ciencias, a la cultura alemana y universal y al propio judaísmo. Pero la tragedia nazista llevó a que los judíos alemanes fuesen transformados en chivo expiatorio de aquellos que promueven una versión paranoica de la historia. Los judíos alemanes habrían sido tontos, cuando no francamente traidores, por haber creído que eran alemanes. . Que hayan sido circunstancias históricas precisas y no un destino predeterminado por el antisemitismo de una parte del pueblo alemán, llevando al poder un régimen fanático y criminal, en nada descalifica el judaísmo alemán, sin el cual ni el judaísmo ni la humanidad serían lo que son hoy. 
Si una lección podemos obtener de la experiencia del judaísmo alemán, no es que los judíos no deban vivir intensamente la cultura local, sino que no pueden engañarse sobre la naturaleza destructiva del estado moderno en manos de regímenes autoritarios. La dinámica efectiva de la sociedad moderna, en su versión capitalista o comunista, mostró que los valores de igualdad, libertad y fraternidad pueden ser rápidamente negados por fuerzas políticas capaces de movilizar sentimientos xenófobos y el terrorismo de Estado, con amplio apoyo social. El enemigo de las minorías no es la cultura local, sino los regímenes autoritarios.

La valoración de la riqueza de la experiencia judaica de integración de la cultura nacional es una forma de "normalizar" el judaísmo, tanto frente a los no judíos, pero, sobre todo, en relación a sí mismos. Lo que significa enfrentar tanto aquellos que defienden una visión de la cultura nacional como siendo homogénea, que enfatizan lo "nuestro" frente a lo "extranjero" - utilizando el nacionalismo como un instrumento de poder para excluir a todos aquellos que discrepan- promoviendo identidades étnicas xenofóbicas.

\section{JUDAÍSMO COMO RESISTENCIA, DISONANCIA COGNITIVA Y CULPA COLECTIVA}

$\mathrm{N}$ inguna de las características psíquicas que generalmente se atribuyen a los judíos es monopolio de éstos y menos aún se encuentran igualmente distribuidas. Es natural estar orgulloso de ser parte de un pueblo que generó Einstein o Freud, pero la sombra de grandes figuras no nos transforma en parte de ellas. En el mejor de los casos puede servir como incentivo a la superación individual, con la condición de que no transforme los hijos en víctimas de madres judías que esperan que cada uno de ellos reciba un día el premio Nobel...

Las características que son identificadas como siendo parte de una psicología o trazos de conducta "judía" están presentes en individuos de todas las culturas. Pero, sin poseer ningún monopolio sobre cualquier peculiaridad psicocultural, los judíos, nuevamente de forma no homogénea, poseen ciertos trazos psíquicos y savoir faire, productos de su historia, que favorecieron el éxito social que tuvieron en la modernidad. Aunque aparezcan como características individuales, inclusive en judíos que no desean asumirse como tales, ellas son producto de una experiencia colectiva.

Como mencionamos anteriormente, los judíos sobrevivieron a la Edad Media manteniendo una cultura propia y un nivel escolar mucho más alto del que predominaba en las sociedades en que se encontraban. La creencia en la futura redención mesiánica y de ser el pueblo elegido por Dios, sólidas instituciones de solidaridad y apoyo mutuo que aseguraban la cohesión y el control social y la valoración de la familia, transformaron a los judíos en un grupo e individuos con una enorme capacidad de resistencia, esto es, de soportar situaciones adversas y desarrollar estrategias creativas de sobrevivencia.

Aunque haya sido un grupo oprimido, mantuvo una autoimagen extremamente positiva de sí mismo. Freud explica esta autoimagen como un mecanismo compensatorio por las derrotas sufridas en manos de otros pueblos, desde los tiempos bíblicos. Pero, ni todo neurótico se vuelve Leonardo da Vinci y ni todo pueblo derrotado sobrevive y mantiene una autoimagen positiva. En cuanto los grupos oprimidos normalmente 
interiorizan su posición subalterna y aceptan su lugar en la jerarquía social, los judíos consiguieron mantener altos niveles de autoconfianza y se protegieron del código dominante que los humillaba. Al mismo tiempo, la lucha constante por la ascensión y por el éxito social es un síndrome de un grupo que siente profunda inseguridad sobre el futuro y su lugar en la sociedad.

Esta característica, de disposición de no aceptar las reglas de juego establecidas, de no someterse al orden social y a las jerarquías preestablecidas, es denominada de jutzpa (impertinencia, insolencia, rostro de piedra). La jutzpa fue particularmente eficaz asociada a otro trazo, producto de las condiciones de vida en la diáspora: la capacidad de soportar la disonancia cognitiva. Sabemos que la tendencia general de las personas es alinearse con el pensamiento de la mayoría. Durante siglos, los judíos fueron entrenados para vivir en dos mundos, el de la cultura dominante y el de la cultura propia. Este entrenamiento implica aprender a vivir entre dos culturas, a comprender que hay otras formas de ser diferentes de las propias $\mathrm{y}$, sobre todo, a mantener una visión del mundo alternativa a la dominante. Más aún, siendo minoritario, obliga a un esfuerzo constante de reflexión para discernir las intenciones del otro, de pensarse a sí mismo en forma diferente de la mayoría.

La capacidad de soportar la disonancia cognitiva es una de las condiciones de la creatividad. El creador es alguien que piensa diferente, que busca caminos propios, en suma, que soporta y, tanto sufre como disfruta ser un disonante cognitivo. Pensar o hacer de forma diferente, inventar salidas innovadoras, exige la disposición de seguir senderos propios, salir del sentido común - espacio en el cual el judío no podía habitar. En el contexto de la cultura talmúdica, la capacidad de soportar la disonancia cognitiva estaba fundamentalmente al servicio de la resistencia frente a la religión dominante, aunque la creatividad en relación al mundo social más amplio se haya conseguido expresar, ya al final de la Edad Media, en innovaciones en el área comercial, en la cartografía y en la navegación marítima. Ya en la modernidad, ella se expandió para todas las áreas de las ciencias, artes y sectores económicos.

El humor judaico, uno de los productos del judaísmo moderno, expresa, por el revés, la permanente necesidad de descifrar la conducta del otro para poder adecuar la propia. Es fundamentalmente una mirada crítica sobre sí mismo, focalizando sea las tragicomedias producidas por la obsesión de la madre judía con el éxito de los hijos, las relaciones con el mundo no judío o raciocinios tortuosos para obtener un resultado deseable. El humor judaico es la disonancia cognitiva aplicada sobre sí mismo, relativizando todo lo que es tomado en serio, haciendo soportable el peso de las relaciones neuróticas con el mundo. Humor exige un sentido de ironía, de distanciamiento y relativización de nuestras propias creencias y formas de ser.

En los tiempos modernos, el capital cultural, la resistencia frente a la adversidad, la jutzpa y la capacidad creativa producida por el entrenamiento en disonancia cognitiva permitieron a los judíos ocupar un porcentaje relativo muy grande de posiciones de relieve en la sociedad. Las ganancias de este éxito fueron acompañadas de costos enormes. La resistencia, la jutzpa y el éxito son características que no dejan a las personas indiferentes. Menos aún cuando ellas están asociadas a un grupo minoritario. Toda historia de éxito, colectiva e individual, lleva a proyectar en ella un ideal positivo o negativo, sentimientos de envidia destructiva o admiración, pero difícilmente genera neutralidad.

El judío, nuevamente generalizando características que difieren de individuo a individuo, posee un fuerte sentimiento de culpa colectiva. Todo grupo oprimido se siente culpable por poseer características identificadas por la cultura dominante como negativas (el color de la piel, el género, la opción sexual). Él oprimido se resiente de su destino e interioriza en mayor o menor medida las opiniones del grupo opresor. La reacción judía a este sentimiento en la modernidad ha sido la necesidad constante de querer justificar su derecho a la existencia, apelando a la contribución que los judíos dan al mundo y a un discurso ético universal del cual los judíos se consideran portadores privilegiados por el sufrimiento pasado. Ambas tendencias son comprensibles, pero el derecho a la existencia no precisa de justificación y éticas universalistas que reprimen o esconden las tradiciones particulares de sus portadores son irresponsables.

La vivencia diaspórica, en la modernidad, creó también una disonancia socio-cultural. La ascensión social de los judíos no significó el fin del estigma y los prejuicios, los judíos que ascendían socialmente continuaran sufriendo de opresión y marginalización social. Las promesas del iluminismo no parecían se concretizar en las sociedades capitalistas liberales. Un paso más era necesario. Asociada a la disonancia cognitiva, la disonancia social llevó a un porcentaje grande de judíos a identificarse con los oprimidos y humillados 
y a militar en causas políticas que reivindicaban una transformación revolucionaria. El viejo sueño mesiánico dio lugar a utopías seculares, en las cuales intelectuales judíos estuvieron desproporcionalmente representados.

A inicio del siglo XXI este escenario se modificó profundamente. Las utopías revolucionarias perdieron su impulso y las reivindicaciones de los oprimidos y humillados se fragmentaron en demandas corporativas en que cada víctima exige reconocimiento de su proprio grupo. Por su vez en la mayoría de los países los judíos consolidaran sus posiciones sociales y las situaciones en que les son negadas el reconocimiento de su dignidad huma disminuyó drásticamente. El mesianismo judío, sea en su versión religiosa o secular, que expresaba la el sufrimiento de una minoría oprimida por el poder político y la cultura dominante, perdió su papel central en el imaginario de buena parte de los judíos y en muchas de las versiones institucionalizadas del judaísmo.

\section{TERCERA PARTE:}

\section{DESAFÍOS Y FUTURO DEL JUDAÍSMO}


¿QUIÉN HABLA EN NOMBRE DE LOS JUDÍOS: ¿RABINOS? ¿Plutócratas? ¿Gobiernos DE ISRAEL?

$\mathrm{H}$ asta la modernidad, la tradición rabínica y el judaísmo prácticamente se confundían. La creación del judaísmo moderno puede ser sintetizada sociológicamente como el surgimiento de líderes que cuestionaron el monopolio de los rabinos ortodoxos de definir lo que es judaísmo. Revolución que se dio inclusive al interior del establishment religioso: rabinos liberales y después conservadores afirmaron que los rabinos ortodoxos no eran la única autoridad para definir los parámetros de la religión judaica.

A partir del siglo XIX, las nuevas elites intelectuales, en general seculares, renovaron complemente el judaísmo, transformando la ortodoxia en una corriente más, minoritaria. El movimiento de renacimiento de la lengua hebraica fue liderado por judíos seculares, que retomaron el hebraico como lengua cotidiana, en lugar de su uso restringido al estudio de textos religiosos. La literatura y, después, el teatro y el cine Idish igualmente fueron mayoritariamente obra de escritores judíos seculares. Como indicamos, el movimiento Bund, socialista idishista, era secular; así fue la mayor parte de los líderes que impulsaron el sionismo y la creación del Estado de Israel, de Pinsker a Hertzl, de Ben Gurion a Jabotinsky y de Moshe Dayan a Golda Meir.

En las últimas décadas los rabinos retomaron una posición de relieve en la vida judaica. En circuncisiones, bar mitzvot, casamientos y hasta entierros, la mayoría de los judíos piensa que es necesaria la presencia de un rabino. En la esfera pública, los rabinos ocupan cada vez más el espacio de porta-voces del judaísmo.

¿Qué sucedió? ¿Cómo fue posible este aparente retorno al pasado, aún más cuando no se sustenta en las propias estructuras tradicionales? En el judaísmo talmúdico, al contrario del papel del padre en el catolicismo, el rabino no posee ningún status especial. No existe en el judaísmo ningún intermediario en la relación entre el individuo y Dios. Ninguna ceremonia judaica exige la presencia de un rabino. Circuncisión, bar/bat mitzva, casamiento, entierro, orar en la sinagoga o cualquier otro rito prescinde del rabino. La única exigencia, en ciertas ceremonias, es el minian, o sea, la presencia de diez judíos, que simboliza la comunidad. Aunque el minian sólo pudiese ser constituido por hombres, hoy, muchas corrientes religiosas ya aceptan incluir mujeres.

En mi infancia y adolescencia, frecuenté una sinagoga ortodoxa en la cual nunca estuvo presente un rabino, así como no había rabinos en las otras sinagogas del barrio. Tampoco había rabinos en las circuncisiones, casamientos y entierros, todos ellos de judíos ortodoxos. Siempre me pareció natural un judaísmo sin la presencia de rabinos. ¿Por qué entonces hoy nos deparamos con la "catolización" del judaísmo, esto es, con una percepción generalizada de que el rabino se hace necesario para presidir una ceremonia en la sinagoga o un rito de pasaje? ¿O de que un libro sobre judaísmo debe ser escrito naturalmente por un rabino? En suma, ¿de dónde viene esta autoridad y nueva legitimidad de los rabinos?

Creo que se trata de la convergencia de varios factores, cuyos pesos son ciertamente diferentes en cada país:

1) La profesionalización del rabinato es relativamente reciente. Los grandes rabinos que elaboraron el Talmud se ganaban el pan en otras profesiones. De acuerdo con el Talmud, Hillel cortaba leña, Shammai era constructor, Joshua, herrero; Abba Hoshaiah de Turya, lavandero, Hanina y Oshaya, zapateros, Karna, un enólogo, Huna, cargaba agua, Abba ben Zemina, sastre, y así sucesivamente. El rabino no era un profesional, sino una persona que la comunidad reconocía como tal por su saber. Es sólo en la Baja Edad Media que comienza a surgir la figura del rabino, tal como la conocemos, cuya principal función era la de juzgar situaciones de litigios o de conductas a seguir en caso de duda sobre la aplicación de las reglas de la kashrut (pureza de los alimentos). Mismo así los rabinos siempre fueron elegidos por sus comunidades y podían ser despedidos a cualquier momento.

Será el judaísmo reformista, en Alemania del Siglo XIX, influido por el modelo protestante, el creador de un nuevo tipo de rabino profesional, con una formación cultural moderna, que pierde su papel de árbitro, ya que la kashrut perdió su relevancia y los conflictos civiles y comerciales pasaron a ser juzgados por el poder judicial del país. En suma, los rabinos pasaron a ser profesionales, mantenidos por comunidades cuyas relaciones con el judaísmo quedaron diluidas por la integración de los valores de la modernidad. Así, la profesionalización del rabinato expresaba el distanciamiento creciente de los judíos frente a la cultura judía y su delegación en un especialista. 
2) Lo que era un fenómeno inicialmente restringido al judaísmo reformista pasó a generalizarse entre las nuevas generaciones de judíos, especialmente las contemporáneas. En tanto las primeras generaciones de judíos seculares tuvieron una formación religiosa, contra la cual reaccionaron, pero que conocían, las nuevas generaciones no poseen mayores nociones de lo que sea la tradición judaica. Naturalmente delegan este conocimiento a especialistas, inclusive rabinos ortodoxos, aún no lo siendo ellos mismos, especialmente cuando se hacen necesarios en rituales, imitando los modelos del medio cristiano circundante.

Las transformaciones sociales del judaísmo, que llevaron a buena parte de su población a ocupar sectores de clases medias y la profesionalización del rabinato prácticamente hicieron desaparecer la figura del rabino-ejemplo-de-humanidad, que dio lugar a tantas bellas anécdotas. En ellas, algunos rabinos participaban del sufrimiento y de la pobreza en la cual vivía la mayoría de los judíos, con consejos sabios y actos de generosidad. El rabino contemporáneo es un profesional que sirve a una comunidad. Ciertamente contribuye para el mantenimiento del judaísmo y muchos de ellos hacen contribuciones importantes para su renovación. Pero no poseen ningún monopolio del judaísmo, ni son su portavoz.

Entre los rabinos y la plutocracia en el comienzo de los tiempos modernos o los asesores de la corte en la Edad Media, existía cierta división de tareas. Los rabinos eran los líderes para dentro de la comunidad y la plutocracia o los cortesanos actuaban como interlocutores con los poderes locales. Existía, y todavía hasta cierto punto subsiste, una tradición en que judíos ricos casaban sus hijas con rabinos, asegurando con la dote la sustentación de la familia. Un modelo que se repetía con cada generación, pues en cuanto el hombre estudiaba, la mujer se hacía cargo de la familia y de los negocios, lo que muchas veces llevaba, con el paso de los años, al empobrecimiento.

El judaísmo siempre fue policlasista. Solamente durante algunas décadas, al final del siglo XIX y comienzos del siglo XX, en Europa Oriental, surgió un judaísmo que enfatizaba la lucha de clases. El policlasismo del judaísmo fue fundamental para su sobrevivencia. Judíos ricos construían sinagogas, hacían filantropía, apoyaban la cultura Ídish, el movimiento sionista y la construcción del Estado de Israel, a pesar de que el movimiento sionista por largo tiempo fuese dominado por tendencias socialistas.
A medida que los valores igualitarios de los tiempos modernos fueron avanzando, el peso de la plutocracia en las comunidades pasó a herir la sensibilidad de muchos, en particular de los más jóvenes.

Obviamente existían tensiones entre ambos poderes, que se expresaban a veces cuando los rabinos juzgaban causas en que los intereses de los hombres ricos estaban presentes, aunque los mejores rabinos procurasen mantener su autonomía. Con todo, una actitud más condescendiente de los rabinos con los judíos ricos era común, llevándolos a interpretaciones más flexibles o favorables a sus intereses.

A pesar de las tensiones que el carácter policlasista de las comunidades judías pueden generar, se trata de un fenómeno enriquecedor, que en muchas circunstancias se expresa en formas de solidaridad interclasista y que sólo pueden ser aplaudidas. El problema que se presenta hoy es la tendencia de buena parte de los judíos con recursos a apoyar causas políticamente reaccionarias como la AIPAC - American Israel Public Affairs Committee -, un lobby pro-derecha en Israel en Estados Unidos, cuyas posiciones ciertamente no representan a la mayoría de los judíos americanos, o a favorecer instituciones judías ultraortodoxas, a pesar de ellos mismos no serlo. Pocos filántropos importantes, entre los cuales sobresale la Fundación Posen, invierten en el desarrollo del judaísmo secular. Nuevamente aquí se tiene el efecto de la pérdida de referencias de los judíos seculares que los lleva a la creencia de que apoyando a los judíos ortodoxos están contribuyendo para la continuidad del judaísmo.

Finalmente, los gobiernos del Estado de Israel se proclaman como representantes del pueblo judío, lo que obviamente no es el caso. Aún más porque, en muchos casos, ellos confunden los intereses políticos de sus gobiernos o del Estado de Israel con los del pueblo judío.

¿Quién representa al judaísmo? Nadie en particular. Cada institución judía tiene una legitimidad limitada, dada por el público específico que ella representa. El desafío de los judíos seculares es recuperar el papel que intelectuales y líderes seculares tuvieron en el judaísmo moderno. Ellos continúan teniendo un peso importante en Israel, particularmente escritores y científicos que son la principal voz moral de la nación. En la diáspora, la orfandad intelectual de las instituciones judías es dramatizada por el abandono de la vida comunitaria por buena parte de los intelectuales judíos, dejándolas en general en manos de personas, aunque muchas veces bien 
intencionadas, pero generalmente conservadoras y dependientes de donaciones de empresarios cuyos valores (por opción, temor o ignorancia) en general no son los de renovación del judaísmo.

\section{¿QUIÉN ES JUDÍO?: CASAMIENTOS Y ENTIERROS}

n la tradición ortodoxa, cuando un hijo o hija se casaba con un no judío, los padres debían considerarlos no como si estuviesen muertos (pues esto exigiría mantener luto), sino como si nunca hubiesen existido (sus nombres y memoria debían ser borrados o como diríamos hoy, deletados).

La definición de quién es judío es una de las herencias de la cultura talmúdica que el judaísmo moderno ha tenido mayor dificultad para enfrentar. Todo grupo tiene criterios de entrada. La matrilinealidad es un criterio posible, pero es un mal criterio que no se adapta a los tiempos actuales. Es una regla producida en el período pos-bíblico, en un cierto contexto histórico y peca por exceso y por omisión.

Por exceso, porque continúa definiendo como judío alguien que optó por salir del judaísmo, inclusive convirtiéndose a otra religión. Esta imposición de identidad se justificaba en los tiempos en que los judíos eran forzados a convertirse. Pero no en los tiempos actuales. Cuando le es negado por Yad Vashem (el museo del Holocausto en Jerusalén) el título de "Gentil Justo" a Nicholas George Winton, que salvó del Holocausto 669 niños judíos, porque sería judío, a pesar de que sus padres, nacidos judíos, se hayan convertido al cristianismo y él mismo haber sido criado dentro de esta tradición, está siendo realizada una enorme violencia simbólica.

Por omisión, porque excluye todos aquellos - generalmente hijos de casamientos en que el padre es judío - que desean ser judíos pero no desean someterse a un rito de pasaje definido en términos religiosos.

No tiene legitimidad histórica, pues, de acuerdo con el principio de la matrilinealidad, no habría judíos, pues Abraham, Isaac y Jacob, Moisés, David y Salomón, tuvieron esposas no judías y la Biblia no habla de conversiones. El rey David desciende de Ruth, la moabita. La condición de sacerdote (cohen y levi) es transferida hasta hoy por línea patrilineal. En el relato bíblico cuando los hermanos de Moisés, Aron y Miriam, lo critican por haberse casado con una no judía (Kushit, posiblemente de origen africana), Dios castiga a Miriam con lepra. Cuando la Biblia expresa una preocupación con los casamientos mixtos, ella se encuentra en libros tardíos (Levítico y Deuteronomio) y la preocupación instrumental es explícita: que 
los judíos terminasen diluyéndose entre los otros pueblos, por la introducción de cultos idolátricos.

Aunque el Talmud reconozca una amplia categoría de formas de periferia judaica (diferentes tipos de guerim - personas que viven en el entorno judaico siguiendo los valores básicos del judaísmo), predominó en la tradición talmúdica la matrilinealidad y la oposición ydn-goym, asociada al par puro/impuro. Una versión que explica la adopción de la matrilinealidad es que solamente la maternidad y no la paternidad, en la época, podía ser asegurada. Otra explicación es que se trató de una forma de proteger los niños nacidos de violaciones por fuerzas conquistadoras, en particular en el período romano.

Aún así, en la práctica, la patrilinealidad continuó presente en la diáspora. Investigaciones genéticas recientes indican que gran número de comunidades judías tiene origen patrilineal, producto de casamientos entre judíos y mujeres locales. En suma, la matrilinealidad no se sustenta en principios teológicos o históricos, es una convención que predominó en cierto período de la historia judía.

Esta tradición, en la modernidad, comenzó a cambiar, inicialmente con una mayor tolerancia frente a los casamientos mixtos de ricos y famosos. Nadie osa criticar los Rotschilds por casarse con no judías, ni Albert Einstein y buena parte de los Premios Nobel y artistas famosos, de quien los judíos se enorgullecen. Einstein, inclusive, fue invitado a ser el segundo presidente de Israel, lo que habría llevado a una primera dama no judía. La música de Januka más popular en Estados Unidos, Crazy for Chanukah, de Adam Sandler, festeja que "Paul Newman's half jewish, Goldie Hawn's half too. Put them together, what a fine lookin jew" "Harrison Ford's a quarter Jewish - not too shabby!"

La norma matrilineal no es más actual. El judaísmo no vive rodeado de pueblos paganos, ni las mujeres judías son violadas o la paternidad no verificable. El peligro real hoy es el inverso, que los hijos de los matrimonios mixtos sean alejados por los prejuicios de las comunidades judías.

La mayoría de los judíos percibe la humanidad como una sola, donde las personas buscan prioritariamente su propio bienestar y felicidad y para quienes las diferencias no deben ser un obstáculo a la convivencia amorosa. Naturalmente, la interacción social lleva cada vez más a casamientos mixtos. Prácticamente la mitad de los judíos de la diáspora se casa con no judíos y los padres se encuentran divididos entre mantenerse apegados al pasado y aceptar nuevas reglas que no excluyan sus hijos del judaísmo. Ciertamente muy pocos de ellos están dispuesto a deletarlos.

Las instituciones tradicionales que definen quién es judío están, lentamente, readaptándose a los nuevos tiempos. En Israel existe un movimiento para retirar el monopolio de los rabinos sobre las conversiones por la creación de un rito de "judaización secular", que permitiría la integración al judaísmo de aquellos que no se consideran religiosos. La continuación en Israel del monopolio religioso ortodoxo de la definición de quién es judío lleva inclusive a una paradoja: siendo que la tradición judaica ortodoxa es matrilineal y la musulmana es patrilineal, el hijo de un musulmán y de una judía estaría condenado por la ley israelí (que reconoce igualmente el poder del clero islámico) a pertenecer simultáneamente a las dos religiones.

Aunque los intereses demográfico-estratégicos del Estado de Israel lo lleven a una flexibilidad enorme en torno de los orígenes judíos de un candidato a la emigración, la política interna entregó al rabinato ortodoxo el monopolio sobre la definición de quién es judío, así como sobre los matrimonios y conversiones. Una situación que se repite periódicamente en Israel: un joven soldado, generalmente venido de la ex-Unión Soviética (y centenas de millares de emigrantes son judíos por origen patrilineal) muere en el frente de batalla. Cuando va ser enterrado, el rabino declara que no es judío, pues su madre no se convirtió al judaísmo. Por lo tanto le es prohibido el entierro en el interior del cementerio militar o cualquier otro cementerio controlado por el rabinato. En algunos casos, el cuerpo llega a ser "repatriado" para el país de origen de él o de los padres, y en otros casos es enterrado en un cementerio "privado", generalmente un kibutz que mantiene cementerios fuera de la jurisdicción del rabinato.

En ciertos países en la diáspora existe una diversidad de cementerios judíos o en ciertos casos, administrados en condominio por diferentes corrientes. Pero, en muchos países, la comunidad delega las decisiones totalmente a los rabinos ortodoxos. Cuando recientemente un famoso humorista brasileño, Bussunda, falleció y fue enterrado en el cementerio Son João Batista, un líder comunitario refiriéndose al hecho afirmó que él ejemplificaba un "holocausto silencioso". Sin entrar en la referencia ignorante y ofensiva de la comparación con el Holocausto (como si el 
asesinato bárbaro y la elección personal puedan tener algo en común), lo curioso es la ceguera de los propios líderes en relación a su responsabilidad directa en expulsar los judíos de su seno. Pues al final, si la voluntad de Bussunda fuese la de ser enterrado al lado de su esposa, el entierro sólo podría haber sido en un cementerio no judío.

La corriente humanista secular, el judaísmo Reformista, parte del movimiento Reconstruccionista y ciertos rabinos del movimiento Renewal, aceptan como judíos hijos de madre o padre judío, en la medida en que el niño fue educado dentro del judaísmo, cumplió los ritos de pasaje (circuncisión, bar/bat mitzva) y se define como judío. Por el contrario, a los judíos que se convirtieron a otra religión, les es exigida la conversión si quisieren retornar al judaísmo. El movimiento conservador, aunque dividido, mantiene el principio matrilineal.

La presión del judaísmo estadounidense obligó a que conversiones realizadas por rabinos conservadores y reformistas en la diáspora sean aceptadas como legítimas por el rabinato israelí, pero las conversiones realizadas por estas corrientes en Israel no son reconocidas. También, muchos rabinos ultraortodoxos no aceptan conversiones realizadas por rabinos ortodoxos. En Israel, recientemente, la nueva dirección más rigida de la institución rabínica a través de la cual el estado delega la definición de quién es judío canceló muchas de las conversiones realizadas por el liderazgo anterior, ultraordoxo.

Así las conversiones realizadas por rabinos conservadores son cuestionadas por los ortodoxos y más aún por los ultraortodoxos. Pero, igualmente, muchas de las conversiones realizadas por los ortodoxos son cuestionadas por los ultraortodoxos, y entre los propios ortodoxos existen divisiones sobre el tema. Estas divisiones son extremamente positivas, pues indican que definitivamente el judaísmo hoy es plural y que las comunidades deben aceptar este hecho.

\section{ANTISEMITISMO Y LAS RELACIONES YDN Y GOYM}

Creadores del esperanto, proyecto cosmopolita que deseaba sustituir las lenguas nacionales, con un porcentaje relativamente alto en relación al conjunto de la población de militantes comunistas y empresarios capitalistas, los judíos fueron transformados con facilidad en un chivo expiatorio por todos aquellos que procuran un culpable externo para los males de las sociedades modernas, en particular en situaciones de crisis económica. Los judíos son entonces transformados en un poder invisible, organizadores de conspiraciones que explicarían el orden mundial y las transformaciones que generan incertidumbre y miedo frente al futuro.

La orientación para la innovación y el éxito social de los judíos produjo sentimientos contradictorios, reacciones de admiración y/o odio que se nutren de las contradicciones inherentes a los valores de la modernidad, al mismo tiempo que dan continuidad y/o actualizan viejos prejuicios asociados a la Iglesia Cristiana y al Islam. El judío sobresale en un mundo con valores igualitarios, es fuertemente solidario en sociedades individualistas, es innovador y abierto a lo nuevo, pero consigue de alguna forma mantener sus tradiciones. Los judíos no se encuadran en las categorías de nación, clase social, corporación o etnia, que utilizamos para comprender los agrupamientos en las sociedades modernas.

En personas, ideologías y culturas orientadas para el futuro, el judío es valorado y en aquellos que romantizan el pasado, el judío tiende a ser representado como destruidor de un mundo idealizado. La asociación de los judíos e Israel con Estados Unidos produjo una alianza esdrújula entre fundamentalistas islámicos y grupos de militantes antiglobalización.

Siglos de percusiones transformaron el antisemitismo en la clave de interpretación que los $Y d n$ ( $Y d n$ es la auto-denominación, en el plural, de los judíos en Ídish) usaron para comprender su relación con los Goym (no judío, así denominados en el Talmud, aunque en la versión bíblica goym se refiera genéricamente a todos los pueblos, inclusive el judío). Esta tendencia es comprensible, si bien que criticable cuando produce conductas xenofóbica en un grupo que experimentó por siglos la humillación, persecución y el trauma enorme del Holocausto. 
El sentimiento profundo de fragilidad de la condición judía es difícil de trasmitir en el mundo contemporáneo, donde tantas personas y pueblos pasan necesidad, sufrimiento y opresión. Pues si los judíos fueron víctimas por largos siglos, hace décadas que viven en general en una situación de prosperidad, aunque existan mucho más judíos pobres que lo que el imaginario popular reconoce.

Muchos no judíos no entienden por qué los judíos se auto-representan como víctimas cuando fueron tan exitosos socialmente, mientras para los judíos la inexistencia de persecuciones en la mayoría de los países donde viven no elimina el miedo de que el antisemitismo pueda resurgir.

El miedo no es irracional, aunque ciertas expresiones de él puedan serlo. En tanto las sociedades no se asuman como responsables por sus problemas, en lugar de transferir la "culpa" a terceros, el antisemitismo continuará siendo un peligro potencial. En particular, la experiencia histórica muestra que, en situaciones de crises económicas o políticas, algunos líderes buscan un chivo expiatorio a quien responsabilizar por el malestar social. Los judíos cumplieron este papel en el siglo XIX y en la primera mitad del XX. En la actualidad, en la mayoría de los países musulmanes, el antisemitismo, junto con el antiamericanismo, cumple el papel de chivo expiatorio de las dificultades culturales de adaptación al mundo moderno.

Situación hasta cierto punto similar se da en relación a los israelíes. Les cuesta entender la simpatía de buena parte de la opinión pública internacional con los palestinos, que viven en su mayoría en condiciones de pobreza y opresión, mientras ellos usufructúan un alto nivel de vida y son una mini-potencia militar. Pero, la percepción de los israelíes no es simple autoengaño. Es alimentada por críticos de la política externa de Israel que tienen una condescendencia irresponsable con los grupos que proponen su destrucción, confundiendo el objetivo, legítimo, de la causa palestina de creación de un estado propio, con las ideologías y los líderes a ella asociados, muchos de los cuales tienen una agenda política potencialmente genocida.

La dificultad de comunicar la fragilidad de la condición judía y el peligro del antisemitismo ha llevado a la mayoría de los líderes comunitarios a denunciar en forma a veces histérica cualquier expresión que pueda tener una connotación negativa del judío o de las políticas del Estado de Israel. Sin duda, existen claros actos antisemitas, que deben ser denunciados y combatidos, pero en nada ayuda denominar cualquier comentario de crítica a la política de los gobiernos israelíes como antisemita. Igualmente no contribuye llamar cualquier acto pre-conceptuoso como antisemita en el sentido de estar cargado de odio y promover la negación de la humanidad de los judíos. Sé que se trata de un argumento que puede ser usado por antisemitas/racistas/sexistas. Cada caso debe ser ponderado, pero la hipersensibilidad del oprimido no justifica la confusión de cualquier expresión políticamente incorrecta con odio racial.

Aclaremos que no estamos justificando expresiones indebidas. Ellas deben ser combatidas, pero con la ponderación debida en cada caso. Porque infelizmente el racismo, sexismo, etc. pueden producir una industria de victimización, de líderes e instituciones que se proyectan por la denuncia, llevándolos a presentar una versión distorsionada o inflada de los hechos.

Un comentario mal elaborado en torno a raza, religión, sexo o etnia no transforma alguien en racista, antisemita, homofóbico o sexista. El concepto de racismo esconde una diversidad de situaciones. Un comentario prejuicioso no significa que el individuo esté dispuesto a entrar en el $\mathrm{Ku}$ Klux Klan o en el partido nazista o que esté imbuido de odio racial. La mayoría de las personas que hacen estos comentarios se disculpa cuando se concientiza que hirió la sensibilidad de alguien.

Todos los pueblos y grupos poseen prejuicios, estereotipos negativos, chistes, sobre otros grupos y sus vecinos. Sin duda los grupos que asocian estos prejuicios a historias de opresión son más sensibles a ellos. Pero eso no debe obliterar la comprensión de que se trata de un fenómeno generalizado, producido por la tendencia natural de cada cultura a verse a sí misma como poseyendo cualidades mejores que las otras, que exige sobretodo una actitud pedagógica.

El respeto por la sensibilidad ajena y más aún en el espacio público, sea en relación a objetos sagrados o a grupos que sufrieron discriminación, humillación y persecución, es fundamental para construir una sociedad donde nadie sienta negada su dignidad humana. Este objetivo, sin embargo, es un ideal en dirección al cual procuramos caminar, pero que es construido a partir de un bagaje cultural, donde hábitos lingüísticos, formas de humor y prejuicios inconscientes están presentes. Como señalaba Sartre, las personas no se dividen en racistas y anti-racistas, sino entre los que los que se acomodan y los que enfrentan el racismo que cada uno lleva dentro de sí. 
La tendencia excesiva a gritar "fuego" es típica de muchas instituciones y líderes comunitarios que tienen en el antisemitismo su razón de ser y el único tema a comunicar. Sin duda existen fuegos e incendios y sobre ellos debe ser concentrado el combate, y, en el resto, actuar pedagógicamente, no denunciativamente.

No podemos olvidar que comentarios con alguna connotación negativa sobre los goym son algo relativamente común en una conversación dentro de un grupo de judíos. ¿Esto implica odio, negación de la humanidad del otro, voluntad destructiva? Ciertamente no. Lo que no elimina el hecho que la realidad histórica del antisemitismo permitió al judaísmo institucionalizado, inclusive a los intelectuales judíos, obliterar y no enfrentar las dimensiones problemáticas que muchos judíos presentan en sus relaciones con los no judíos (goym).

Esto lleva a la necesidad de enfrentar el anti-goysmo o goy-fobia que, en mayor o menor proporción, existe entre los judíos y que fue generado y reforzado por la larga historia de persecución. El argumento de que el antijudaísmo llevó a masacres y el anti-goysmo es inocuo es, desde ángulo en que estoy discutiendo el asunto, irrelevante. Para transformar el mundo el humanismo debe ser cultivado transformando tanto los grupos dominantes como por los dominados.

Seamos claros, no se trata de explicar el antisemitismo por las características judías, pues el odio se alimenta de sí mismo y no de las características del otro. No se trata tampoco de desconocer la importancia de luchar contra el antisemitismo. Pero lo que está también en juego es identificar características que deben ser mudadas no para agradar al otro, sino para actuar sobre aspectos que limitan la capacidad del judaísmo de avanzar en el proceso de integrar valores humanistas y humanizar la condición judía. Inclusive superando la tendencia a verse en demasía a través de la mirada de los no judíos.

El judaísmo del siglo XXI deberá realizar un esfuerzo de autoanálisis y auto-transformación de sus relaciones con los goym. Los mandamientos de la Biblia, radicalizados por la interpretación talmúdica, tenían como una de sus funciones separar judíos de no judíos. Esta separación, como en todas las culturas pre-modernas, estaba asociada a una valoración de la propia cultura y a la desvalorización de la extranjera (cristianos y paganos, fieles e infieles, romanos y bárbaros) y que continuó en la modernidad, muchas veces al servicio de ideologías colonialistas y racistas, contaminando inclusive grupos oprimidos.

El judaísmo rabínico tradicional terminó cerrando el mundo judío sobre sí mismo y sus valores referidos fundamentalmente al mundo judío y en general predominaron las interpretaciones que separan y oponen judíos y no-judíos (en el judaísmo ultraortodoxo, por ejemplo, el descanso sabático sólo puede ser quebrado para salvar una vida judía, no la de un goy).

La Biblia cuenta que Dios creó la humanidad, no a los judíos, a su imagen. En ella aparece permanentemente el mandamiento de respeto por el "extranjero que vive en tu tierra", inclusive que sea amado como a sí mismo. En el Talmud convive una actitud excluyente con momentos de apertura al mundo no judío. Así, por ejemplo, el Talmud identifica siete mandamientos Nohaicos, que habrían sido entregados a Noé después del diluvio (y que no aparecen en la Biblia): prohibición de la idolatría, asesinato, robo, promiscuidad, blasfemia, comer carne de animal aún vivo, seguir leyes justas. Estos mandamientos serían aplicables a todos los pueblos y sus seguidores serían goym justos y con derecho a participar del mundo por venir. Como mencionamos anteriormente, los moradores de Israel que seguían las leyes Nohaicas eran vistos como parte de la comunidad y, sus hijos, como judíos potenciales. Esta apertura del Talmud fue en gran medida abandonada, inclusive por las prohibiciones de proselitismo impuestas por el islamismo y el cristianismo.

La contraposición con los goym fundada en la tradición religiosa asumió formas dramáticas por los siglos de percusiones y llevó, hasta tiempos recientes, a un sentimiento básico de que todo goy era un antisemita potencial. La relación del judío con el goy incluía, y a veces todavía incluye, una mezcla de miedo, desconfianza, resentimiento. En ciertos contextos culturales ellos incluían un desprecio por las formas de vida no judía, fortalecidos por el hecho de que, hasta tiempos recientes, la mayoría de los judíos en Europa Oriental y en el mundo musulmán se relacionaba fundamentalmente con goym de los sectores populares, brutalizados por las condiciones de penuria y bajos niveles de educación, que reforzaban los prejuicios. A medida que los judíos fueron ascendiendo socialmente y conviviendo con otros sectores sociales de nivel cultural similar, este sentimiento se fue desvaneciendo. 
Las relaciones prejuiciosas que a veces los judíos tienen con los goym son un tema tabú en la educación judaica. No debería ser así. Proyectar, usando hechos de la historia pasada, una visión deshumana del goy deshumaniza y debilita al judío. Cuando confrontado a situaciones de prejuicio, en lugar de establecer un diálogo, se cierra automáticamente en la posición de víctima. Si entendemos nuestros propios prejuicios, seremos más capaces de dialogar y educar a los otros para cambiar sus actitudes. Parafraseando Sartre, no se trata de discutir si existe o no una tendencia a desvalorizar al o goy, sino de luchar contra esta tendencia, arraigada en dos mil años de historia.

\section{EL FUTURO DEL JUDAÍSMO}

T a segunda mitad del siglo Xx fue extremamente favorable para los judíos y para el judaísmo. El antisemitismo, como política de estado desapareció de las sociedades donde viven la mayoría de los judíos. En general ellos se concentran en las clases medias y ocupan posiciones de realce en las diversas esferas sociales. Infelizmente, el pasado no puede ser proyectado linealmente. Si alguna certeza podemos tener sobre el futuro, además de que es imprevisible, es que nunca es pura repetición del pasado o simple continuación del presente.

El contexto que permitió el éxito (y los dramas) de los judíos y del judaísmo en los tiempos modernos está cambiando rápidamente. ¿Qué contexto fue este? La concentración de la mayor parte de los judíos primero en Europa y después en Estados Unidos, regiones que comandaron la revolución económica, política, cultural y tecnológica del mundo moderno. La llamada contribución judía al desarrollo de la cultura moderna está directamente asociada a las posibilidades que las sociedades modernas abrieron para los judíos.

En el siglo XXI, el eje del poder económico y militar, lenta, pero inexorablemente está transfiriéndose para Asia. Tanto Europa como Estados Unidos están perdiendo su peso relativo en el sistema económico mundial.

Como indicamos, más de $80 \%$ de los judíos del mundo viven en Estados Unidos y en Israel. El resto se localiza mayoritariamente en Europa. Esto coloca varios desafíos al futuro de los judíos y del judaísmo. La relativa decadencia de Estados Unidos y de Europa y la transferencia paulatina del eje dinámico de la economía mundial a Asia implicará que los judíos se encontrarán cada vez más en la periferia del sistema internacional.

El nuevo contexto internacional podrá generar nuevos conflictos de poder revestidos de guerras culturales. La relativa marginalización de Occidente afectará la dinámica cultural y política de los actuales países avanzados. Ciertamente este proceso redefinirá la visión de Occidente sobre sí mismo, así como el lugar de los judíos dentro de ella. 
Las consecuencias de este cambio sobre el Estado de Israel serán dramáticas. La alianza estratégica con Estados Unidos, que aseguró en las últimas décadas su seguridad, posee piernas cortas: el tiempo de permanencia de Estados Unidos como potencia hegemónica. El futuro de Israel depende de la paz e integración en Oriente Medio.

El tema central que se presenta para el judaísmo no es si el mundo cambiará, sino cómo enfrentar estos cambios. La visión estrecha, que supone que las únicas alternativas para permanecer judío serían vivir en Israel o ser un judío ortodoxo en la diáspora, todavía es dominante en muchas instituciones comunitarias. Ella podrá transformarse en una profecía que se auto-realiza, en la medida en que el diagnóstico afecta las conductas y se transforma en realidad. Si, por el contrario, el judaísmo apuesta en una visión pluralista, sus chances de sobrevivencia serán mucho mayores. La idea de que los judíos pueden sustituir su pequeño número con calidad es ilusoria. La demografía cuenta.

Para algunos judíos seculares, los ultraortodoxos producen rechazo, para otros, el sentimiento de que ellos son la más auténtica expresión del judaísmo. La primera reacción es justificable en la medida en que la ultraortodoxia y ciertos grupos ortodoxos vehiculan valores que hieren la conciencia moral de una persona moderna, y la segunda, igualmente comprensible, pues muchos judíos se sienten inseguros sobre la propia capacidad de mantener el judaísmo. Pero ambos están equivocados, pues, en el primero caso, se desconsidera la contribución específica que ellos tienen para el judaísmo y, en el segundo, porque considera que en el pasado se encuentran todas las respuestas para el tiempo presente.

El actual auge relativo de la ortodoxia refleja sin duda factores sociológicos. La búsqueda de raíces por parte de una generación que perdió cualquier referencia existencial más profunda con la tradición judaica hace parecer auténtico aquello que tiene una apariencia externa de "diferente". El desconocimiento de la propia tradición, en la sociedad del espectáculo en que vivimos, lleva a suponer que un judío vestido con ropa exótica calcada en los modelos de Europa Oriental del siglo XIX y hablando una lengua derivada del alemán, el idish, sea representante de un judaísmo más auténtico.

La interpenetración cultural de la sociedad contemporánea produjo un miedo profundo de disolución de fronteras. Para muchos judíos seculares, la expansión de las formas de vivir el judaísmo hacia estilos distantes de su propia memoria los lleva a sinagogas ortodoxas, a pesar de que ellas no expresan sus valores. Algunos sectores de judíos seculares preocupados con el futuro del judaísmo consideran que la ortodoxia es una garantía de continuidad del judaísmo, a pesar de discordar de ella. Puro engaño. Puede ser que el judaísmo ortodoxo presente mecanismos seguros de reproducción. Pero será la reproducción de una secta. No del judaísmo como una tradición viva en diálogo con la historia.

El judaísmo excluyente continuará existiendo en Israel y en la diáspora, pero la mayoría de los judíos no desiste de una identidad judaica que sea inclusiva de los valores de la modernidad. El judaísmo se individualizó y esta individualización afecta al propio judaísmo ortodoxo y ultraortodoxo. Muchos de los que sienten afinidad con la ortodoxia desarrollan su versión personal de judaísmo, cumpliendo ciertos mandamientos y no otros.

Un nuevo judaísmo inclusivo y sin miedo del proselitismo representa la única alternativa para la sobrevivencia del judaísmo. Una de las tragedias de la herencia de las persecuciones medievales fue la que transformó la necesidad en virtud, llevando a interiorizar la prohibición de la Iglesia Católica y del Islam de hacer proselitismo en algo positivo. El gueto físico creó una mentalidad de gueto. Pero esto está cambiando. La valoración de la Kábala como producto que atrae un amplio público no judío de consumidores de productos esotéricos es un ejemplo de la creación de nuevos espacios culturales y de una periferia no judía que se aproxima al judaísmo. Esta tendencia a la apertura encuentra todavía grados variados de oposición dentro de las instituciones judías dominantes, pero terminará imponiéndose. Y abre nuevas posibilidades y desafíos al judaísmo secular. 


\section{EL FUTURO DEL JUDAÍSMO SECULAR}

$\mathrm{L}^{\mathrm{a}}$

gran mayoría de los judíos es secular y humanista, en el sentido que son judíos que se definen como tales en función de lazos humanos y valores de solidaridad, sin referencia a creencias religiosas. En el mundo contemporáneo, lo que define al judaísmo de los judíos seculares no es una ideología precisa, sino son sentimientos, y sentimientos por su propia naturaleza son inestables. Mientras el judaísmo moderno, aunque dividido, mantenía en el interior de cada corriente una gran capacidad de acción colectiva, en la sociedad contemporánea, el carácter difuso, ad hoc, de la vida judaica secular limita las posibilidades de cristalización de orientaciones colectivas.

Esto hace con que los judíos seculares, aunque mayoritarios en Israel y en la diáspora, sean particularmente frágiles en relación a la institucionalización de su judaísmo y una voz poco expresiva en las instituciones comunitarias. Paradojalmente, muchas veces son judíos seculares los que se encuentran al frente de las instituciones judías, pero no asumen posiciones seculares.

En general, la intelectualidad judía secular se encuentra alejada de la vida activa de las instituciones judías, que aparecen como conservadoras, cuando no reaccionarias. Buena parte de las instituciones comunitarias no está interesada en dar voz a los judíos seculares, aunque recuerda permanentemente el número de intelectuales judíos famosos, mayoritariamente seculares.

Las ideologías que en el siglo XX permitían dar expresión a los sentimientos del judío secular entraron en crisis. Los dos pilares sobre los cuales se construyó el judaísmo secular no religioso fueron el socialismo y el sionismo, promoviendo, ambos, una visión renovada de la historia judía, dando continuidad a los valores de solidaridad y justicia social. No es preciso comentar la crisis del socialismo, y, en lo que se refiere al sionismo, él realizó su sueño y perdió la fuerza movilizadora que tuvo antes de la creación del estado y en sus primeras décadas.

En el siglo XX, los judíos seculares estuvieron íntimamente vinculados a una visión histórica del pueblo judío y a la elaboración del mesianismo como utopía terrena. Ambos pilares están en crisis. Vivimos en un período de descrédito de la idea del progreso y de temor e incertidumbre sobre los vientos de la historia y donde el mesianismo secular entró en crisis, con la desintegración de las grandes ideologías políticas Hoy, las nuevas generaciones no encuentran un sentido particular, sea en la historia en general o en la historia judía en particular. En lugar de Historia con mayúscula, cada uno se refugia en la subjetividad y procura construir su propia narrativa personal. Pero la búsqueda narcisista de la felicidad individual sin preocupación con la colectividad es una quimera. La destrucción de los lazos sociales produce un infierno colectivo.

El judaísmo secular del siglo XX fue un ejercicio de sustituir lo sagrado, representado por la creencia en la fusión del pueblo judío con Dios, por la santificación del pueblo en la forma de un proyecto político de nación o de ética social universal. En la perspectiva de este comienzo de siglo XXI, ambos proyectos se mostraron un éxito y un fracaso. Fueron un éxito histórico porque tuvieron un impacto definitivo en la sociedad contemporánea, sea creando el Estado de Israel, sea contribuyendo para consolidar valores de justicia social como parte del programa de las sociedades democráticas. Pero fracasaron en la medida en que las transformaciones culturales y sociales iluminaron sus debilidades: la no valoración del individuo, tanto en sus dramas subjetivos, como en la necesidad de mantener y renovar los vínculos con el pasado.

En suma, el trípode de la modernidad, razón, historia y política, que motivó a generaciones a enfrentar y transformar la tradición talmúdica entró en crisis. En algunos casos el vacío existencial llevó a algunos a procurar en la ultraortodoxia respuestas y certezas para un mundo que parece desprovisto de sentido. Pero la gran mayoría de los judíos no dejó de creer y apostar en los grandes valores de la modernidad, en la posibilidad de que la humanidad camine en dirección a una mayor integración y convivencia pacífica. Pero se encuentra huérfano de proyectos colectivos.

Las diversas corrientes seculares proponían una fusión entre individuo y colectivo que hoy no es más actual. En el mundo contemporáneo, en lugar de fusión tenemos puentes, eslabones frágiles que sirven de apoyo al individuo para encontrar un sentido en el mundo. Porque, si el individuo es el sujeto sobre el cual se construye la sociabilidad contemporánea, sólo se 
sustenta gracias a la identificación con valores colectivos, sin por esto abdicar de la libertad y de la capacidad de reflexión crítica.

El individualismo exacerbado genera la ilusión de que el individuo es autosuficiente. Nunca lo es. Precisa de objetos de afecto, apoyo y transcendencia. El judaísmo humanista tiene todas las condiciones para ser uno de estos soportes, ofreciendo formas de identificación no opresivas con la tradición y la comunidad. Puede ser un instrumento de relacionamiento con el pasado, inclusive con la memoria de los padres y abuelos, sin que este pasado domine el presente. Puede crear vínculos con la tradición, permaneciendo abierto a los aires del mundo y mantener lazos particulares de solidaridad, sin perder la sensibilidad frente al sufrimiento de todos los seres humanos.

El nuevo judaísmo secular, sin olvidar las dimensiones colectivas, deberá ser también capaz de hablar al individuo, a sus dramas subjetivos y existenciales, conteniendo elementos de auto-ayuda y de celebración de la propia identidad, sin caer en un etnocentrismo alterofóbico o autocomplacencia narcisista.

La memoria es fundamental para nuestro sentido de identidad. Pero no puede ser opresiva. Nuestra memoria debe estar de acuerdo con la identidad que queremos construir. Toda memoria colectiva es siempre una construcción al servicio de una identidad. Cuando aceptamos cierta versión de la memoria colectiva, estamos aceptando simultáneamente la identidad que ella enmarca. No es que podamos construir versiones aleatorias de nuestro pasado. De alguna forma ellas se alimentarán de las versiones anteriores. Pero la memoria colectiva es siempre maleable e innovadora, como indica el pasaje del mundo bíblico al talmúdico y posteriormente a las formas modernas de judaísmo.

La mayoría de los judíos seculares son hoy individuos aislados, llenos de dudas, lo que genera sentimientos inestables sobre el sentido de ser judío. Por más que el judío secular valore su individualidad y derecho a tener su versión de judaísmo, su crecimiento y fortalecimiento exigen formas colectivas de expresión.

¿Qué puede funcionar como un aglutinador y estabilizador de la identidad judaica secular? Nuevas narrativas y, en particular, prácticas que permitan insertar la subjetividad personal en un judaísmo que tenga como referencia una cultura acumulada en tres milenios, sin reproducir los contenidos xenofóbicos y alienantes de las categorías de pureza y impureza, de pueblo escogido, de protección divina.

El judaísmo secular es generalmente agnóstico o ateo, enraizado en la cultura racionalista, humanista y científica de nuestro tiempo. Se trata de un excelente antídoto contra el irracionalismo, el dogmatismo y el autoritarismo. Pero debemos reconocer que el racionalismo tiene capacidad limitada de satisfacer las necesidades emocionales que relacionan a las personas y grupos. La búsqueda de sentido y la creación de lazos sociales incluyen dimensiones que se encuentran fuera de la esfera de la racionalidad, pues involucran ritos, ceremonias y espacios de convivencia donde las personas puedan compartir sentimientos colectivos.

Ya hace casi un siglo que el gran filosofo Martin Buber llamó la atención sobre la diferencia entre religión y religiosidad. Mientras la primera se refiere a las dimensiones institucionalizadas de la vida religiosa, la segunda expresa la búsqueda personal por transcendencia. Para Martin Buber, la religión puede estar desprovista de religiosidad, así como la religiosidad no precisa de instituciones religiosas para expresarse -no es casual que Buber no fuese un asiduo frecuentador de sinagoga. Sentimiento similar fue expresado por Albert Einstein: "es precisamente entre los heréticos de cada época que encontramos personas que están imbuidas con este tipo de más alto sentido de sentimiento religioso y que muchas veces son vistos por los sus contemporáneos como ateos y a veces también como santos".

Esta distinción es fundamental, pues funda la posibilidad de una visión humanista de la religión, que ya estaba presente en las grandes tradiciones místicas: la experiencia espiritual es un camino personal que no puede ser confundida con ritos ni transferida a un poder externo o instituciones formales. La búsqueda de un sentido transcendental o espiritual de la vida es siempre un camino construido personalmente, que no puede ser transformado en verdades que pueden ser impuestas a los otros. El misterio de la vida deja de ser un misterio cuando es encuadrado en las respuestas dadas por cada religión.

Lo sagrado, inclusive en sociedades individualizadas y democráticas, no dejó de existir. ¿Qué sagrado es ese? Es aquello por el cual si fuese preciso se está dispuesto a luchar con riesgo de morir, pues sin él la vida no tiene sentido. $\mathrm{O}$, visto de forma positiva, es aquello que nos da fuerza vital y el sentido más profundo a nuestras vidas. La tragedia de lo sagrado es que 
él fácilmente puede convertirse en su contrario, en fanatismo, que nos cierra al mundo y nos retira la capacidad de respetar lo sagrado del otro, inclusive al punto de disponernos a eliminarlo para que él no nos incomode mostrando que otros mundos de la vida son posibles. En el mundo moderno, para que lo sagrado sea posible, es fundamental el respeto a la libertad individual y la posibilidad de cada uno tener sus creencias sin imponerlas a los otros.

Por lo tanto, el judaísmo secular no puede reducirse a los valores racionalistas y universalistas. Él debe ayudar a construir respuestas a los dramas subjetivos del individuo del siglo XXI. Debe producir nuevos drashot (interpretaciones) del judaísmo que den lugar a nuevas prácticas comunitarias. Querer hacer tabla rasa del pasado es una misión imposible y autodestructiva, y el sentimiento de judeidad del judío secular es siempre expresión de una voluntad de dar continuidad a un pasado, aunque sólo sea el de la familia. En ese sentido, todo judío es tradicionalista. La cuestión es el sentido que se da a esta tradición.

Para algunos, el judaísmo secular puede significar dar un formato diferente a algunas ceremonias, lo que es bienvenido y necesario, pero ciertamente él no puede transformarse en una nueva teología. Los judíos seculares no deben tener miedo de absorber elementos culturales del pasado, de acuerdo con afinidades individuales, sin que ello implique en un sentido literal. Quien hace la circuncisión en sus hijos o la ceremonia del bar/bat mitzva, generalmente lo hace como una forma de afirmar una tradición, y no porque crea que se trata de un mandamiento divino, o que a los 13 años (o a los 12 años, las niñas) los hijos realmente son responsables por sus actos. De la misma forma, rezar el Kadish Iatom en el entierro o aniversario del fallecimiento de un ser querido, en general, no significa que quien lo hace cree en su contenido (suponiendo que entienda su significado, básicamente un himno de alabanza a Dios), sino porque él fue recitado por sus padres, abuelos, bisabuelos y así sucesivamente. Es una forma de hacer contacto con una tradición, como puede ser recitar, en una ceremonia, el Shma Israel (oración que dice "Oye Israel, Dios es nuestro Dios, Dios es uno"). Son rituales que permiten una conexión con el pasado y con una colectividad de memoria.

Al mismo tiempo, se trata de superar frontal y abiertamente las categorías de puro/impuro en el tratamiento de los individuos y grupos.
Estos elementos presentes en la biblia y en el Talmud representan una ofensa a la sensibilidad humanista, que santifica el individuo y la vida, nunca identidades colectivas.

Esto no excluye el problema de la definición institucional de quién es judío. Todo grupo organizado define barreras de entrada bajo la forma de ritos de pasaje. El judaísmo talmúdico resolvió el problema, reduciéndolo a un destino biológico o a la aceptación de sus ritos de conversión. La visión de un judaísmo con fronteras claras dadas por la matrilinealidad, aunque desagrade a buena parte de los judíos seculares, produce un sentimiento de seguridad. Existe el miedo natural de implosión del "club". Las reglas de entrada existentes son malas pero aseguran el mantenimiento del orden conocido. Solo que mantener las ganancias secundarias producidas por las reglas de inclusión/exclusión talmúdica implica un costo por demás alto, pues las garantías de seguridad que ellas dan exigen empeñar y sacrificar valores humanistas.

Cada club tiene sus reglas de entrada. Y los viejos socios tendrán dificultad de aceptar nuevos criterios. Pero el judaísmo contemporáneo es un campo cultural, con fronteras porosas, y es bueno que así sea. Un rabino del movimiento conservador, Jack Wertheimer, anunció poco más de una década atrás que la decisión de la corriente reformista de aceptar la patrilinealidad dividiría el judaísmo. Afirmación que se mostró errónea. Para permanecer unido, el judaísmo deberá aceptar el mínimo y no el máximo denominador común.

Si el judaísmo se abre al mundo, ¿quién definirá quién es judío y quién no es? ¿Cómo sabemos si alguien es o no el parte del "club"? Creo que se trata de un falso problema, ciertamente en la diáspora, donde no se distribuye cédula de identidad o pasaporte identificando alguien como judío con derechos de ciudadanía.

La actitud negativa en relación al proselitismo es producto de una imposición exterior (la prohibición del clero católico y musulmán) transformada en virtud. Sufrimos del miedo de ser invadidos, como si la humanidad desease convertirse al judaísmo. No hay riesgo de invasiones masivas de personas que quieran definirse como judías. El judaísmo excluyente no garantizará el futuro del judaísmo, sólo garantiza la exclusión creciente de los judíos del judaísmo. 
El judaísmo secular debe asumir frontalmente la separación entre ser judío como hecho biológico y como opción cultural. El judaísmo talmúdico transformó el cuerpo del judío en puro y el del no judío en impuro. Cualquiera que hayan sido las justificativas, ellas son inaceptables en una perspectiva humanista.

La cuestión de la conversión se expone de forma diferente en Israel y en la diáspora. En Israel, ella define el derecho a la ciudadanía, movilizando intereses económicos y políticos que no existen en la diáspora. El interés del Estado de Israel ha sido de expansión demográfica, lo que ha llevado a practicar una política de aceptación extremamente amplia de emigrantes. El problema, como hemos visto, es que el emigrante posteriormente tiene dificultades por causa del poder del establishment religioso que define la nacionalidad que aparece en la cédula de identidad.

En la diáspora el 1 judaísmo humanista deberá expandir los ritos de judaización que no impliquen declaración de creencia religiosa. Así serán judíos aquellos que se identifican con el judaísmo, sea por nacimiento, tanto de padre o madre judía, o no judíos que decidieron casar con judíos y construir para los hijos una familia judía. Serán igualmente "naturalmente" judíos descendientes de aquellos que en algún momento del pasado fueron convertidos por la fuerza y hoy reivindican la identidad judía.

Esta visión, que está se imponiendo por la fuerza de los argumentos y de los hechos, produce la inseguridad en muchos, como en todo club cerrado al mundo exterior, celoso de limitar el número de sus miembros con derecho a poder reivindicar ser parte de la misma tribu de Einstein y Freud. Vivir como club exclusivo es cómodo, pero el precio es la extinción demográfica y el empobrecimiento cultural del pueblo judío.

Toda apertura presentará desafíos y podrá redefinir el judaísmo tal como lo conocemos. Sólo que esta redefinición ya está en curso, un judaísmo con múltiples faces e interfaces con el mundo, un espacio cultural más que un destino biológico al cual se está ligado por nacimiento, aunque el nacimiento en una familia de madre o padre judíos seguirá desempeñando un papel central, como en todas las identidades étnicas.

El problema práctico del judaísmo secular es expandir formas de organización colectiva, muchas de las cuales podrán ser hechas en conjunto con judíos religiosos humanistas, otras separadas, como sinagogas seculares, centros culturales, escuelas, cursos o Yeshivot seculares. Sin estas organizaciones, los judíos seculares continuarán rehenes de las diversas corrientes de judaísmo religioso para elaborar ritos de pasaje, (nacimientos, bar/bat-mitzvot, entierros, conversiones, festividades y conmemoraciones). Inclusive tenderá a ser cada vez mayor la presencia de rabinos seculares, ya que en el judaísmo el lugar del rabino era el de estudiar el judaísmo y orientar la comunidad, no un papel religioso. Existen hoy, en el mundo, varias iniciativas extremamente creativas, como el grupo YOK en Buenos Aires, el Centro Itzhak Rabin en Bruselas, el colegio Meitar y la yeshiva secular Bina en Israel, la Federación Internacional de Judíos Seculares y Humanistas, las sinagogas seculares fundadas por el rabino Sherwin Wine, revistas como Yahadut Jofshit y Contemplate y centros extremamente activos como el Centro de Comunitario de Judaísmo Laico, en Bruselas.

Un nuevo drash (interpretación) de la tradición judaica presenta enormes posibilidades de creatividad y renovación, parte de la cual inclusive está siendo hecha por rabinos reformistas y conservadores, pero que están limitados por el marco institucional. Tomemos por ejemplo el Yom Kipur, día del perdón. En él se pide disculpa a Dios por los actos errados cometidos. La idea de pedir perdón a Dios y que nos inscriba en el "libro de la vida" es infantil e inmoral. Infantil porque transferimos a una fuerza superior, a un padre poderoso, el poder de absolución y la responsabilidad última por nuestros actos. Inmoral porque suponemos, como en la confesión católica, que el mal cometido puede ser periódicamente borrado por un acto divino y no por nuestra acción reparadora. El Yom Kipur puede ser re-significado en un sentido de reorientación de nuestras acciones en relaciones a los otros y a nosotros mismos. Pues el principal personaje a ser perdonado en general somos nosotros mismos, por los sufrimientos que nos infringimos y por la culpa innecesaria que cargamos, inclusive la de vivir en un mundo con tanta injusticia y sufrimiento.

Igualmente, nuevas visiones de lo que sea kasher (puro) y treif (impuro), o de mitzva (mandamiento) pueden recrear estos términos para referirnos a las conductas que nos parecen éticamente correctas o no. De hecho, este tipo de significado es predominante en su uso popular, donde la mitzva se refiere a una buena acción, producto de la iniciativa personal y no un mandamiento u orden divina y treif a algo errado o ilegal. 
Las nuevas formas de celebrar el judaísmo se orientan crecientemente, en todas sus tendencias, en el sentido de ayudar a las personas a sentirse orgullosas de su judaísmo (jew is jewcy), en valorar la alegría y humor, en procurar en el pasado sabiduría para los tiempos inciertos. El judaísmo secular deberá aprender a celebrar la condición judaica como fuente de alegría, sin dejar de contener memorias de persecución y sufrimiento y valores de compasión y solidaridad.

Llevando en consideración las necesidades subjetivas individuales, la solidaridad frente a las persecuciones de judíos continuará siendo uno de los cimientos de la identidad judía. Pero el antisemitismo no puede continuar siendo presentado como un destino inexorable, ni ser asociado, implícita o explícitamente, a un discurso/sentimiento que separa de forma visceral el judío del no judío. Igualmente, la identificación con el destino del Estado de Israel continuará siendo uno de los pilares de la mayoría de los judíos seculares, pero esto no implica el apoyo ciego a sus gobiernos. Los judíos seculares pueden tener un papel importante en colaborar con los movimientos por la paz en Israel, inclusive criticando abiertamente la política externa y el apoyo incondicional dado por los líderes comunitarios a la política oficial de los gobiernos israelíes.

El judaísmo secular pos-moderno deberá ser capaz de valorar la positividad de la diáspora y de mantener la memoria del Holocausto, sin que ella se sustente en la paranoia y en la psicología del sobreviviente; de relacionarse a la tradición rabínica sin someterse a valores y prácticas anacrónicas; de justificar la voluntad de continuidad por la afirmación de sus tradiciones propias y no por el fantasma del antisemitismo; de elaborar la diferencia de forma no-xenofóbica; de conjugar destino y libertad, renovación y tradición. Decidir vivir el judaísmo humanista es una aventura individual y colectiva, sin garantías dadas por Dios.

¿Cómo y cuándo los judíos seculares volverán a producir movimientos sociales capaces de renovar el judaísmo? Las primeras generaciones de judíos seculares se construyeron como una reacción a los padres, que tenían como referencia un judaísmo ortodoxo, con valores rígidos que no respondían a los desafíos y expectativas del mundo moderno. Una buena parte de los jóvenes judíos seculares en la actualidad no tiene ninguna referencia clara del judaísmo a partir o contra la cual definir objetivos.
El proceso de reconstrucción del judaísmo secular y humanista no será obra de intelectuales individuales. En el mejor de los casos, su contribución será la de ayudar a quebrar los dogmas y camisas de fuerza que fueron relevantes para el judaísmo secular en el siglo $\mathrm{XX}$, pero que hoy son barreras para su desarrollo. Pero el nuevo judaísmo secular será una respuesta de las nuevas generaciones, con propuestas adecuadas a sus realidades. La generación que está saliendo de escena tiene la responsabilidad de apoyar y facilitar esta transición, pues si no tenemos un modelo claro para ofrecer, podemos trasmitir una cierta experiencia y conocimiento, aceptando que cada generación es responsable por lo que hace con su herencia. 


\section{ANEXOS: Textos sobre Pesaj y Yom Kippur}

\section{PESAJ}

Cada año festejamos Pesaj porque la libertad, para los individuos y para la sociedad, es siempre una travesía, nunca un punto de llegada, y ella sólo es posible porque se alimenta del ejemplo y de las luchas de las generaciones pasadas.

Pesaj es un momento de reflexión sobre lo que nos hace esclavos, permitiendo que la opresión se instale en nuestro interior y en nuestras relaciones. Por esto festejar la libertad exige reflexionar sobre la servidumbre, sobre el Faraón que cada uno lleva dentro de sí mismo.

- El Faraón que sólo se percibe a sí mismo.

- El Faraón que desea que los otros lo obedezcan.

- El Faraón que no acepta que cada persona es diferente.

- El Faraón que juzga antes de comprender.

- El Faraón que divide todo en correcto y equivocado.

- El Faraón que habla para no escuchar.

- El Faraón que teme ideas diferentes de las suyas.

- El Faraón que ríe de los otros sin ser capaz de reír de sí mismo.

- El Faraón que confunde solidez con rigidez.

- El Faraón que critica y no acepta ser criticado

Pesaj nos recuerda que el poder material, económico o político, no debe ser confundido con el poder de ser internamente libre. Porque la libertad no se compra ni se impone, sólo puede ser construida por cada uno y en la convivencia, inspirándose en ejemplos, pero siguiendo caminos que son siempre singulares. Por eso:

- Sólo la libertad nos lleva a valorar preguntas que cuestionan nuestras certezas y a dudar de respuestas que confirman nuestras creencias.

- Sólo la libertad nos permite amar nuestros seres queridos sin querer transformarlos en espejos de nosotros mismos.

- Sólo la libertad nos permite llevar la vida en serio, sin perder el humor.

- Sólo la libertad nos permite aprender nuevas ideas que cuestionan nuestras creencias.
- Sólo la libertad nos permite entender nuestros cambios y los de las personas que nos rodean.

- Sólo la libertad nos enseña que la vida nunca se reduce o puede ser contenida en leyes y conceptos aparentemente rigurosos.

- Sólo la libertad nos da el sentido de la ironía y del humor.

- Sólo la libertad nos permite entender que toda frontera usada para clasificar a los otros es precaria y que nunca debe ser transformada en una forma de descalificar.

- Sólo la libertad permite que la tradición sea una fuente de sabiduría y no una camisa de fuerza.

La afirmación de la libertad es un camino que exige rupturas y distanciamientos de un mundo conocido y aparentemente seguro. Pero nada puede eliminar la angustia ni las incertidumbres. O nos refugiamos en la repetición mecánica y en creencias ciegas que sofocan la curiosidad, huyen de lo desconocido y temen lo que está fuera de nuestro control, o las transformamos en una energía que nos impulsa a descubrimientos y que nos hace crecer, transformando la vida en un proceso de aprendizaje permanente.

Sólo podemos luchar contra la servidumbre si enfrentamos al opresor y al oprimido que cada uno de nosotros cargamos. Porque la esclavitud individual es producida por traumas que nos hacen inseguros y por miedos que nos paralizan y nos transforman en personas rígidas y oprimidas.

- Un oprimido que se esconde de sí mismo procurando ser igual a los demás.

- Un oprimido que transforma, por inseguridad, el amor en posesión.

- Un oprimido que odia lo que no controla y lo que no se ajusta a su voluntad.

- Un oprimido que huye del cambio, en lugar de enriquecerse con él.

- Un oprimido que teme el futuro y el pasaje del tiempo en lugar de vivirlo intensamente.

- Un oprimido que inferioriza a los otros para sentirse superior.

- Un oprimido que se refugia en grupos y comunidades alrededor de las cuales crea murallas que deshumanizan a los que se encuentran afuera.

La libertad personal sólo puede ser plenamente realizada en comunidades que permiten la expresión libre de cada individuo. Debemos, por lo tanto, luchar contra toda forma de opresión política y social. Porque el 
autoritarismo se alimenta del odio, estigmatiza a quien discrepa, transforma el opositor en enemigo y a los individuos en miembros de manadas. Recordando siempre que no hay comunidad donde no existe justicia social, pues la pobreza y la opresión generan sufrimiento, exclusión y desesperanza.

Porque aspiramos a ser libres, pero nunca nos desprenderemos totalmente de los deseos de opresión, recordamos las grandezas, no por eso despojadas a veces de debilidades, de nuestros antepasados. A todos ellos, y a todas las personas justas de todos los pueblos y culturas, que hicieron posible el que hoy podamos brindar a la vida y a la libertad:

Shejyanu, ve'quimanau ve'higuiyanu lazman haze Que vivimos, que existimos, que llegamos, a este momento.

\section{Yom Kippur \\ El dia en que suspendemos nuestro juicio}

Rosh Hashana es la experiencia colectiva del pasaje del tiempo y Yom Kippur es el día que procuramos entender lo que este pasaje significa para cada uno.

Rosh Hashana es sobre nuestro destino, pues el tiempo no para, y Yom Kippur es sobre la libertad, la posibilidad de ejercer nuestra capacidad de no juzgar.

El pasaje del tiempo, a pesar de lo que nos trae de pérdida y sufrimiento, nos abre la posibilidad de aprender cosas nuevas y expandir nuestros sentimientos, esencial para soportar nuestras limitaciones y crear un mundo mejor para nosotros mismos y para los otros.

Somos privilegiados por vivir una situación sin penurias materiales que nos posibilita múltiples formas de enriquecer nuestra percepción del universo: viajando, leyendo, amando, comiendo cosas gustosas, conociendo personas, oyendo música o mirando una obra de arte. Pero todas ellas son extremamente limitadas si permanecemos cerrados dentro de marcos estrechos de nuestros juicios sobre nosotros mismos y sobre los otros.

Pues quien juzga mal se ve a sí mismo, piensa que posee la verdad y excluye la posibilidad de otras formas de percepción de la realidad.

En la tradición talmúdica, Yom Kippur es el día en que Dios juzga a las personas, pero para judíos humanistas, como dice el significado de la palabra Kippur, es un día de reparación, de reconciliación.

Reparación y reconciliación sólo son posibles si dejamos de juzgar. Yom Kippur es, por lo tanto, el día en que suspendemos nuestro juicio.

Pues nada es más opresivo que depender del juicio de otro.

Y nada nos puede producir más sufrimiento que el juicio que realizamos sobre nosotros mismos.

Juzgar sin antes comprender es la forma más grave de ignorancia, pues, al ignorar al otro, quedamos encerrados en nuestro pequeño mundo. 
Juzgar sin antes reflexionar es miedo de que otro nos muestre aspectos que nos dejan inseguros en relación a nosotros mismos.

Yom Kippur es el día que recordamos que muchas veces juzgamos no en función de valores de justicia, sino porque nos desagrada que el otro sea diferente a nosotros.

Es el día en que hacer ayuno significa desintoxicarse de nuestros juicios apresurados. juzgar.

Es el día en que podemos perdonar y perdonarnos porque dejamos de

Es el día en que no hay expiación, pues no hay culpa.

Es el día en que no nos dejamos oprimir por la obsesión de dividir entre lo correcto y lo equivocado y procuramos comprender.

Es el día en que dejamos de culpar y culparnos para tener más compasión con nosotros y con los que son diferentes de nosotros.

Es el día en que no nos cerramos en sistemas rígidos que son siempre narcisistas y reconocemos que vivimos en una zona gris, porque nuestros sentimientos son complejos y el ser humano es finito.

Es el día en que aceptamos que no somos omnipotentes y debemos hacer elecciones frágiles entre valores, intereses y afectos conflictivos.

Es el día en que no hay correcto o equivocado, sino la afirmación del deseo de mejorar nuestra vida y la de los otros.

Es el día de comprensión, un día de tiempos mesiánicos.

\section{Rosh Hashana y Yom Kippur}

Tiempos mesiánicos

Porque Rosh Hashana marca el pasaje del tiempo y Yom Kippur nos interroga sobre el sentido de nuestra vida, recordamos que hay:

1. Tiempo de mirar hacia el futuro y tiempo de recordar nuestro pasado.

2. Tiempo de pensarnos como individuos y tiempo de pensarnos como comunidad.

3. Tiempo de realizar y tiempo de reflexionar.

4. Tiempo de estar solos y tiempo de estar juntos.

5. Tiempo de recordar y tiempo de olvidar.

6. Tiempo de dar y tiempo de recibir.

7. Tiempo de enseñar y tiempo de aprender.

8. Tiempo de vivir y tiempo de morir.

9. Tiempo de hablar y tiempo de callar.

10. Tiempo de creer y tiempo de dudar.

11. Tiempo de sentirse culpable y tiempo de perdonarse.

12. Tiempo de juzgar y tiempo de suspender el juicio.

13. Tiempo de entregarse y tiempo de apartarse.

14. Tiempo de reír y tiempo de llorar.

15. Tiempo de arriesgar y tiempo de ser prudente.

16. Tiempo de trabajar y tiempo de descansar.

17. Tiempo de sembrar y tiempo de cosechar.

18. Tiempo de ser orgulloso y tiempo de ser humilde.

19. Tiempo de estar alegre y tiempo de estar triste.

20. Tiempo de tener ilusiones y tiempo de perderlas.

21. Tiempo de esperar y tiempo de actuar.

22. Tiempo de amar sin ser amado y tiempo de ser amado sin amar.

Y que la sabiduría se encuentra en comprender que el tiempo es siempre uno, en el cual:

1. Nuestro pasado está siempre presente en nuestro futuro.

2. La comunidad debe ser formada por individuos libres y los individuos no olvidan que siempre son parte de comunidades.

3. Quien actúa debe reflexionar y quien reflexiona debe actuar.

4. Los muertos están vivos en nosotros y la vida no puede desconocer la muerte. 
5. Se aprende desaprendiendo y se enseña aprendiendo.

6. Paramos de hablar para oír y oímos para entender lo que hablamos.

7. La prudencia no debe eliminar nuestra disposición a arriesgar y el coraje debe ser responsable.

8. Quien recibió ya retribuyó y quien dio ya recibió.

9. Quien siembra cosechó y quien cosecha no deja de sembrar.

10. No podemos ser orgullosos si no somos humildes y somos humildes porque somos orgullosos.

11. Estamos solos cuando estamos juntos y estamos juntos cuando estamos solos.

12. Creemos sin dogmatismo y dudamos sin dejar de luchar por lo que creemos.

13. Lloramos de alegría y reímos para no llorar.

14. No hay culpa sin perdón, ni juicios que no sean cuestionables.

Porque el tiempo nos permite amar y aprender y ambos son el mayor don de la vida, agradecemos:

Shehejyanu, ve'quimanau ve'higuianu lazman haze Que vivimos, que existimos, que llegamos a este momento. 